\title{
WestVirginiaUniversity
}

THE RESEARCH REPOSITORY @ WVU

Graduate Theses, Dissertations, and Problem Reports

2006

\section{An economic valuation of improved water quality in Opequon watershed}

Matthew C. Benson

West Virginia University

Follow this and additional works at: https://researchrepository.wvu.edu/etd

\section{Recommended Citation}

Benson, Matthew C., "An economic valuation of improved water quality in Opequon watershed" (2006). Graduate Theses, Dissertations, and Problem Reports. 2447.

https://researchrepository.wvu.edu/etd/2447

This Thesis is protected by copyright and/or related rights. It has been brought to you by the The Research Repository @ WVU with permission from the rights-holder(s). You are free to use this Thesis in any way that is permitted by the copyright and related rights legislation that applies to your use. For other uses you must obtain permission from the rights-holder(s) directly, unless additional rights are indicated by a Creative Commons license in the record and/ or on the work itself. This Thesis has been accepted for inclusion in WVU Graduate Theses, Dissertations, and Problem Reports collection by an authorized administrator of The Research Repository @ WVU. For more information, please contact researchrepository@mail.wvu.edu. 


\title{
An Economic Valuation of Improved Water Quality in Opequon Watershed
}

\author{
Matthew C. Benson \\ Thesis submitted to the \\ Davis College of Agriculture, Forestry, and Consumer Sciences \\ at West Virginia University \\ in partial fulfillment of the requirements \\ for the degree of \\ Master of Science \\ in \\ Agricultural and Resource Economics
}

Alan R. Collins, Ph.D., Chair

Tatiana A. Borisova, Ph.D., Committee Member

Gerard E. D’Souza, Ph.D., Committee Member

Division of Resource Management

Morgantown, West Virginia

2006

Keywords: Total Maximum Daily Load, Contingent Valuation, Willingness-to-Pay, Grouped Tobit 


\section{Abstract \\ An Economic Valuation of Improved Water Quality in Opequon Watershed}

\section{Matthew C. Benson}

The Opequon watershed is in northern Virginia and the eastern panhandle of West Virginia. In both states, Opequon Creek is classified as impaired due to violation of the bacteria standard and the narrative General Standard. Both states are using Total Maximum Daily Load (TMDL) plans to improve water quality. As part of the TMDL process, a contingent valuation survey was developed which would measure the benefits of improved water quality in Opequon watershed. Five thousand surveys were mailed to households in West Virginia and Virginia. Median willingness-to-pay (WTP) values were estimated from grouped tobit models. For in-state water quality improvements, Virginia households were found to have an annual WTP of \$48 and West Virginia households were found to have an annual WTP of \$32. For out-of-state clean-up, households in both states were found to have a one-time WTP of $\$ 18$. Total benefits of improved water quality most likely range between $\$ 3.7$ and $\$ 5.1$ million. 


\section{Acknowledgments}

In the process of writing this thesis, I would like to acknowledge the many individuals who helped during this study. Participants within the study area as well as collaborating organizations and universities allowed this project to be a success. The Agricultural and Resource Economics Program and its personnel should also be acknowledged for their time and support.

Additionally, I would like to acknowledge funding sources for this study. Funds for this project were made available through the University of Maryland USDA-CSREES MidAtlantic Regional Water Program, from experiment station Hatch funds and by Tom Basden of the WVU Extension Service. Lastly, without the help of my committee chair and members, Dr. Alan Collins, Dr. Tanya Borisova and Dr. Gerard D'Souza respectively, this study would never have been completed. My committee's tireless efforts and invaluable knowledge have not gone unnoticed and are greatly appreciated.

Special thanks go to my family and friends. I love you. My friends pushed me to enroll in this program and my family pushed me to finish it. Without my parents, Richard and Karen, this accomplishment could not have been done. My two brothers, Eric and Brian, must also be acknowledged and thanked for their support.

I owe all of you a deep thank you. 


\section{Table of Contents}

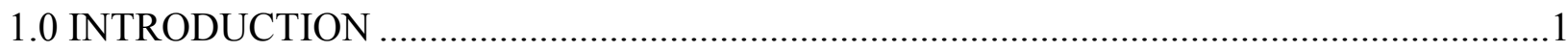

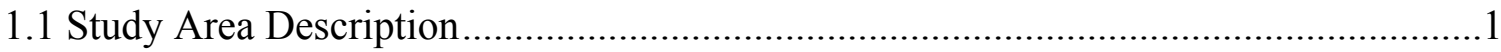

1.2 Background ......................................................................................................

1.2.1 The Clean Water Act and Total Maximum Daily Loads .................................4

1.2.2 Opequon Watershed Water Quality Problems ..................................................

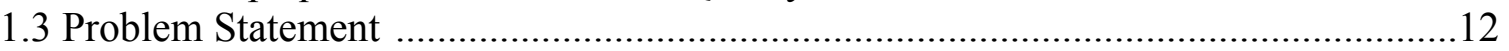

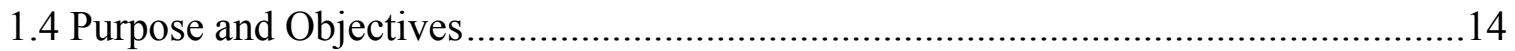

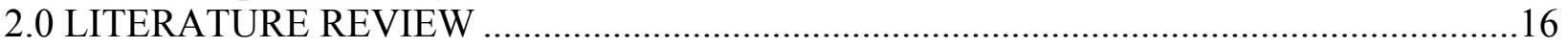

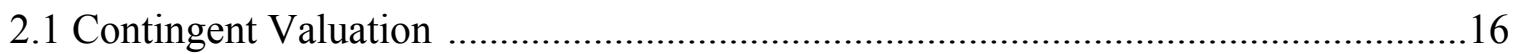

2.2 Theoretical Framework for Contingent Valuation.......................................................23

2.3 Water Quality Contingent Valuation Studies ……………........................................26

2.4 Aggregating Household Willingness-to-Pay ..............................................................33

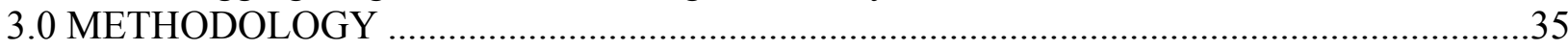

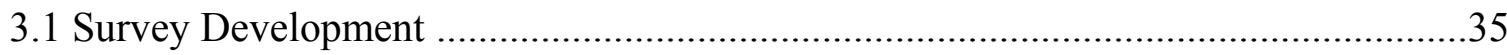

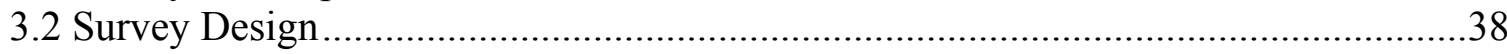

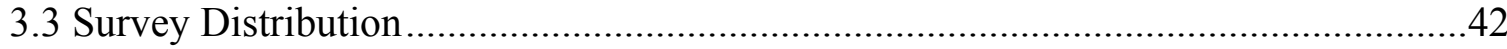

3.4 Empirical Model Specification ..........................................................................47

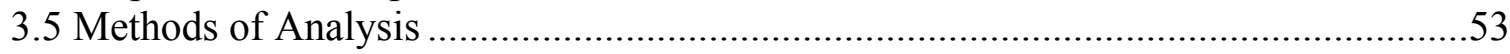

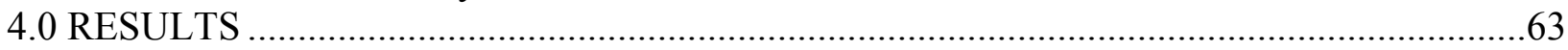

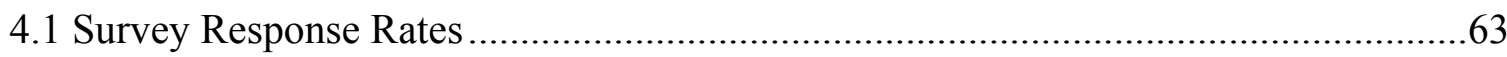

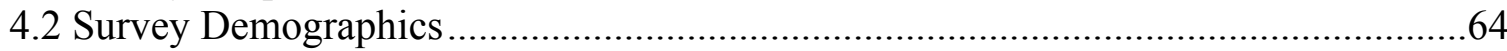

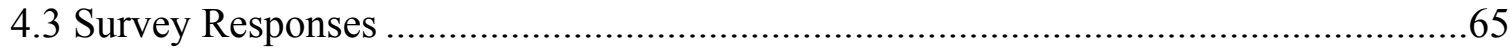

4.4 Household Results to Contingent Valuation Questions................................................70

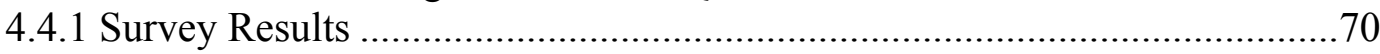

4.4.2 Grouped Tobit Model Results......................................................................75

4.5 Total Economic Benefits of Improved Water Quality ..................................................90

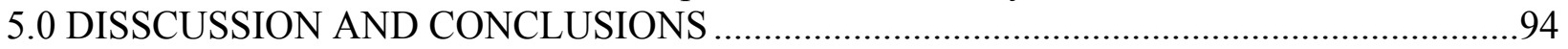

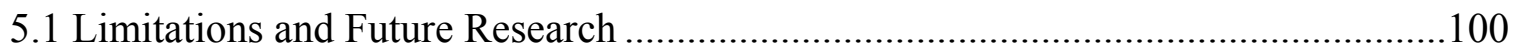

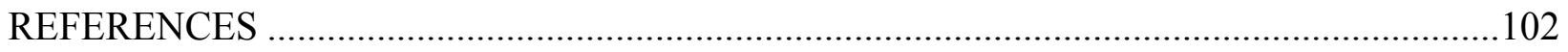

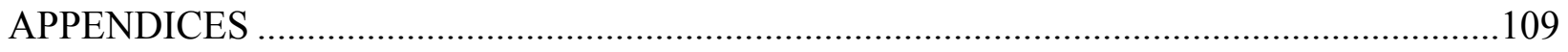

A.1 Contingent Valuation Surveys …………………..............................................109

A.1.1 West Virginia General Public Survey ..................................................109

A.1.2 Virginia General Public Survey ............................................................115

A.1.3 Virginia Riparian Landowner Survey .......................................................121

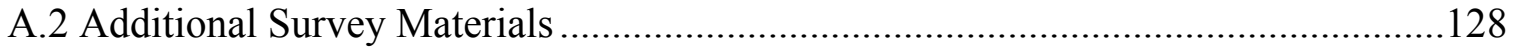

A.2.1 Cover Letter .....................................................................................128

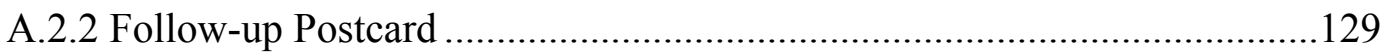

A.3 LIMDEP Final Grouped Tobit Estimation Results....................................................130

A.3.1 Comparing Sub-Samples: West Virginia General Public and

Virginia General Public WTP for In-State Clean-up ..........................................130

A.3.2 Virginia General Public WTP for In-State Clean-up Final Results ............133

A.3.3 Comparing Sub-Samples: Virginia General Public and Virginia

Riparian Landowner WTP for In-State Clean-up ................................................134 
A.3.4 Virginia Riparian Landowner WTP for In-State Clean-up Final

Results

A.3.5 West Virginia General Public WTP for In-State Clean-up Final

Results 138

A.3.6. Comparing Sub-Samples: West Virginia General Public and

Virginia General Public WTP for Out-of-State Clean-up

A.3.7 Pooled General Public WTP for Out-of-State Clean-up Final Results......142

A.4 Total WTP (Benefit) Estimates...

A.4.1- Summary of High Scenario Estimates...................................................... 143

A.4.2- Summary of Medium Scenario Estimates ...............................................143

A.4.3- Summary of Low Scenario Estimates......................................................143 


\section{List of Figures}

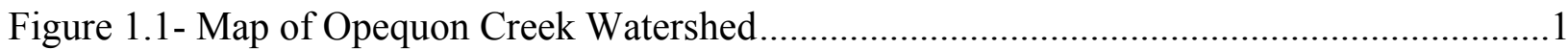

Figure 3.1 - West Virginia CV Question ..............................................................................

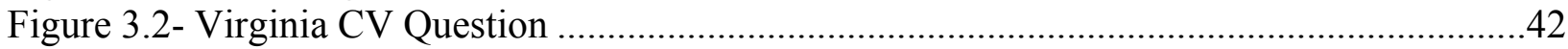

Figure 3.3- Map of the Sampled Zip Codes.................................................................................45

Figure 4.1- Distribution of monetary responses by WVGP respondents for In-state Clean-

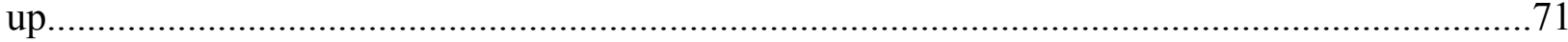

Figure 4.2- Distribution of reasons why Individuals in West Virginia Opposed or Remain Neural/Not Participate in Funding the In-state Clean-up .............................................................. 71

Figure 4.3- Distribution of monetary responses by VAGP respondents for In-state Clean-

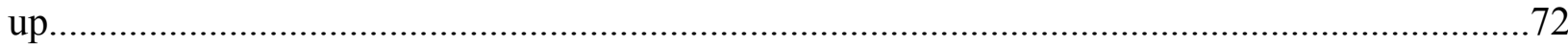

Figure 4.4- Distribution of reasons why Individuals in Virginia Opposed or Remain Neural/Not Participate in Funding the In-state Clean-up .73

Figure 4.5- Distribution of monetary responses by VARL respondents for In-state Clean-

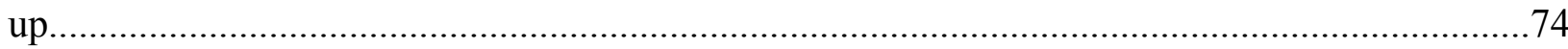

Figure 4.6- Distribution of reasons why Virginia Riparian Landowners Opposed or Remain Neural/Not Participate in Funding the In-state Clean-up ...............................................74 Figure 4.7- Total WTP for Water Quality Improvements in Opequon Watershed under the High Scenario.

Figure 4.8- Total WTP for Water Quality Improvements in Opequon Watershed under the Medium Scenario . .92

Figure 4.9- Total WTP for Water Quality Improvements in Opequon Watershed under the Low Scenario 


\section{List of Tables}

Table 2.1- Summary of Previous Water Quality CV Studies ..................................................26

Table 3.1- Summary of the Sample by Sub-sample ..............................................................43

Table 3.2- Summary of the Dates which Materials were mailed.............................................47

Table 3.3- Summary of Variable Names, Description and Coding .........................................52

Table 3.4- Summary of Discount Rates obtained through Energy related decision making .........57

Table 3.5- Summary of Scenarios to Reflect the Range of Aggregate WTP Possibilities. ...........59

Table 4.1- Summary of Survey Response Rates......................................................................64

Table 4.2- Summary of Comparing West Virginia Respondents to Census Data ........................64

Table 4.3- Summary of Comparing Virginia Respondents to 2000 Census Data .......................65

Table 4.4- Summary of Selected Questions from General Public Respondents..........................66

Table 4.5- Summary of Selected Questions from Virginia Riparian Landowner

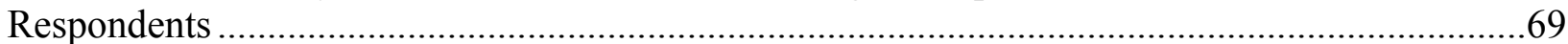

Table 4.6- Summary of Survey Monetary Responses by Sub-Sample and Clean-up Plan ...........75

Table 4.7- Summary of Grouped Tobit Model Results when comparing WTP for In-State

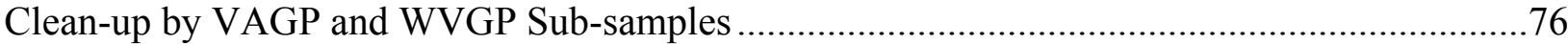

Table 4.8- Summary of Initial Grouped Tobit Model Results for WTP by VAGP

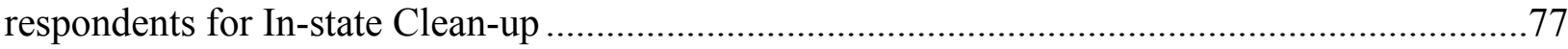

Table 4.9- Summary of Final Grouped Tobit Model Results for WTP by VAGP

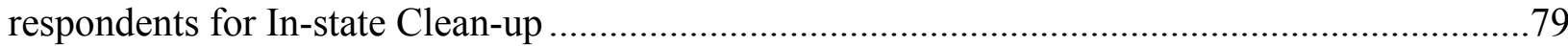

Table 4.10- Summary of Grouped Tobit Model Results when comparing WTP for InState Clean-up by VAGP and VARL Sub-samples ..............................................................8

Table 4.11- Summary of Initial Grouped Tobit Model Results for WTP by VARL respondents for In-state Clean-up ................................................................................ 81

Table 4.12- Summary of Final Grouped Tobit Model Results for WTP by VARL

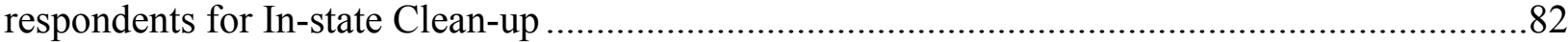

Table 4.13- Summary of Initial Grouped Tobit Model Results for WTP by WVGP

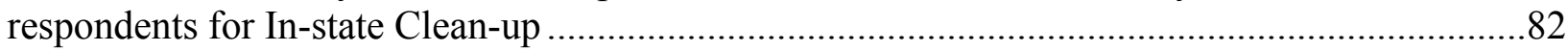

Table 4.14- Summary of Final Grouped Tobit Model Results for WTP by WVGP

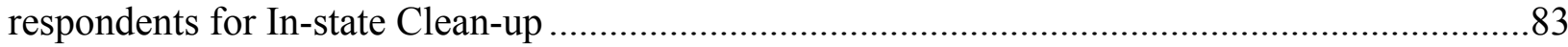

Table 4.15- Summary of Grouped Tobit Model Results when comparing WTP for Outof-State Clean-up by VAGP and WVGP Sub-samples .84

Table 4.16- Summary of Final Grouped Tobit Model Results for WTP by Pooled General

Public Respondents for Out-of-state Clean-up ...................................................................85

Table 4.17- Summary of Respondent Mean and Median WTP by Sub-Sample .......................87

Table 4.18- Summary of Non-Respondent Mean and Median WTP by Sub-Sample ..................89

Table 5.1- Summary of Variables found to be Statistically Significant in determining WTP for General Public Household .......................................................................................95

Table A.4.1 - Summary of High Scenario Total WTP Estimates ..............................................143

Table A.4.2- Summary of Medium Scenario Total WTP Estimates .....................................143

Table A.4.3- Summary of Low Scenario Total WTP Estimates.............................................143 


\subsection{Introduction}

This study, as well as the improvement of water quality within Opequon Creek watershed was undertaken as part of the Mid-Atlantic Regional Water Quality Coordination Project. This program is a partnership between the United States Department of Agriculture Cooperative State Research, Education, and Extension Service (USDA-CSREES) and land grant colleges and universities within the mid-Atlantic region (USDA-CSREES, 2006).

\subsection{Study Area Description}

The Opequon Creek watershed is located on the state border of northern Virginia and the eastern panhandle of West Virginia. ${ }^{1}$ This watershed lies in Jefferson and Berkeley counties of West Virginia and Frederick and Clarke counties of Virginia (Figure 1.1). The Virginia portion of the Opequon watershed is 97,000 acres in size and the West Virginia portion is 124,000 acres in total size. Opequon watershed drains $894 \mathrm{~km}^{2}$ (approximately 554 miles $^{2}$ ) of the northern Shenandoah Valley (Snyder et al., 2003).

\footnotetext{
${ }^{1}$ As defined in the TMDLs for Opequon watershed, a watershed is a drainage area or basin in which all land and water areas drain or flow toward a central collector such as a stream, river, or lake at a lower elevation.
} 


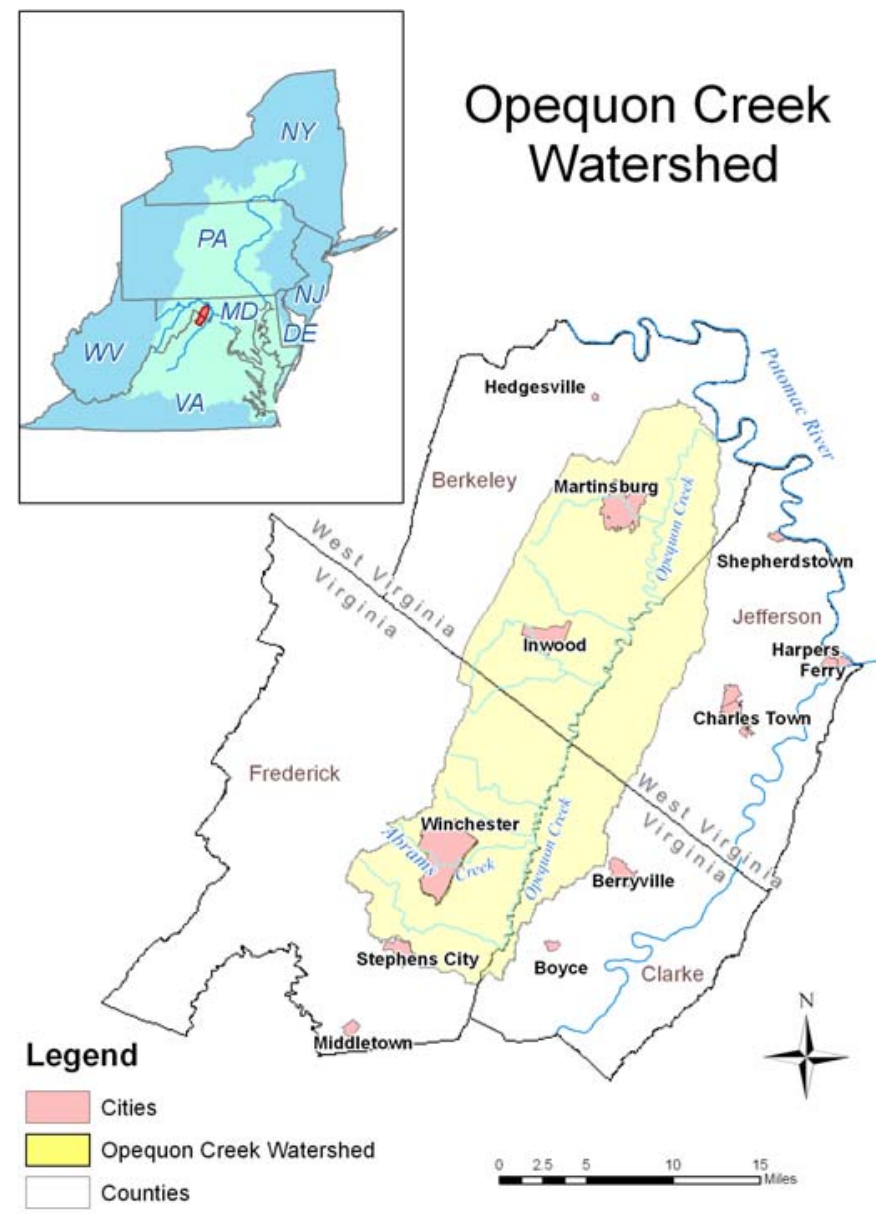

Figure 1.1- Map of Opequon Creek Watershed. *Produced by Dr. Tatiana Borisova Opequon Creek starts in southern Frederick County, Virginia and flows east then north, crossing over into West Virginia, before emptying into the Potomac River. In past studies, as well as for the purpose of this study, Opequon Creek is described in three segments; Upper, Lower and the West Virginia segment (VA DEQ, VA DCR and DBSE VT, 2003; VA DEQ, VA DCR and DBSE VT, 2004). The Upper segment of Opequon Creek starts at the creek's headwaters and ends at the confluence with Abrams Creek. Abrams Creek is a tributary of Opequon Creek and meanders through the city of Winchester. The Lower segment of Opequon Creek starts at the confluence with Abrams Creek and ends at the Virginia-West Virginia state line. The West Virginia segment is 
located between the Virginia border and the Potomac River. Sub-watersheds surround each respective portion of Opequon and Abrams Creeks.

In Virginia, Opequon Creek watershed is part of the Lord Fairfax Soil and Water Conservation District (LFSWCD). Part of the LFSWCD includes the city of Winchester as well as Clarke and Frederick counties (LFSWCD, 2006). The Upper and Lower Opequon watersheds are mostly agricultural land and Abrams watershed is mostly urban land (approximately 50\% respectively). The rest of the Upper Opequon watershed is divided between forest and urban land use, $33 \%$ and $14 \%$ respectively. The remainder of the Lower Opequon watershed is also comprised of forest and urban land, 29\% and 19\% respectively. The remainder of the Abrams Creek watershed is divided between forest and agricultural land, $22 \%$ and $27 \%$ respectively (VA DEQ, VA DCR and DBSE VT, 2003; VA DEQ, VA DCR and DBSE VT, 2004). Throughout Virginia portion of Opequon watershed, rapid growth and development is being experienced causing additional strains on environmental resources (LFSWCD, 2006).

In West Virginia, Opequon Creek is part of the Eastern Panhandle Conservation District (EPCD). ${ }^{2}$ The EPCD includes various watersheds that flow into the Potomac River. Within the EPCD, Opequon Creek is part of the Direct Drains watershed. The EPCD contains approximately $48 \%$ forested, $28 \%$ agricultural, $7 \%$ urban and $17 \%$ mixed open land, primarily characterized by broad level fertile valleys that are extensively farmed. The karst geology throughout much of the EPCD lends itself to rapid distribution of pollutants into groundwater and subsequently into surface waters from both urban and agricultural sources. In addition to this, development in the EPCD has sharply increased

\footnotetext{
${ }^{2}$ As defined in West Virginia's Potomac Tributary Strategy, conservation districts are chartered legal subdivisions of State government and a universal unit of government in every state.
} 
because of its close proximity to the Washington-Baltimore Metropolitan Area and is the fastest growing region within the state of West Virginia (West Virginia Potomac Tributary Strategy, 2005).

\subsection{Background}

\subsubsection{The Clean Water Act and Total Maximum Daily Loads}

The Clean Water Act of 1972 is the foundation of surface water quality protection in the United States (U.S.) (US EPA, 2003). Its objective is to restore and maintain the chemical, physical, and biological integrity of the nation's waters (US EPA, 2006d). High quality surface waters support a variety of economic services including healthy aquatic

ecosystems, flood control, erosion control, recreational swimming and fishing and nature observation (Bergstrom, Boyle and Poe, 2001). The Clean Water Act has given the Environmental Protection Agency (EPA) the authority to implement pollution control programs (US EPA, 2006a).

When Congress passed the Clean Water Act, it declared a national goal of the elimination of the discharge of all pollutants into the navigable waters of the U.S. by 1985. An interim goal was established to provide the protection of fish, shellfish and wildlife and recreation by July $1^{\text {st }}, 1983$ (US EPA, 2006d). As described by Carson and Mitchell (1993), who reference Leone and Jackson (1981), because the benefits from these goals were thought to be large, and the costs were mostly unknown, Congress paid little attention to the costs. However, these goals for years 1983 and 1985 have yet to be met. As of $2000,33 \%$ of U.S. waters were examined and $40 \%$ of streams, $45 \%$ of lakes and $50 \%$ of estuaries were not clean enough to support uses such as fishing and swimming (US EPA, Office of Water, 2002). The EPA asserts that the leading 
contaminants in assessed waters include bacteria, metals, excess nutrients and siltation (sediment). Additional causes of impairment are said to be runoff from agricultural lands, municipal point sources and hydrologic modifications.

Congress has postponed compliance deadlines and has enacted new requirements for state programs to deal with non-point sources of pollution (Cason and Mitchell, 1993). From this, the Clean Water Act has evolved from a source-by-source, pollutantby-pollutant approach to a watershed-based strategy approach. Under this new approach, equal emphasis is placed on protecting healthy waters and restoring impaired ones. This approach is also based on the involvement of stakeholder groups in the development and implementation of strategies for achieving and maintaining state water quality goals (US EPA, 2003).

Opequon Creek is listed as impaired according to the standards of the Clean Water Act in both states. However, the process of improving water quality is in different stages in the states of Virginia and West Virginia. Under Section 303(d) of the Clean Water Act, States are required to develop a list of impaired waterways in the state. This list is often referred to as the 303 (d) list. Waterways are determined to be impaired if they do not meet state water quality standards (US EPA, 2005a). In other words, a water quality "impairment" is said to exist if a body of water does not support its designated uses. In the state of Virginia, water quality standards specify that surface waters are designated for "recreational use" (e.g. swimming, fishing and boating) and "aquatic life use" (e.g. viable fish populations) (Benham, Walker, Yagow, 2003). Once a waterway is determined to be impaired, the process of creating a Total Maximum Daily Load

\footnotetext{
3 To support "recreational use", Virginia has set a number for the maximum amount of bacteria that can be found in a waterway and still be safe. If this criterion is violated, the body of water is said to have bacteria impairment (Benham and Zeckoski, 2005).
} 
(TMDL) must begin (US EPA, 2005a). State and federal water quality management, protection and restoration efforts are linked together through the implementation of a TMDL (UVA IEN, VA Tech Center for Economic Education and VA Department of Forestry). The process of TMDL implementation is one method to achieve water quality improvements.

A TMDL is a written plan that specifies the maximum amount of pollution that a water body can receive and still meet water quality standards (US EPA, 2005b). An implementation strategy, should be completed once a TMDL study has been conducted. A TMDL Implementation Plan (IP) describes the actions (e.g. best management practices) to implement the allocations contained in the TMDL study. The main objective of a TMDL IP is to restore water quality within the study area (Commonwealth of Virginia, 2003). Although TMDLs have been required by the Clean Water Act since 1972, it is not until recently that states have developed them (US EPA, 2006b).

Nationwide, the EPA is under court ordered consent decrees to ensure that tens of thousands of TMDL plans are developed in the next ten to fifteen years. Total costs of this are estimated to range between $\$ 15$ and $\$ 66$ billion (Barham, Zeckoski and Benham, 2004). In 1991, the state of Virginia began submitting its list of impaired waterways to the EPA. In 1998, the American Littoral Society (ALS) and the American Canoe Association (ACA) sued the EPA on the basis that Virginia was failing to clean-up its impaired waters. The court rule in favor of the ALS and ACA and Virginia agreed to begin implementation of TMDLs for waters listed as impaired as of 1998. Virginia had listed 600 water bodies as impaired as of 1998, and must develop 665 TMDLs by the year 2010 (UVA IEN, VA Tech Center for Economic Education and VA Department of 
Forestry). Shifting to West Virginia, in 1997, the EPA began developing TMDLs for water bodies within this state because West Virginia did not have the resources to develop them. However, in 2004, West Virginia was in position to the take over the process of creating and implementing TMDLs, largely due to the efforts of stakeholders throughout the state (Barham, Zeckoski and Benham, 2004).

\subsubsection{Opequon Watershed Water Quality Problems}

Opequon and Abrams Creeks are listed as impaired due to bacteria and benthic impairments. Benthic impairment refers to violations of the narrative General Standard (VA DEQ, VA DCR, DBSE VT, 2003). Bacteria impairment refers to violations of the bacteria standard. Benthic organisms are invertebrates living in or on the bottom of a water body that are visible without a microscope. To support "aquatic life use", biologists take benthic macro-invertebrate surveys of the body of water in question and compare them to benthic macro-invertebrate surveys from a reference site that has similar characteristics. In the case of Opequon Creek, biologists used Upper Opequon Creek as the reference site for this analysis (VA DEQ, VA DCR, DBSE VT, 2003). When it is determined that the benthic environment does not meet the "aquatic life use" goal, the body is deemed as having a benthic impairment (Benham, Walker, Yagow, 2003).

As discussed in the TMDL studies for Opequon watershed, throughout the initial stages of TMDL development in Virginia, public participation was elicited at several public meetings (VA DEQ, VA DCR and DBSE VT, 2003; VA DEQ, VA DCR and DBSE VT, 2004). These meetings were held in 2003 at a local venue within the watershed. Stakeholders attended these meetings to help guide the TMDLs, as well as to receive input about their progress. Public participation has also been a major part of 
developing an IP to improve water quality in this watershed. IP meetings were held to elicit feedback and update stakeholders of the progress made. Public meetings discussing the IP were held throughout 2005 and have continued through 2006. Because of these public meetings, citizens living in the Virginia portion of Opequon watershed should have a greater awareness, knowledge and understanding of the water quality problems within their state's portion of the watershed, compared to West Virginia residents. Before the TMDLs were developed, biological monitoring was needed and performed to assess the water quality problems in Opequon watershed. To assess the benthic impairment, biological monitoring was performed by Virginia Department of Environmental Quality (VA DEQ). In the Abrams Creek watershed, biological monitoring occurred from October 1994 to October 2001 at a specified benthic monitoring site. During this period, all seven benthic samples were rated as "moderately" impaired. Biological monitoring was also performed by VA DEQ in the Lower Opequon Creek watershed from October 1994 to May 2002 at the specified benthic monitoring site. During this period, seven of the nine benthic samples were rated as "moderately" impaired, with the remainder receiving a rating of "slightly" impaired. Because of these observations, Lower Opequon and Abrams Creeks are classified as having a benthic impairment and are in violation of the narrative General Standard. Lower Opequon is listed as impaired for a stream length of 8.82 miles while Abrams Creeks is listed as impaired for a stream length of 10.8 miles (VA DEQ, VA DCR and DBSE VT, 2003).

The pollutant causing a benthic impairment was not implicitly identified because this impairment is based on biological inventory rather than on physical or chemical water quality standards. Instead, the most probable stressor creating this impairment was 
determined. As described in the TMDL, analyses of physical, chemical, biological, and observational data indicate that sediment was the most probable cause of the benthic impairments in both Lower Opequon and Abrams Creeks. It is believed that sediment is delivered to these creeks through the processes of surface runoff, channel and stream bank erosion, and from point source inputs. In addition to this, it is believed that background geologic forces have contributed to sediment deposition. However, natural sediment generation could have been accelerated through human-induced land-disturbing activities related to a variety of agricultural, forestry, and urban land uses (VA DEQ, VA DCR and DBSE VT, 2003).

The Virginia Department of Conservation and Recreation (VA DCR) has assessed the Abrams Creek watershed as having a high potential for non-point source pollution from urban sources. At the Abrams Creek watershed outlet, 58 water quality samples were collected from July 1992 through June 1997 (the 1998303 (d) 5-year listing period) A total of $17 \%$ exceeded the instantaneous standard. ${ }^{4}$ Consequently, Abrams Creek was assessed as not supporting the Clean Water Act's swimming use support goal and was included in the 1998 303(d) list for violation of the bacteria standard. The bacteria impairment in Abrams Creek starts at the headwaters and continues downstream to its confluence with Opequon Creek for a total of 10.8 miles long (VA DEQ, VA DCR and DBSE VT, 2004).

The VA DCR has assessed the Upper and Lower Opequon watershed as having a high potential for non-point source pollution from agricultural sources. The VA DEQ monitored pollutant concentrations by collecting 58 water quality samples between July

\footnotetext{
${ }^{4}$ The instantaneous standard specifies that fecal coliform concentration in the stream water shall not exceed 1,000 colony forming units per $100 \mathrm{~mL}(\mathrm{cfu} / 100 \mathrm{~mL})$.
} 
1992 and June 1997 at the Upper Opequon outlet. Of the samples collected, 19\%

exceeded the instantaneous standard. The VA DEQ also monitored pollutant

concentrations at the Lower Opequon outlet by collecting 59 water quality samples.

These samples were also collected between July 1992 and June 1997. Of these samples

collected, $12 \%$ exceeded the instantaneous standard. Because of these observations, Upper and Lower Opequon Creek was assessed as not supporting the Clean Water Act's swimming use support goal and was included in the 1998 303(d) list for violation of the bacteria standard. The bacteria impairment in Upper and Lower Opequon Creek starts at the creeks headwaters and continues downstream to the Virginia-West Virginia state line for a total of 33.7 miles (VA DEQ, VA DCR and DBSE VT, 2003; VA DEQ, VA DCR and DBSE VT, 2004).

The bacteria water quality impairment in Opequon watershed is said to pertain to fecal coliform. In this watershed, there are two significant point sources and 43 smaller sources permitted to discharge fecal coliform. However, the majority of the fecal coliform load originates from non-point sources. In Lower and Upper Opequon watershed, non-point sources of fecal coliform are said to be primarily from agricultural land and practices. In Abrams watershed, non-point sources include fecal coliform deposited directly on pastures and those land uses grouped under the residential land use category. Other sources of fecal coliform originate from wildlife and non-agricultural, non-point sources such as failing septic systems and pet waste (VA DEQ, VA DCR and DBSE VT, 2003; VA DEQ, VA DCR and DBSE VT, 2004).

TMDL standards for the bacteria impairment in Opequon watershed were developed using a modeling process which employed the Hydrologic Simulation Program 
- FORTRAN. This approach is in contrast to obtaining TMDL standards for benthic impairments which used the reference watershed approach. However, modeling was also done for the benthic impairment by comparing both sets of impaired and referenced watersheds using the Generalized Watershed Loading Function (VA DEQ, VA DCR, DBSE VT, 2003; VA DEQ, VA DCR, DBSE VT, 2004).

Shifting the attention to West Virginia, water quality containments, as well as the causes of these containments have yet to be fully examined or quantified within this portion of Opequon watershed. Geographic and development issues have increased the awareness and concern over water quality within the West Virginia portion of Opequon watershed. Contributing to this increased awareness is the fact that the Potomac River empties into the Chesapeake Bay (the Bay). The Bay is a national and local treasure that contributes to the livelihood, recreation and cultural heritage of the region (West Virginia Potomac Tributary Strategy, 2005). The states surrounding the Chesapeake Bay have determined that substantially reducing the flow of nutrients and sediment to the Bay will restore the Bay's health. The state of West Virginia has agreed to develop goals and objectives to reduce nutrient and sediment loads (West Virginia Potomac Tributary Strategy, 2005).

Through the use of a decision matrix at a Potomac Tributary Stakeholders meeting in September 2004, Opequon Creek was determined to be the number one priority creek for clean-up within the Potomac Basin. In the decision matrix, "stakeholders" were asked to assign values to various watersheds within the EPCD. Weighted and un-weighted values were calculated with Opequon Creek receiving the greatest scores for both (US EPA, Region III). From this, the Opequon Creek Project 
Team was established in April 2005 to discuss water quality issues pertaining to Opequon Creek in West Virginia. The purpose of this team is to, "undertake projects that will lead to reduction in pollutants entering Opequon Creek and its tributaries in West Virginia."

Water quality concerns have led the West Virginia Department of Environmental Protection to work with the EPA and other stakeholders to assure the completion of TMDLs for the West Virginia portion of Opequon Creek. Currently, Opequon Creek is listed as an impaired waterway in West Virginia due to violation of bacteria standards, the narrative General Standard and metals (aluminum) (US EPA, 2006c). A TMDL study is currently in the process of being developed for this portion of the watershed and is scheduled for completion by the end of 2006. Once a TMDL study has been developed and approved by the EPA, a TMDL IP can be completed.

\subsection{Problem Statement}

Within this region of the U.S., local and state governmental districts rarely coincide with watershed boundaries. Because of this, it is necessary to develop approaches that integrate water quality efforts on a watershed basis and cross political boundaries. The Chesapeake Bay Program (CBP) has accomplished this to an extent within this area. However, state programs and policies are usually developed and implemented independently within the CBP (USDA-CSREES, 2006). For example, states are independently focused on developing TMDL plans to achieve water quality standards for water bodies within their own boundaries (US EPA, 2006a).

Although the Opequon watershed is a continuous drainage area in which all of the land and water areas drain toward Opequon Creek, state standards require that the TMDL studies and IPs be developed independent of one another (US EPA, 2006a). In Virginia, 
TMDL studies have been completed for creeks within Opequon watershed and a TMDL IP is being finalized. In West Virginia, TMDLs are continually being developed for Opequon Creek, with a TMDL IP to be developed sometime in the future. Because Opequon Creek watershed is on the state boarders of Virginia and West Virginia, a multidisciplinary, multi-state approach is perhaps the most appropriate method to improve its water quality. The Mid-Atlantic Regional Water Coordination Project enabled the use of this approach by facilitating a working relationship between state and local governmental agencies, area stakeholders and landowners, local citizens and watershed organizations and three land-grant universities (West Virginia University, Virginia Tech and the University of Virginia). Across state lines, these entities had a broad, overarching goal of improving water quality within Opequon Creek watershed.

Descriptions surrounding the benefits of improved water quality are to be included in TMDL IPs (Commonwealth of Virginia, 2003). Because of this, the benefits of improved water quality within Opequon watershed will be discussed in the state of Virginia's TMDL IP as well as the state of West Virginia's IP. To provide a model by which this and other TMDL IPs can estimate monetary benefits through additional public involvement, a contingent valuation (CV) study will be conducted. CV is a survey based method that can place actual dollar benefit estimates on a change in a public good (i.e. improved water quality) through obtaining a household's willingness-to-pay (WTP). Unlike traditional environmental improvement projects where public involvement is mostly limited to meetings and review of documents, $\mathrm{CV}$ allows for greater public participation by conducting a survey. Increased public participation during the TMDL 
process should lead to a more effective method of achieving TMDL water quality standards.

From this type of survey work, random households within the Opequon watershed will be able state their WTP for improved water quality. These monetary responses will directly influence aggregate economic benefit estimates for improved water quality within this watershed. These responses will indirectly determine the expected level of benefits received from successful TMDL implementation. In addition, households throughout the watershed will be able share their opinion about Opequon watershed including water quality concerns and potential improvement projects. Knowledge of, and monetary values for, the benefits of improved water quality will be useful for those individuals executing the TMDL IP. Estimating benefits from an improvement in water quality in a local setting will provide the community and stakeholders' valuable information regarding the importance of improved water quality within these creeks and watershed. Methods and results of this project should also provide a refined framework by which other states and organizations can more effectively develop TMDL studies and implement them to meet their state water quality standards.

\subsection{Purpose and Objectives}

The purpose of this study is to estimate the monetary benefits of improved water quality within Opequon watershed so that they can be included in the TMDL IP for the Virginia portion of this watershed. In an economic valuation, the water quality 'commodity' to be valued is some change in economic services brought about by a change in water quality (Bergstrom, Boyle and Poe, 2001). An ancillary purpose of this study is to facilitate additional public participation in the development of the TMDL IP 
for Opequon watershed. Public participation was sought throughout the watershed at nearly every stage of developing the TMDL IP, and will indirectly be shown to be a critical component of this project.

The general objective of this study is to provide monetary value estimates for the expected outcomes of TMDL implementation. In the process, the author seeks to determine the factors that help explain an individual WTP for TMDL implementation within Opequon watershed.

The specific objectives are:

1. To determine an aggregate monetary value from the benefits of improved water quality within Opequon watershed.

2. To determine which characteristics (variables) are statistically significant in determining WTP for improved water quality within Opequon watershed. 


\subsection{Literature Review}

This review of literature will focus on a variety of areas with regard to topics

related to this study. First, contingent valuation (CV) will be explained. Background will be given related to $\mathrm{CV}$, along with addressing its validity, strengths and weaknesses. Second, the theoretical framework for CV studies will be detailed. This will lay the foundation by which welfare estimates can be linked to a household willingness-to-pay (WTP). In addition, previous similar CV water quality studies will be summarized. These studies were selected because they used CV to estimate an individual WTP for improved water quality within a body of water. Finally, aggregation scenarios of total benefit estimates will be described.

\subsection{Contingent Valuation}

The regulations for cost and damage recovery under the federal superfund program explicitly recognize the use of $\mathrm{CV}$ as a tool for establishing the non-market value of goods and services (Congressional Research Service, 1999). CVs are used to estimate economic values for all types of ecosystem and environmental goods and services (King and Mazzotta, 2005). Such ecosystem and environmental amenities are known as public goods. Mitchell and Carson (1989) define a public good as a good characterized by the conditions of non-excludability and non-rival congestion between individuals who wish to use that good. The first identified description of $\mathrm{CV}$ can be found in an article published by S.V. Ciriacy-Wantrup in 1947. However, CV was not used until 1963 in a $\mathrm{PhD}$ dissertation by Robert Davis (Congressional Research Service, 1999). Since then, CVs have been used in over 2,000 studies (Carson, 2000). Three noteworthy cases where CV was used include: the valuation of air quality improvement at the Grand 
Canyon; the valuation of damages resulting from the Exxon Valdez oil spill in Alaska; and the valuation of benefits from altering Glen Canyon dam operations (Congressional Research Service, 1999).

$\mathrm{CV}$ can be used to estimate use and non-use values and is the most widely used valuation technique to estimate non-use values. Non-use values are those such as existence, bequest and option values (King and Mazzotta, 2005). CV is a survey based method which places monetary values on public goods not bought and sold in a traditional market. A CV survey describes scenarios that offer different governmental actions. Survey respondents are then asked to state their preference concerning the described actions (Carson, 2000). Stated preference methodology refers to survey-based studies where respondents are asked questions that are designed to reveal information about their preferences or values (Freeman, 2003). CV is a direct measurement for a hypothetical market (Congressional Research Service, 1999). Typically, CVs are used to estimate social benefits resulting from improvements in the quality of non-marketed environmental goods, such as water quality improvements, which are of direct use to the consumer (Brox, Kumar, Stollery, 2003). Responses are then analyzed to derive economic values. A random assignment of prices allows the researcher to derive the WTP for that good (Carson, 1999).

CV has both strengths and weaknesses. Strengths include its ease of flexibility; it's easily understood by users and its ability to value multiple destination recreation trips (King and Mazzotta, 2005). In addition to this, CV is said to be the most widely accepted 
method for estimating total economic value, which includes non-use or passive-use values (King and Mazzotta, 2005). ${ }^{5}$

A few CV studies (Carson, Hanemann, and Mitchell, 1987; Polasky, Gainutdinova and Kerkvliet, 1996) have compared survey estimates to a vote on actual binding referendums and found the two to be quite similar (Carson, Groves and Machina, 2000). In addition to this, a large body of evidence exists that polling on referendum suggests that surveys taken close to an election generally provide a good prediction of actual referendum votes (Carson, Groves and Machina, 2000). Carson et al. (1996) compared $\mathrm{CV}$ and revealed preference (RP) methodologies by examining estimates for quasi-public goods. These authors examined 83 studies, containing $616 \mathrm{CV} / \mathrm{RP}$ comparisons for quasi-public goods. They found that $\mathrm{CV}$ estimates were smaller but not extremely smaller than their RP counterparts (Carson et al., 1996). However, these authors admit that some CV estimates exceeded their RP counterparts. Finally, Carson et al. (1996) state that arbitrarily discounting CV estimates because of their methodology appears to be unwarranted.

Controversies or weaknesses regarding CV are also described throughout the literature (Blamey and Bennett and Morrison 1999; Dalton, at al., 1998; Diamond and Hausman, 1994; and King and Mazzotta, 2005)). The objective here is not to dispel the validity of $\mathrm{CV}$, but to acknowledge research surrounding its limitations. Diamond and Hausman (1994) believe that CV is a deeply flawed methodology when measuring nonuse values. Dalton et al. (1998) cite various types of survey biases as a weakness of CV. These authors claim that biases may stem from its hypothetical nature, individual's strategic behavior and incentives, and information presented in the survey. Some

\footnotetext{
${ }^{5}$ Passive-use values are also known as existence values (Carson, 2000).
} 
researchers argue that there is a fundamental difference in the way people make hypothetical decisions as opposed to actual decisions (King and Mazzotta, 2005). In addition to this, Blamey, Bennett and Morrison (1999) assert that some researchers have speculated that "yea-saying" has played a role in their studies (McFadden and Leonard, 1993; Boyle et al., 1993; Ready, Whitehead and Blomquist, 1995). Mitchell and Carson (1989, 240-241) define "yeah-saying" as, "the tendency of some respondents to agree with an interview's request regardless of their true views." However, "yeah-saying" seems more likely in personal interviews, than with mail questionnaires. Blamey, Bennett and Morrison (1999) state that recent CV studies have provided estimates of WTP exceeding those found in experimental or real-life markets. Additional studies also found that CV results are not satisfactory predictors of actual donations (Champ et. al., 1997; Cummings, Harrison, and Rutstrom, 1995; Duffield and Patterson, 1991; Loomis et al., 1996; Navrud, 1992; Seip and Strand, 1992). Lastly, Diamond and Hausman (1994) describe two effects found in CV such as the "embedding effect" or the "warm-glow effect."

The "embedding effect" refers to the tendency of WTP responses to be similar across different surveys when theory suggests that they should be different. This is thought to arise from the failure of respondents to consider their budget constraint and from the non-existence of individual preferences for the public good in question (Diamond and Hausman, 1994). These authors give an example of this effect by describing WTP for clean-up of one lake to be approximately equal to WTP responses for the clean-up of five lakes, including the one asked about individually. The "warm glow effect" is thought to stem from respondents expressing their feelings about the scenario or 
valuation exercise itself. Respondents may feel good or derive moral satisfaction from the act of giving for a social good although they believe the good or improvement itself is unimportant (King and Mazzotta, 2005). The "warm-glow effect" could cause WTP to be inaccurate, creating an upward bias or an overvaluation of the improvement. Even with these controversies or weaknesses, Portney (1994) claims that it seems inevitable that CVs will play a role in public policy formulation. Portney (1994) also acknowledges that regulatory agencies and governmental offices responsible for natural resource damage assessment are making increased use of CV.

General survey work has additional weaknesses regarding its methodology. One weakness of survey work is the possibility of high non-response rates. Moore and Tarnai (2002) reference Armstrong and Overton (1977) when asserting that mail surveys have been faulted for their high non-response rates. Survey non-response can occur two ways. Unit non-response occurs when a sampled unit does not respond to the request to be surveyed. Item non-response occurs when the sampled unit fails to respond to a particular survey question (Dillman et al., 2002). Although a variety of additional errors could stem from general survey work, these two could be troublesome when using a mail questionnaire.

Dillman et al. (2002) assert that the causes of non-response remain constant irregardless of the survey mode. These authors cite the causes of non-response are a failed request, refusal to participate and incapacity to participate. However, depending on the type of survey (mail, web, telephone, or face to face), examples of survey nonresponse vary. Examples of these causes when using a mail questionnaire include the non-delivery of a survey, the mailing was read but ignored or illiteracy. The effect of 
survey non-response may lead to biases in point estimators and inflation of the variances of point estimators (Dillman et al., 2002).

Several survey design features can be used to help diminish survey non-response. For mail questionnaires, these features include acknowledging the agency that is completing the data collection, providing an advanced warning of the survey request, providing an incentive and using follow-up procedures to influence or persuade the individual to complete the questionnaire (Dillman et al., 2002). In addition to these distribution practices, Moore and Tarnai (2002) state several methods to analyze mail survey data once a high non-response rate has occurred. These methods include measuring the direction and magnitude of the non-response error and using weighted approaches to compensate for this as well as describing the characteristics of nonrespondents and comparing early and late respondents (Moore and Tarnai, 2002). Moore and Tarnai (2002) reference Cameron, Shaw and Ragland (1999) when stating there are methods to statistically model non-response error for mail survey data.

The validity of a measure is said to be the degree by which it measures the theoretical construct under investigation (Mitchell and Carson, 1989). Ideally, it would be best to assess the validity of a stated preference technique by comparing it with the true measure (Freeman, 2003). However, obtaining a true measure for the total economic benefits of environmental improvements is difficult. Difficulty of this lies in the fact that water quality is a public good. Because of this, content and construct validity must be employed to test the validity of measurement. Content validity is the extent to which the design and implementation of the survey conform to the generally recognized best 
practices. Construct validity examines whether $\mathrm{CV}$ responses are related to variables that economic theory suggests should be predictors of WTP (Freeman, 2003).

Content validity depends on the extent to which an empirical measurement adequately reflects the structure of the market and the description of the amenity (Mitchell and Carson, 1989). Content validity is examined by assessing the survey instrument, the elicitation question, and the payment vehicle (Freeman, 2003). Freeman (2003) suggests that a WTP question is employed to achieve the most valid results. To establish content validity, Mitchell and Carson (1989) suggest that researchers should circulate draft questionnaires among colleagues for comments before using them in the field and to include the questionnaires with the articles when sending them out for review.

Mitchell and Carson (1989) discuss construct validity in two areas, convergent and theoretical validity. Convergent validity is concerned with the correspondence between a measure and other measures of the same theoretical construct. The validity of a measure is confirmed to the extent by which a correlation exists or the measures converge (Mitchell and Carson, 1989). This type of construct validity may be hard to measure. Instead, construct validity will focus on the theoretical aspect.

Mitchell and Carson (1989) define theoretical validity as an assessment of the degree by which the findings of a study are consistent with theoretical expectations. These authors claim that theoretical validity is most often measured by regressing WTP against a group of independent variables that are believed to be determinants of WTP. After an analysis is completed, the size and sign of the estimated coefficients are examined and judged to be consistent or inconsistent with economic theory. Freeman 
(2003) states that an example of construct validity is to ensure that WTP is an increasing function of income. In other words, as an individual's income increases, so should an individual's WTP. Because WTP is income constrained, income should have a positive effect on WTP. An additional check of validity can be done by comparing a respondent WTP with their annual income. This type of check was performed in a similar study by Stumborg, Baerenklau and Bishop (2001). Stumborg, Baerenklau and Bishop (2001) found that out of 170 responses, only one respondent reported a WTP in excess of $1 \%$ of their annual income.

In 1992, the National Oceanic and Atmospheric Administration (NOAA) convened with a panel of social scientists to assess the reliability of estimates obtained by $\mathrm{CV}$. From panel conclusions, recommendation guidelines were obtained regarding $\mathrm{CV}$ survey design, administration and data analysis (Carson et al., 1995). The NOAA panel concluded that if their recommendations are followed, CV studies convey useful information and state that the measurements obtained can be viewed as reliable enough to be a starting point of a judicial process of damage assessment (Arrow et al., 1993).

\subsection{Theoretical Framework for Contingent Valuation}

Descriptions of the theoretical framework for $\mathrm{CV}$ are described in numerous sources (Bjornstad and Kahn, 1996; Champ, Boyle and Brown, 2003; Mitchell and Carson, 1989). This framework is grounded in the idea that WTP dollar amounts can be derived from welfare measures. Because the CV questions in this study were phrased as 
WTP, as opposed to willingness-to-accept (WTA), the following theoretical framework will focus on WTP. ${ }^{6}$

Although traditional measures of consumer benefit use ordinary (Marshallian) demand curves, problems result, largely because these demand curves do not hold utility constant, but rather hold income constant (Mitchell and Carson, 1989). Mitchell and Carson (1989) discuss the theoretical framework for CV surveys in terms of Hicksian welfare measures. Hicksian welfare measures are used because policy interest usually lies in the potential benefits measured from the consumer's initial level of utility (Mitchell and Carson, 1989). These welfare measures include compensating and equivalence measures, as well as surplus and variation measures. Compensating measures assume that the agent is entitled to his/her current level of utility or status quo endowment of property rights while equivalence measures assume that the agent is entitled some alternative level of utility or set of property rights different from those currently held. Surplus measures constrain the quantity of the good being considered at the quantity which would be purchased at the new price in absence of compensation while variation measures do not constrain the quantity of the good the agent would purchase (Mitchell and Carson, 1989) . Mitchell and Carson (1989) assert that the measures obtained by CV can be represented in terms of the difference between two expenditure functions. According to modern consumer theory in Deaton and Muellbauer (1980) and Varian (1984), referenced in Mitchell and Carson (1989), the expenditure function is one of the four ways to represent a constrained utility maximization problem, which can be written as:

$$
\mathrm{e}(\mathrm{p}, \mathrm{q}, \mathrm{U})=\mathrm{Y},
$$

\footnotetext{
${ }^{6}$ Mitchell and Carson (1989) define WTA as the amount of money that would have to be given to an agent to forgo a change in a good and still be as well off as if the change had occurred. These authors assert that the WTA format should be avoided because it does not elicit valid data under many circumstances.
} 
where $p$ is a vector of prices, $q$ is a vector of fixed public goods, $U$ is a level of utility and $Y$ is the minimum amount of income needed to maintain utility level $U$ given the price and public goods vectors.

Mitchell and Carson (1989) state that letting $\mathrm{p}_{0}, \mathrm{q}_{0}, \mathrm{U}_{0}, \mathrm{Y}_{0}$ represent some initial level of those respective variables, and $\mathrm{p}_{1}, \mathrm{q}_{1}, \mathrm{U}_{1}, \mathrm{Y}_{1}$ represent some subsequent levels, changed by the improvement in water quality within Opequon watershed, we can represent compensating surplus $(\mathrm{CS})$ as:

$$
\begin{gathered}
\mathrm{CS}=\left[\mathrm{e}\left(\mathrm{p}_{0}, \mathrm{q}_{0}, \mathrm{U}_{0}\right)\right]-\left[\mathrm{e}\left(\mathrm{p}_{0}, \mathrm{q}_{1}, \mathrm{U}_{0}\right)\right] \\
\mathrm{CS}=\mathrm{Y}_{0}-\mathrm{Y}_{1} .
\end{gathered}
$$

If CS is positive, then $\mathrm{q}_{1}$ is preferred to $\mathrm{q}_{0}$ and the consumer would be willing-to-pay up to the point where their utility level was the same as it was in the initial situation. Mitchell and Carson (1989) follow this with an extension to the Hicksian equivalence welfare measure.

As one can see in equation (2-2), variables $p, q$ and $Y$ are the ones whose levels change and an individual's utility level remains constant at the initial level. Relating theory to this study, price refers to that being paid for the improvement in water quality, quantity refers to the quality of water and income is the individual's annual income. All of these variables change. However, the improvement in water quality is offset by the change in income so that ones utility remains constant. This is the underlying theory of a CV and an individual WTP. An individual WTP represents the amount of money he/she would be willing-to-forgo, given the public good improvement while remaining on the same utility curve. 


\subsection{Water Quality Contingent Valuation Studies}

Numerous studies have examined water quality issues using a variety of techniques including CV (Brox, Kumar and Stollery, 2003; Collins, Rosenberger and Fletcher, 2005; Eisen-Hecht and Kramer, 2002; Hurley, Otto, Holtkamp, 1999; Loomis et al., 2000; Stumborg, Baerenklau and Bishop, 2001; Whitehead, 2000) (Table 2.1). Typically these studies estimate a household WTP for an improvement in water quality and were chosen to provide a background this study.

Table 2.1- Summary of Previous Water Quality CV Studies.

\begin{tabular}{|c|c|c|c|c|}
\hline Study & $\begin{array}{l}\text { Water } \\
\text { body }\end{array}$ & $\begin{array}{l}\text { Survey } \\
\text { type }\end{array}$ & $\begin{array}{c}\text { Response } \\
\text { rate }(\%)\end{array}$ & $\begin{array}{c}\text { Annual } \\
\text { household WTP } \\
\operatorname{range}^{7}(\approx)\end{array}$ \\
\hline $\begin{array}{l}\text { Brox, Kumar and } \\
\text { Stollery, (2003) }\end{array}$ & Grand River & Mail & $\approx 70$ & $\$ 60-\$ 123$ \\
\hline $\begin{array}{l}\text { Collins, } \\
\text { Rosenberger and } \\
\text { Fletcher }(2005)\end{array}$ & Deckers Creek & $\begin{array}{c}\text { Mail, } \\
\text { Internet, } \\
\text { and } \\
\text { personal } \\
\text { interviews }\end{array}$ & 53 & $\$ 154-\$ 206$ \\
\hline $\begin{array}{l}\text { Eisen-Hecht and } \\
\text { Kramer (2002) }\end{array}$ & Catawba River & $\begin{array}{l}\text { Mail and } \\
\text { telephone }\end{array}$ & 47 & $\$ 156$ \\
\hline $\begin{array}{l}\text { Hurley, Otto and } \\
\text { Holtkamp, (1999) }\end{array}$ & $\begin{array}{c}\text { Two small } \\
\text { watersheds in } \\
\text { Southern Iowa }\end{array}$ & Mail & $\approx 33$ & $\$ 60-\$ 97$ \\
\hline $\begin{array}{l}\text { Loomis et al. } \\
(2000)\end{array}$ & South Platte River & $\begin{array}{l}\text { Mail and } \\
\text { personal } \\
\text { interviews }\end{array}$ & $\approx 26$ & $\$ 296$ \\
\hline $\begin{array}{l}\text { Stumborg, } \\
\text { Baerenklau and } \\
\text { Bishop, }(2001) \\
\end{array}$ & Lake Mendota & Mail & 44 & $\$ 65-\$ 99$ \\
\hline Whitehead (2000) & Pamlico Sound & Telephone & 71 & $\$ 155-406$ \\
\hline
\end{tabular}

A study conducted by Brox, Kumar and Stollery (2003) addressed water quality on the Grand River, located in Southern Ontario Canada, through the use of a mail CV

\footnotetext{
${ }^{7}$ Estimates reported in 2006 year dollars. Original WTP estimates were adjusted using Consumer Price Index.
} 
survey. These authors addressed improved water quality by estimating the benefits of improved residential drinking water. This study specifically deals with item non-response and a method by which one can obtain a more accurate estimation by imputing values for unanswered survey questions that are conditional on a respondent's decision to answer a WTP question.

The CV survey used by these authors was administered by mail in the fall of 1994. Approximately 3,000 households made up the sample. To improve survey design, pre-tests were administered to households before the main survey was sent out. Brox, Kumar and Stollery (2003) used three different questions to obtain the valuation that residents placed on improved water quality. Two of the questions were asked in the form of WTP for water quality improvements while the third question was in the form of willingness-to-accept (WTA) for its decline. Brox, Kumar, and Stollery (2003) used a "yes/no" question in the general WTP questions, followed by a payment card list of amounts. These authors employed the maximum-likelihood estimation technique to compute results.

Brox, Kumar, and Stollery (2003) found an average WTP/WTA between $\$ 4.56$ and $\$ 9.42$ per household, per month. These authors concluded that the major determinants of individuals WTP were household income, number of children, education, perception of existing water quality and identification with environmental issues. There results suggest that higher income, better educated, and environmentally conscious residents, who view the current water quality problem as being severe, possess a greater WTP to solve water contamination problems. 
A similar study using CV and estimating the benefits of improved water quality was conducted by Hurley, Otto and Holtkamp (1999). These authors investigated rural residents' perceptions of the risk to water quality from large confinement facilities in two small watersheds of Southern Iowa. Respondents were asked their WTP to delay nitrate contamination from these facilities through the use of a mail CV survey. The study area is predominately agricultural, which is heavily dependent on surface water for household consumption. Residents in both watersheds have been concerned with agricultural pollutants for an extended period of time.

To obtain CV information, Hurley, Otto and Holtkamp (1999) sent a survey to a random sample of 1,000 residents of Clarke and Adams Counties Iowa. The authors found that residents of both counties had a WTP to delay nitrate contamination in their water source. These authors estimated an annual median WTP of just over $\$ 50$ for a tenyear delay, just under $\$ 65$ per year for a 15 -year delay and just over $\$ 80$ per year for a 20 year delay. The authors found these values to be statistically significant from zero and increasing as expected but found them not to be different from each other. Male respondents were found to be less willing than female respondents to pay for a delay in nitrate contamination. Education level and income of a respondent were found to positively influence WTP to delay nitrate contamination. These authors also found that the likelihood of a respondent remaining in an area for another five years positively influenced the median WTP to delay nitrate contamination. Hurley, Otto and Holtkamp (1999) assert that the results obtained in this study are similar to those obtained using the hedonic pricing method. 
A study estimating improved water quality in Lake Mendota was conducted by Stumborg, Baerenklau and Bishop (2001), and used a split sample mail CV survey. This survey estimated the total WTP of a group of Wisconsin residents. The authors state that extensive research specific to the lake allowed for a thorough understanding of the relationship between pollutant loading and water quality response, thus making the lake an excellent candidate for a CV study. Lake Mendota's primary pollution problem is the result of excessive phosphorus loading tied directly to both urban development and agricultural activity.

The Lake Mendota watershed was selected in 1993 as a priority watershed, initiating the process of developing a non-point source pollution control plan for the drainage basin. Because Lake Mendota is a prominent resource within the watershed, a separate water quality goal was established for the lake itself. The goal of the priority watershed program is to adopt a fifty percent load reduction, which the Wisconsin Department of Natural Resources estimated at a total cost of $\$ 17.8$ million over the next 10 years. After the mail CV survey was completed and results obtained a cost-benefit analysis was completed.

The developed CV survey consisted of a modified referendum format and was mailed to 500 residents of Dane County. Stumborg, Baerenklau and Bishop (2001) found that the payment time horizon had a significant effect on WTP. These authors state a mean annual WTP for those in the 10-year sub sample of $\$ 57$ and those in the three year sub sample to be $\$ 87$. This is in accordance with intuition because the annual payment required to purchase a good decreases as the payment horizon increases. Only one respondent reported a WTP in excess of $1 \%$ of its annual income. 
Whitehead (2000) conducted a study concerning water quality issues surrounding the Pamlico Sound, located in eastern North Carolina. This study focused on environmental equity issues between white and non-white individuals. The Pamlico Sound has suffered some severe water problems in recent years (Whitehead, 2000). He also states that the study area of eastern North Carolina has a large population of nonwhite residents compared to the rest of North Carolina. Both of these facts make this an excellent area for this case study.

The telephone survey technique was used to obtain respondent information. The sample included 415 white residents and 180 non-white residents, with a pooled sample size of 595 individuals. A close-ended question was used to obtain WTP information. Whitehead (2000) found the average WTP for water quality improvement to be approximately $\$ 345$ for white respondents and $\$ 132$ for non-white respondents. These estimates were found to be statistically different. The author asserts that differences in the demand structures of the two groups are statistically significant but that the differences due to socioeconomic variables are not significantly different. Whitehead (2000) maintains that the results suggest that differences in tastes and preferences contribute to differing demands for environmental quality improvements. The author relates this to the fact that white respondents recreate more in the Pamlico Sound than non-white respondents and that whites were found to be significantly more concerned than nonwhite respondents.

A study conducted by Collins, Rosenberger and Fletcher (2005) focused on Deckers Creek and used a variety of methods including mail, Internet and personal interviews to acquire the necessary information. Deckers Creek is located in Monongalia 
and Preston counties of West Virginia and suffers from numerous environmental problems found in the Appalachian region such as trash, sewage and acid mine drainage. Approximately 400 responses were acquired using the stated methods from people of the general public as well as members of a local watershed organization. The goal of this study was to estimate improvements for three attributes, determined through focus group interviews. They were aquatic life, scenery, and swimming.

Collins, Rosenberger and Fletcher (2005) used random utility theory for the estimation of economic values using a choice modeling approach. The economic values for full restoration of all three characteristics previously listed were estimated using multi-characteristic, choice experiments with nested logit models. Collins, Rosenberger and Fletcher (2005) were able to conclude that welfare estimates for improvements from moderate to full restoration of all three attributes ranged from $\$ 12$ to $\$ 16$ per month, per household. These authors found that potential users of Deckers Creek had the largest consumer surplus while non-users had the lowest gain from restoration. Users of the creek and the general public were found to be from the same population.

Eisen-Hecht and Kramer (2002) used varied CV techniques to estimate the benefits of maintaining the current level of water quality in the Catawba River. The Catawba River is located in the mountains of western North Carolina and central South Carolina, and flows for 224 miles on a system of 11 reservoirs. Many of the surrounding municipalities receive their drinking water from the Catawba River and also return their wastewater to this river. In addition to this, the Catawba River is used heavily for recreational purposes and is also enjoyed for its aesthetic qualities. Population growth is 
also cited as one factor increasing the pressure on the Catawba River and its diversity of services provided.

Eisen-Hecht and Kramer (2002) state that economic benefits were estimated by mail and telephone techniques for a management plan to protect water quality in the Catawba basin. Focus group interviews and pre-tests were arranged and conducted to gather the necessary information to compile and finalize the survey. Eisen-Hecht and Kramer (2002) used the watershed analysis risk management framework (WARMF) model for improvement scenarios in the Catawba River. The WARMF model was used to estimate the amount of management activities needed to protect the current level of water quality in the basin over time. With the help of an independent business, these authors surveyed approximately 1,000 area residents. Eisen-Hecht and Kramer (2002) calculated an annual mean WTP of $\$ 139$.

Loomis et al. (2000) examined the total economic value of restoring ecosystem services in an impaired river basin. The impaired river basin that this study focused on was the South Platte River which is located near Denver, Colorado. The South Platte has been modified by diversions, adjacent land use, and pollution to the point where the river's ecosystem, including its aquatic life, is severely impaired (Loomis et al., 2000). To conduct their analysis, these authors used a variety of data collection techniques including in-person interviews and mail surveys. Before the survey was finalized and distributed, these authors worked with an interdisciplinary team to develop the instrument and other visual aids. Survey development included focus group interviews and pre-tests. Loomis et al. (2000) found that households on average were willing to pay $\$ 21$ per month or $\$ 252$ per year for additional ecosystem services. 


\subsection{Aggregating Household Willingness-to-Pay}

Throughout the literature, CV water quality studies describe the process by which total benefit estimates are achieved for the entire study area (watershed) population (Brox, Kumar and Stollery, 2003; Collins, Rosenberger and Fletcher, 2005; Eisen-Hecht and Kramer, 2002; Loomis et al., 2000; Stumborg, Baerenklau and Bishop, 2001). In addition to this, Mitchell and Carson (1989) discuss the aggregation of individual WTP values. Mitchell and Carson (1989) state that once the correct measure (WTP) for a sample of individuals has been obtained, aggregation of this value is done to obtain the total benefits for the good being valued (e.g. improved water quality). These authors reference Samuelson (1954) in his assertion that demand for public goods must be summed vertically to estimate total values as opposed to private goods which are summed horizontally to estimate total value.

Collins, Rosenberger and Fletcher (2005) aggregate WTP values by estimating different welfare measures depending on the sub-sample and assuming that nonrespondents had a zero WTP for restoration. These authors then multiplied a variety of estimated respondent welfare measures by the total number of households within the study area to achieve annual total benefit estimates. Collins, Rosenberger and Fletcher (2005) found a value for full restoration of three attributes related to Deckers Creek to be approximately \$1.9 million annually. Stumborg, Baerenklau and Bishop (2001) use mean household WTP estimates, their standard deviation, 1990 Census survey report data, and a 95\% standard normal confidence interval to determine a county-wide WTP for improved water quality of approximately $\$ 55$ million $\pm \$ 11$ million. 
Brox, Kumar and Stollery (2003) aggregate WTP values, by describing a process they used to place individual monthly WTP values in a wider context. These authors multiply a monthly WTP by the estimated number of households within the study area. Brox, Kumar and Stollery (2003) then discounted these values using a discount rate over an assumed time period for capital projects which translated to a capital value of $\$ 1,400$ per household. Brox, Kumar and Stollery (2003) state that this implies residents of the watershed are willing-to-fund a one-time investment of approximately $\$ 364$ million. Eisen-Hecht and Kramer (2002) approximate an aggregate present value of approximately $\$ 340$ million for all taxpayers in their study area (Catawba River Basin). These authors do so by also assuming a time span in which benefits would be received. In addition to this, these authors factor in a growing population. An annual value of approximately $\$ 75$ million was discounted using a determined discount rate, while assuming a zero rate of inflation.

To aggregate their WTP values, Loomis et al. (2000) create three scenarios to calculate the total economic value of restoring ecosystem services within the study area. A similar type of scenario analysis will be used to aggregate WTP values for Opequon watershed. Scenario one applies the estimated household monthly mean WTP value to all households of the study area. Scenario two is a more conservative estimate that applies the mean WTP to the percentage of households which agreed to participate in the survey. Scenario three is the most conservative scenario which applies the mean WTP to the percentage of households that actually responded to the survey. These authors calculate annual total benefit measures ranging from approximately $\$ 19$ to $\$ 71$ million. 


\subsection{Methodology}

An essential element of an environmental economics analysis is to compare all the benefits of a proposed action to all the costs. Such an analysis is seriously flawed without monetary values for the environmental goods affected by a proposed action (Carson, 2000). By balancing the costs of public goods against their benefits, decision makers can arrive at more informed choices. Although this study will not explicitly compare the costs of improved water quality with its benefits, the nature of the valuation is the same.

One economic valuation technique to elicit individual preferences and willingness-to-pay (WTP) for an improvement in a public good is contingent valuation (CV). The goal of any CV survey is to obtain an accurate estimate of the benefits of a change in the level of provision for some public good. To do this, the survey must meet the methodological imperatives of survey research and the requirements of economic theory (Mitchell and Carson, 1989). Portney (1994) claims that there is no standard approach to the design of a CV survey, but does assert that virtually all CV surveys consist of several well-defined elements.

\subsection{Survey Development}

For valuation of water quality improvements on the Opequon watershed, a CV survey instrument was designed and developed during the summer of 2005 . The water quality improvements were to approximate the expected outcomes from Total Maximum Daily Load (TMDL) implementation. TMDL implementation is the selected way to achieve water quality improvements within Opequon watershed. The survey instrument was designed using suggestions from Dillman’s (2000) Tailored Design Method. ${ }^{8}$ To

\footnotetext{
${ }^{8}$ Time and budget constraints prevented the use of Dillmans' methods for survey distribution.
} 
develop the survey instrument, meetings were held with the TMDL Steering Committee in Winchester, Virginia, and the Opequon Creek Project Team (OCPT) in Hedgesville, West Virginia. In addition to attending these meetings, two focus group interviews were administered. Krueger and Casey (2000) state that focus group interviews provide a way to gather information in order to better understand how people feel or think about an issue. These interviews were conducted in accordance with suggestions made by the above mentioned authors. In addition to this, surveys used in previous CV water quality studies were obtained. These surveys were acquired from a variety of sources including faculty members at West Virginia University (WVU) as well as professors at other universities around the United States.

The first focus group took place at the Timbrook Public Safety Building located in Winchester, Virginia on May $11^{\text {th }}, 2005$. Approximately eleven members who had attended the Opequon and Abrams Creeks TMDL Implementation Plan (IP) Steering Committee meeting participated. The second focus group took place at the James Rumsey Technical Institute located in Hedgesville, West Virginia on May $17^{\text {th }}, 2005$. This focus group took place with the OCPT. Approximately twelve members who attended this meeting participated. During these discussions, participants shared their experiences with the creeks, expressed their ratings of the current state of the creeks, described existing limitations for creek use, and portrayed possible changes in the creeks and their tributaries from water quality improvements. Additional topics discussed were the ways to cover TMDL implementation costs, as well as questions that should be included in the survey. These interviews helped provide valuable information from 
residents of the area concerning questions to include in the survey and ways to phrase the questions.

Field trips were also arranged to view Opequon and Abrams Creeks as well as their surrounding tributaries such as Red Bud Run and Tuscarora Creek. Viewing occurred at numerous locations, in both Virginia and West Virginia. Knowledgeable citizens living within the watershed area guided members of the WVU research team on tours of the watershed. Other watershed officials were interviewed, sharing information from which the survey instrument was drafted. All of these preparations helped gather the necessary information to begin drafting the survey.

After preliminary survey drafts had been written, internally discussed and revised, three pre-tests were conducted to determine watershed residents' opinions of the survey instrument. Pre-tests took place with the Kiwanis Club of Winchester, citizens attending the TMDL IP meeting held at Shenandoah University in Winchester, Virginia and again with the OPCT. These pre-tests took place on June $15^{\text {th }}, 2005$ and July $7^{\text {th }}, 2005$ and July $12^{\text {th }}, 2005$ respectively. A fourth pre-test was arranged and set-up at the Inwood, West Virginia Farmers Market but yielded few results, because of very few visitors shopping at the farmers' market that day. Approximately fifteen individuals participated in the pretest with the Kiwanis Club, twelve individuals attending the TMDL IP meeting and ten individuals attending the OCPT meeting. These pre-tests were informative because they field tested the developed instrument, allowing for minor modifications to be made. These modifications centered on slight changes in wording and descriptions. In addition to these changes, a question asking for the respondent to indicate their race was also omitted because of possible respondent objections. 
In addition to this, comments and suggestions about the instrument were obtained from numerous individuals. These individuals included people of the general public as well as people familiar with CV surveys. After this period, the survey instrument was finalized. It was submitted to the Internal Review Board for approval and prepared for printing. Cover letters were also finalized, which briefly described the study and invited the respondent to participate in the survey.

\subsection{Survey Design}

The final survey instrument included types of questions such as open-ended, checklist, scaled, and likert. Three similar survey instruments were designed for three separate sub-samples of households: (1) West Virginia general public (WVGP); (2) Virginia general public (VAGP); and (3) Virginia riparian landowner (VARL). ${ }^{9}$ Because pollution problems and causes, as well as recreational uses of the main creeks are different in both states, separate surveys were developed for Virginia and West Virginia general public residents.

The general format for each sub-sample was the same. Each survey instrument included questions about one's use and knowledge of Opequon watershed, one's opinion of local environmental quality and improvements to Opequon watershed, and one's socio-economic characteristics. In addition to these questions, the instrument included two CV questions concerning Opequon watershed clean-up projects, one for in-state improvements and one for out-of-state improvements. Working in conjunction with the individuals preparing the TMDL IP, preliminary analyses of various implementation actions have shown that many of them would impose additional costs on riparian landowners. However, it is also expected that riparian landowners would benefit most

\footnotetext{
${ }^{9}$ All three survey instruments can be found in Appendix 1.
} 
from improvements in water quality. Because of this, additional questions asked Virginia riparian landowners about their opinion of water quality problems and their willingnessto-implement various best management practices with or without government cost-share.

Water quality improvements were described in terms of improved sport (game) fish populations and the safety of swimming and wading. In the designed survey instrument, respondents were asked how much they were willing-to-pay for such water quality improvements. For in-state water quality improvements, the question was phrased using local taxes as the payment vehicle. For out-of-state water quality improvements, the question was phrased using a one-time donation to a hypothetical clean-up fund as the payment vehicle. Mitchell and Carson (1989) state that payment vehicles should have a connection to the improvement it is used to value and should also be neutral with respect to the environmental amenity. These authors assert that taxes are one vehicle most often used in CV studies.

A combined approach was used in terms of elicitation methods for this survey. In the first CV question, for in-state clean-up, respondents were asked in referendum format how they would vote (Support, Oppose, or Remain neutral/not participate) with respect to the described change in the watershed. The referendum format involves asking each respondent how they would vote if faced with an environmental improvement and having to pay for such improvement by using a method such as an increase in taxes (Carson et al., 1995). After this vote was cast, respondents were to answer one of the following two questions. The question they answered depended on their initial response.

If the respondent voted in Support of the described change, respondents were asked using the modified payment card technique, the maximum amount they were 
willing-to-pay for the described environmental improvement. The modified payment card technique varies slightly from the traditional payment card method. The traditional payment card method is most often used for in-person interviews and provides the respondent with a greater context for their bid. It does so by identifying some dollar amounts that the average household, in the same income bracket, is paying for other public goods (Mitchell and Carson, 1989). The modified payment card method is not subject to starting-point biases but the range of numbers may bias responses (Congressional Research Service, 1999).

This survey employed the modified payment card method because of mail survey distribution (opposed to the traditional payment approach). In addition, respondents were not given estimates regarding the prices they may pay for other public goods. Instead, a wide array of dollar amounts was provided and the respondent was simply asked to circle the maximum dollar amount they were willing-to-pay for the described improvements. If the respondent voted to Oppose or Remain neutral/not participate, they were asked to check which statement most accurately described the reason for not to supporting the change. ${ }^{10}$ This question included three protest responses to the original $\mathrm{CV}$ question. If none of the statements reflected their reasoning, respondents could write in their own reason for opposing this project.

In the second CV question, for out-of-state clean-up, respondents were asked how much they would be willing to donate in a one-time payment to a hypothetical Opequon Creek watershed restoration fund. This type of elicitation method was used because local taxes cannot cross state boarders, therefore making taxes an unrealistic payment vehicle

\footnotetext{
${ }^{10}$ This question directly followed the CV question and is question 10,11 and 14 in the West Virginia, Virginia and riparian landowner surveys respectively (Appendix 2).
} 
for respondents. The payment vehicle varied depending on the CV question (in-state vs. out-of-state) to provide the most realistic situation in which payments could be collected.

The following is the survey question describing the water quality problems within the West Virginia portion of Opequon watershed and the clean-up plan presented to respondents (Figure 3.1). Because the change in the watershed is a proposed change, rather than one that has already occurred, the valuation process proceeds from an ex ante perspective (Bergstrom, Boyle and Poe, 2001). Mitchell and Carson (1989) assert for most welfare economic purposes, the ex ante perspective is considered most appropriate when uncertainty of outcomes is involved.

Opequon Creek is currently polluted with excessive nutrients and bacteria from sources such as agriculture, urban runoff, and sewage occurring in West Virginia. Because of these pollutants, no swimming or wading is recommended in Opequon Creek. While this creek is stocked annually with trout, not all portions of the creek can support year-round sport fish populations (bass, bluegill, trout, etc.). Assume that you are asked to vote on a project that would provide the funding required to clean up Opequon Creek. In about five years, this clean up would make Opequon Creek safe for swimming and wading. It would also provide habitat for year-round fish populations. This project would raise county taxes over a five-year period in order to pay for the clean up project. Would you support, oppose, or remain neutral about this project?

Figure 3.1- West Virginia CV Question.

The following is the survey question describing the water quality problems within the Virginia portion of Opequon watershed and the clean-up plan presented to respondents (Figure 3.2). Virginia riparian landowners were presented the same information and water quality improvement plan as households receiving the VAGP survey. 
Opequon and Abrams Creeks are currently polluted with dirt and sediment along with sewage and bacteria. Because of these pollutants, no swimming or wading is recommended in the Virginia portion of these Creeks. Assume that you are asked to vote on a project that would provide the funding required to clean up Opequon and Abrams Creeks. In approximately five years, this clean up would make Opequon and Abrams Creeks safe for swimming and wading in the Virginia portion. This project would raise local taxes over a five-year period in order to pay for the clean up project. Would you support, oppose, or remain neutral about this project?

Figure 3.2- Virginia CV Question.

Two of the primary recommendations from National Oceanic and Atmospheric Administration (NOAA) conclusions were followed in the development of this survey. This included employing a referendum approach as well as including an, "I would not vote" response (in the instrument phrased as Remain neutral/not participate). General recommendations of the NOAA panel were also followed such as using a conservative design, using a WTP elicitation format, including detailed information on the resource in question and including a scientific evaluation of its ecological importance and a description of possible outcomes from protective measures (Arrow et al, 1993; Carson et al., 1995).

\subsection{Survey Distribution}

A total of 5,000 surveys were distributed by mail to a random sample of households within the watershed. Of these, 2,500 surveys were mailed to general public households in West Virginia, 2,300 to general public households in Virginia and 200 to Virginia riparian landowners. Each mailing contained a cover letter explaining the study, a survey instrument and a return envelope. Addresses of approximately 400 Virginia Opequon and Abrams Creek riparian landowners were obtained from an individual associated with the clean-up of these creeks. ${ }^{11}$ It was decided that 200 surveys would be

\footnotetext{
${ }^{11}$ West Virginia riparian landowners along Opequon Creek were not surveyed because of lack of information regarding their name and address.
} 
randomly sent to these Virginia landowners, which represent the third sub-sample of respondents.

A random sample of the watershed population was obtained from Custom Pack $\mathrm{N}$ Ship (CPNS) of Morgantown, West Virginia (Table 3.1). Because the names and addresses of the households within the sample are confidential, CPNS addressed the cover letters appropriately and administered the mailing of all 4,800 surveys to the general public. Initially, sampling strategies were discussed that included sampling by circles, with a radius around a center location. However, this particular sampling strategy was determined to be too expensive. While watershed boundaries cross state and county boundaries, most population data are managed according to administrative borders. Because of this, the smallest administrative unit from which the household addresses could be obtained was by zip code.

Table 3.1- Summary of the Sample by Sub-sample.

\begin{tabular}{|l|c|c|}
\hline Sub-sample & $\begin{array}{c}\text { Total number of } \\
\text { households within each } \\
\text { sub-sample }\end{array}$ & $\begin{array}{c}\text { Total number of } \\
\text { households sampled }\end{array}$ \\
\hline Virginia general public & 19,330 & 2,300 \\
\hline West Virginia general public & 24,569 & 2,500 \\
\hline Virginia riparian landowner & $392^{13}$ & 200 \\
\hline Total & 44,291 & 5,000 \\
\hline
\end{tabular}

Zip codes were selected when at least half of their area was within the watershed.

In other words, the center of the zip code lay within the watershed. Within each zip code, the proportion of surveys distributed was equal to the same proportion of households within the respective portion of the watershed. There were ten zip codes that fit this criterion. However due to budget limitations, only a total of eight zip codes were used in

\footnotetext{
${ }^{12}$ Total household estimates are important because they will later be used to aggregate WTP to the population (Section 4.5).

${ }^{13}$ To include VARL household estimates, 392 households were deleted from the Virginia general public state total.
} 
the sample. This included four zip codes from Virginia and four zip codes from West Virginia. Of the eight zip codes chosen, five of the zip codes lay completely within the watershed. Because only four zip codes were selected in Virginia, two zip codes in West Virginia, 25420 and 25446, which met the above criteria, were deleted. This was done so that each state had the same number of zip codes selected for the sample. If one were to look at a map of the watershed detailing zip code areas (Figure 3.3), it appears that zip code 22602 has a large portion outside of the watershed. However, if this zip code was omitted from the sample, possible respondents living near the Upper portion of Opequon Creek would not have been sampled. This zip code also met the above criterion of having at least half of its area within the watershed. Zip codes were sampled based on Census household estimates as well as Census block estimates using ArcView Software. A possibility existed that a household outside of the watershed in each sampled zip code could obtain a survey. However, this error was minimized by using ArcView. 


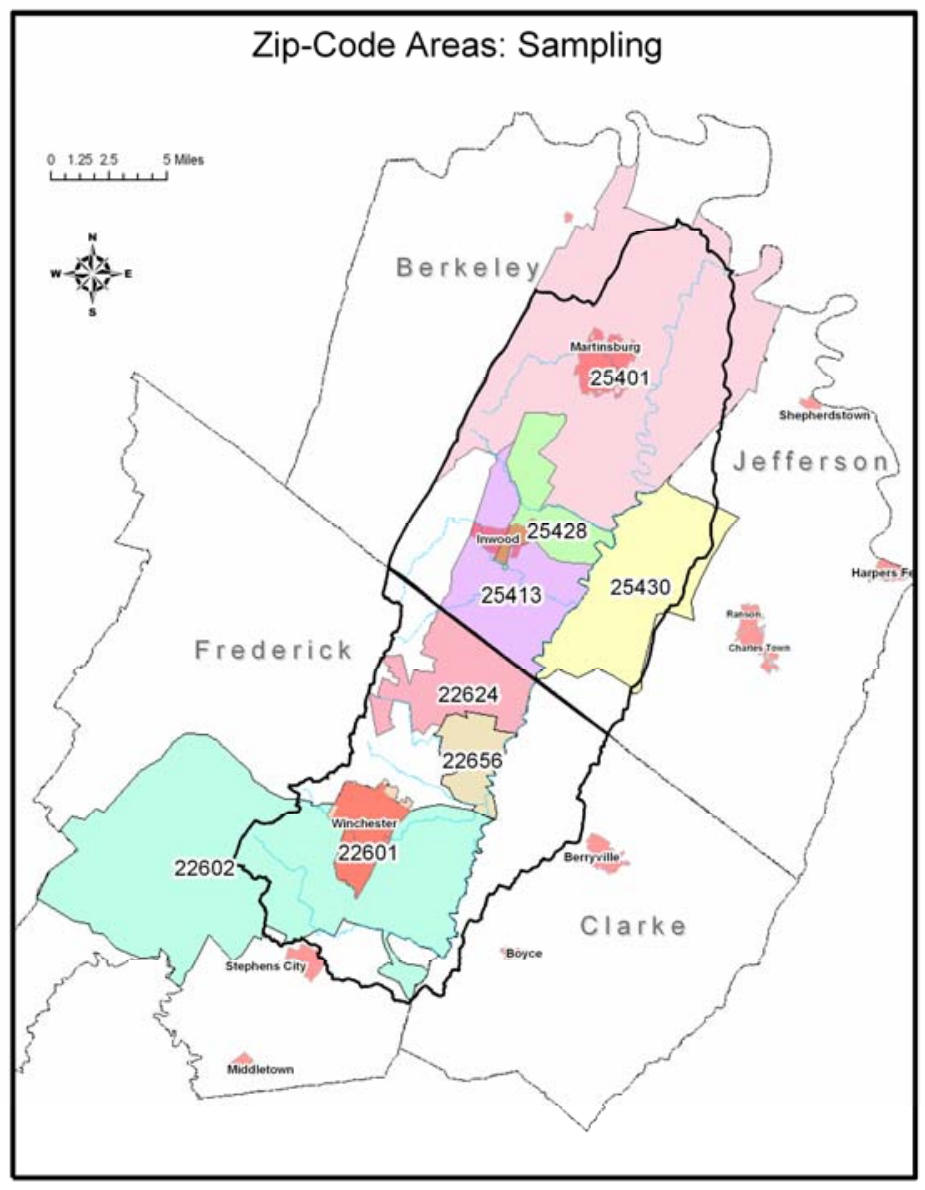

Figure 3.3- Map of the Sampled Zip Codes. *Produced by Dr. Tatiana Borisova Although recommendations from Dillman (2000) were used to design and develop the survey instrument, this author's recommendations were not used for the sampling procedure. Dillman (2000) describes the traditional sampling procedure, which uses a smaller sample with multiple rounds of mailing to solicit responses. However, because of time and budget constraints, an alternative strategy was adopted which used a larger sample, with only one round of mailings to the general public with a follow-up reminder postcard. 
Because of only one mailing, as well as other distribution practices, their may be a potential for low response rates. Limited financial resources prevented me from completing various mail survey distribution practices. These practices include advanced warning of the survey request or an incentive (reward) to complete the questionnaire. However, less costly practices were adopted in hopes of attracting more respondent's. The logo of a university affiliated with this study was included on the cover of all questionnaires sent to Virginia residents, and the watershed organization associated the TMDL IP was included as a singer in the cover letter. Including the name of this university and organization was done to show Virginia residents that local Virginia entities were associated with the survey. Lastly, the potential for survey non-response error will be mitigated through statistical techniques and using different methods of analysis.

To increase survey response rates, a reminder postcard was designed and mailed to all households that received the survey instrument (Appendix 2). This includes households of the 4,800 general public random sample as well as the 200 sampled Virginia riparian landowner households. A second survey was not mailed to general public households but was distributed to the sampled Virginia riparian landowners. In addition to this, two local newspapers within the watershed were contacted and asked to write an article detailing the survey. The Winchester Star, published in Winchester, Virginia and The Journal, published in Martinsburg, West Virginia both published articles about the study to coincide with survey distribution.

Table 3.2 summarizes the dates which materials were mailed to all three subsamples. Virginia riparian landowner surveys were mailed to potential respondents first, 
approximately the middle of August. After this, general public surveys were mailed the first week of September by CPNS. Reminder postcards were mailed near the end of September and beginning of October. A second set of surveys to all Virginia riparian landowner households was mailed during the second week of September, allowing for an eight week interval between survey mailings.

Table 3.2- Summary of the Dates which Materials were mailed.

\begin{tabular}{|l|c|c|c|}
\hline Survey & $\begin{array}{c}\text { Date of first survey } \\
\text { distribution }\end{array}$ & $\begin{array}{c}\text { Date of reminder } \\
\text { postcard distribution }\end{array}$ & $\begin{array}{c}\text { Date of second } \\
\text { survey distribution }\end{array}$ \\
\hline $\begin{array}{l}\text { Virginia riparian } \\
\text { landowner }\end{array}$ & August $19^{\text {th }}, 2005$ & September $24^{\text {th }}, 2005$ & October $10^{\text {th }}, 2005$ \\
\hline $\begin{array}{l}\text { Virginia general } \\
\text { public }\end{array}$ & September $2^{\text {nd }}, 2005$ & October $4^{\text {th }}, 2005$ & - \\
\hline $\begin{array}{l}\text { West Virginia } \\
\text { general public }\end{array}$ & September $9^{\text {th }}, 2005$ & October $11^{\text {th }}, 2005$ & - \\
\hline
\end{tabular}

\subsection{Empirical Model Specification}

For each sub-sample, different empirical WTP models were developed with the assumption that an individual WTP is a function of a set of explanatory variables. A generic WTP model for each sub-sample can be represented as:

$$
W T P_{\mathrm{i}}=W T P_{\mathrm{i}}\left(K_{\mathrm{i}}, X_{\mathrm{i}}, S_{\mathrm{i}}\right)
$$

where $W T P_{i}$ is individual i's maximum WTP for improved water quality within a designated portion of the watershed; $K_{i}$ represents variables concerning individual i's use and knowledge of the creek; $X_{i}$ represents variables concerning individual i's attitudes and opinions of local environmental quality including aquatic ecosystems; and $S_{i}$ represents socio-economic characteristics for individual i.

The empirical model employed to analyze the survey data is a grouped tobit model, which is grounded in the formulation by Greene (2002). The tobit model is an extension of the probit model and was developed by Tobin (1958). Tobit models refer to 
regression models where the dependent variable is constrained in some way (Amemiya, 1984). In other words, the tobit model is a censored regression model. ${ }^{14}$ Kennedy (2003) defines a censored sample as one when observations on the dependent variable, corresponding to known values of independent variables, are not observable. The tobit model is referred to as a limited dependent variable model because of the restrictions put on the values taken by the regressand (Gujarati, 2003). A common feature of WTP data is that observations on the dependent variable, which lie within a certain range, are reported as a single value. Because of this, tobit models are employed when observations which are less than zero, can be translated to (reported as) zero values (Kennedy, 2003).

A grouped tobit model is based on a censoring of the dependent variable, WTP. The grouped tobit model censors the dependent variable into categorical data (Greene, 2002). The grouped tobit model differs from the ordered probit in that the threshold values are known (Greene, 2002). As described by Rosenberger, Collins and Svetlik (2005), a payment card elicitation technique results in value responses based on intervals or groups. While the thresholds separating the intervals are known, the exact WTP value for each respondent is not observed, resulting in ordinary least squares estimators providing biased estimates (Cameron and Huppert, 1989). Because a respondent's maximum WTP was elicited using a modified payment card approach, a grouped model is best where an efficient maximum likelihood estimator can be used to fit a bid function to the valuation data.

Respondents were divided into two groups, one consisting of supporters of the improvement plan, and another consisting of those individuals who opposed or would

\footnotetext{
${ }^{14}$ Censored regression models should be distinguished from truncated models which refer to the use of models when values on independent variables are known, only when the dependent variable is observed (Wooldridge, 2006).
} 
remain neutral regarding the clean-up plan. It was assumed that supporters of the cleanup plan had a positive WTP for water quality improvements, while individuals who oppose or remain neutral about the plan had a zero WTP for water quality improvements. Only those individuals who had a positive WTP for water quality improvements, were included in the model. Kennedy (2003) asserts that this type of sample selection should be met with caution when generalizing to the larger population as well as because some researchers arbitrarily determine which observations should be included in the model. However, sample selection bias should not be an area of concern for this analysis. Sample selection bias was negated by including non-protest zero WTP respondents when estimating household and aggregate WTP values. Symbolically, each observation on WTP is bounded between observed lower and upper limits from the modified payment card: ${ }^{15}$

$$
\begin{gathered}
\mathrm{WTP}=1 \text { if } \mathrm{WTP}^{*}<5, \\
2 \text { if } 5 \leq \mathrm{WTP}^{*}<10, \\
3 \text { if } 10 \leq \mathrm{WTP}^{*}<15, \\
\vdots \\
\mathrm{J} \text { if } \mathrm{WTP}^{*} \geq 1,000 .
\end{gathered}
$$

Formally, the grouped data tobit model is represented in Greene (2002), when the dependent variable is not observed, as:

(3-3) (Unobserved) $\quad \mathrm{WTP}^{*}=\beta^{\prime} \mathrm{X}+\varepsilon$ where $\varepsilon \sim \mathrm{N}\left(0, \sigma^{2}\right)$.

When the dependent variable is observed, the model is represented by Greene (2002) as:

(3-4) (Observed) $\quad \mathrm{WTP}=\mathrm{j}$ if $\mathrm{A}_{\mathrm{j}-1} \leq \mathrm{WTP}^{*}<\mathrm{A}_{\mathrm{j}}$ where $\mathrm{j}=1$ to $\mathrm{J}, \mathrm{A}_{0}=-\infty$, and $\mathrm{A}_{\mathrm{J}}=+\infty$.

\footnotetext{
15 The values on the modified payment card can be found in question 9(b), 10(b) and 13(b) in the West Virginia, Virginia and riparian landowner surveys respectively (Appendix 1).
} 
However, because one's exact (true) WTP was not reported, equation (3-3) will be used for this study.

Because the threshold values are known, an estimate of the scale parameter $(\sigma)$ of $W T P^{*}$ is also provided. Let $L_{i}$ and $U_{i}$ denote the lower and upper limits respectively, of the payment card interval in which $W T P_{i}$ is observed. When $W T P_{i}$ is equal to 1 , then $L_{i}$ is - $\infty$ and $U_{i}$ is $A_{1}$. The conditional mean function is the expected value of $W T P^{*}$ in this range. The log likelihood function to maximize becomes:

$$
\log \mathrm{L}=\sum_{i=1}^{n} \log \left[\Phi\left(\mathrm{Z}_{\mathrm{Ui}}\right)-\Phi\left(\mathrm{Z}_{\mathrm{Li}}\right)\right]
$$

where $\Phi(\cdot)$ is the cumulative standard normal density function, $Z_{\mathrm{ji}}=\left(\mathrm{j}-\beta^{\prime} \mathrm{X}\right)$, and $\mathrm{j}=$ lower $(\mathrm{L})$ or upper $(\mathrm{U})$ interval limits for respondents $(\mathrm{i}=1$ to $n)$.

Table 3.3 describes the independent variables created from the survey instrument and included in the analysis. These variables were chosen because of similar previous CV studies as well as economic theory. In addition, these variables were chosen because of their importance with respect to this study. All variables except QUALITY and DISTRUST are expected to have a positive relationship with a respondent WTP. Uncertainty surrounds the sign on variables GENDER, LIFE and LAND. There is uncertainty with these variables because of several different arguments that could be made describing their relationship with WTP as well as the findings in previous literature.

In previous studies, variables representing one's use or knowledge of the environmental problem were found that had a positive relationship with their WTP for the environmental improvement (Collins, Rosenberger and Fletcher, 2005; Rosenberger, Collins and Svetlik, 2005). One could also expect that as your use and knowledge of a creek increases, so would your WTP to improve it. In addition, previous studies found 
that variables representing one's opinion of their environment had a negative relationship with their WTP for an environmental improvement (Eisen-Hect and Kramer, 2002; Rosenberger, Collins and Svetlik, 2005). One could also expect that as your opinion of the environment decreases, your WTP to clean it up increases.

Dependent on the question, socio-economic variables were thought to have a varying relationship with regard to a respondent WTP for this environmental improvement project. From previous studies, income, age and years of education are all thought to have a positive effect on a respondent WTP (Brox, Kumar and Stollery, 2003; Collins, Rosenberger and Fletcher, 2005; Stumborg, Baerenklau and Bishop, 2001; Whitehead, 2000). Uncertainty surrounds the sign on variables representing a respondent's gender, time spent within the watershed and status of being a landowner. Hurly, Otto and Holtkamp (1999) and Stumborg, Baerenklau and Bishop (2001) found that being a male negatively influenced one's WTP. However, Collins, Rosenberger and Fletcher (2005) found that being a male positively influenced a respondent's WTP for a watershed improvement project. Hurly, Otto and Holtkamp (1999) also found that owning a home negatively influenced one's WTP for an environmental improvement plan. Because different arguments can be made for these variables, their signs are uncertain. 
Table 3.3- Summary of Variable Names, Description and Coding.

\begin{tabular}{|c|c|c|}
\hline $\begin{array}{l}\text { Variable } \\
\text { name }\end{array}$ & Variable description & $\begin{array}{l}\text { Expected } \\
\text { sign }\end{array}$ \\
\hline$W T P W V$ & $\begin{array}{l}\text { Grouped category of maximum willingness-to-pay for } \\
\text { water quality improvements in West Virginia. }\end{array}$ & $(+)$ \\
\hline WTPVA & $\begin{array}{l}\text { Grouped category of maximum willingness-to-pay for } \\
\text { water quality improvements in Virginia. }\end{array}$ & $(+)$ \\
\hline FAMILUP & $\begin{array}{l}\text { 1= Familiar with the Upper portion of Opequon Creek, } 0 \\
\text { otherwise. }\end{array}$ & $(+)$ \\
\hline FAMILWV & $\begin{array}{l}\text { 1= Familiar with the West Virginia portion of Opequon } \\
\text { Creek, } 0 \text { otherwise. }\end{array}$ & $(+)$ \\
\hline FAMIL & $\begin{array}{l}1=\text { Familiar with the opposite portion of Opequon } \\
\text { watershed, } 0 \text { otherwise. }\end{array}$ & $(+)$ \\
\hline USE & $1=$ Use creeks for recreation, 0 otherwise. & $(+)$ \\
\hline GENPROB & $\begin{array}{l}1=\text { Acknowledged general environmental problems in } \\
\text { creeks, } 0 \text { otherwise. }\end{array}$ & $(+)$ \\
\hline SEWAGE & $1=$ Aware of sewage problems in creeks, 0 otherwise. & $(+)$ \\
\hline DIRTSED & $1=$ Aware of dirt/sediment problems in creeks, 0 otherwise. & $(+)$ \\
\hline QUALITY & $\begin{array}{l}1=\text { Quality of environment in past few years has improved, } \\
0 \text { otherwise. }\end{array}$ & $(-)$ \\
\hline CONCERN & $\begin{array}{l}1=\text { Very concerned about fish and other aquatic life, } 0 \\
\text { otherwise. }\end{array}$ & $(+)$ \\
\hline TMDL & $1=$ Aware of TMDL, 0 otherwise. & $(+)$ \\
\hline TMDLEDU & $\begin{array}{l}\text { Interaction variable, TMDL*EDU. } 1=\text { aware of TMDL and } \\
\text { college or graduate school educated, } 0 \text { otherwise. }\end{array}$ & $(+)$ \\
\hline SWIM & $1=$ Regularly swim in a lake, creek, or river, 0 otherwise. & $(+)$ \\
\hline FISH & 1= Regularly fish in a lake, creek, or river, 0 otherwise. & $(+)$ \\
\hline VOTE & $\begin{array}{l}1=\text { Voted in support for the in-state clean-up plan, } 0 \\
\text { otherwise. }\end{array}$ & $(+)$ \\
\hline FISHSTOC & $\begin{array}{l}1=\text { Would like fish stocking as an improvement, } 0 \\
\text { otherwise. }\end{array}$ & $(+)$ \\
\hline PUBACC & $\begin{array}{l}1=\text { Would like public access for fishing and recreation as } \\
\text { an improvement, } 0 \text { otherwise. }\end{array}$ & $(+)$ \\
\hline DISTRUST & $\begin{array}{l}\text { 1= Distrust local government to make decisions about the } \\
\text { clean-up of watershed creeks, } 0 \text { otherwise. }\end{array}$ & $(-)$ \\
\hline GENDER & $1=$ Female, 0 otherwise. & (?) \\
\hline AGE & A respondents age (years). & $(+)$ \\
\hline$E D U$ & $\begin{array}{l}\text { 1= Education level with at least a college degree, } 0 \\
\text { otherwise. }\end{array}$ & $(+)$ \\
\hline
\end{tabular}




\begin{tabular}{|l|l|c|}
\hline $\begin{array}{l}\text { Variable } \\
\text { name }\end{array}$ & \multicolumn{1}{|c|}{ Variable description } & $\begin{array}{c}\text { Expected } \\
\text { sign }\end{array}$ \\
\hline LAND & $1=$ Home or residential landowner, 0 otherwise. & $(?)$ \\
\hline RIPLAND & $1=$ Riparian landowner, 0 otherwise. & $(+)$ \\
\hline LIFE & 1= Lived within the watershed their entire life, 0 otherwise. & $(?)$ \\
\hline INCOME & $\begin{array}{l}\text { Mid-point of survey categories. Under \$10k category= } \\
\$ 10 \mathrm{k}, \$ 200 \mathrm{~K}+=\$ 250 \mathrm{k}(\$ 1,000 \text { 's). }\end{array}$ & $(+)$ \\
\hline
\end{tabular}

\subsection{Methods of Analysis}

Initial econometric models were developed using ordinary least squares and logit. ${ }^{16}$ Final household WTP values for in-state and out-of-state water quality improvements were estimated using a grouped tobit econometric model. The software package LIMDEP was employed for this estimation process (Greene, 2002). Because the modified payment card approach was employed in the CV question, a grouped tobit model was needed to estimate a household WTP. Because a lognormal conditional distribution for WTP was used, the individual fitted conditional means and medians of WTP are easily reconstructed from the data (Cameron and Huppert, 1989). The individual fitted median $\mathrm{WTP}_{\mathrm{i}}$ for individual $\mathrm{i}$ is $\exp \left(\beta \mathrm{X}_{\mathrm{i}}\right)$. The individual fitted mean WTP values are calculated by scaling the mean by the estimated constant equal to $\exp \left(\sigma^{2} / 2\right)$, or conditional mean $\mathrm{WTP}_{\mathrm{i}}=\exp \left(\beta \mathrm{X}_{\mathrm{i}}+\sigma^{2} / 2\right)$. Thus, the conditional mean is sensitive to $\sigma$ values, where median estimates do not take $\sigma$ values into account. Individual mean and median annual WTP values were averaged over all respondents, including those respondents reporting a non-protest zero WTP. This was done to provide weighted estimates of the conditional average annual mean and conditional average annual median (Rosenberger, Collins and Svetlik, 2005).

\footnotetext{
${ }^{16}$ Preliminary models were estimated but were never seriously considered. These models were developed mostly as a learning tool.
} 
In $\mathrm{CV}$ surveys, there is often a proportion of the sample that is not willing-to-pay to obtain (avoid) an increase (decrease) in an attribute of a particular environmental public good. These responses are known as protest zeros (Lindsey, 1994). Protest beliefs are representative of attitudes towards the valuation process (Jorgensen and Syme, 2000). Jorgensen and Syme (2000) state that protest responses may stem from insufficient information, dissension towards the payment vehicle or pollution abatement intervention, ethical objections, or belief that it is the government's responsibility to fix environmental problems rather than the individual.

To identify protest zeros, respondents were asked to explain their zero WTP bids. Respondents did so by answering a follow-up question to determine if their responses were zero WTP values or protest responses to the survey or survey context (Collins, Rosenberger and Svetlik, 2005). To analyze protest responses, the number of respondents who stated a zero WTP value for each sub-sample was calculated. These respondents did so for a variety of reasons which included opposing the clean-up plan, remaining neutral about the plan or supporting the plan. These respondents were excluded from the grouped tobit model because it examined only those respondents with a positive WTP.

After splitting the sub-samples between supporters and non-supporters, the number of respondents who were protesting against at least one aspect of the CV question was determined. Because these respondents are protesting against the $\mathrm{CV}$ question, they can not be included when calculating WTP. For this study, protest responses included those who think that someone else should pay for water quality improvements, taxes were not the best way to pay for these improvements, or the improvements could not be accomplished. 
Comparisons of model coefficients were done using a log likelihood ratio (LLR) test (Gujarati, 2003). The LLR test statistic used was $2 *\left(L_{L} R_{U}-L_{L R}\right)$ using a $\chi^{2}$ distribution with degrees of freedom equal to the number of restrictions imposed by the null hypothesis. $\operatorname{LLR}_{\mathrm{U}}$ is the log likelihood ratio for the unrestricted model, which was computed from the sum of the individual LLRs from each sub-sample model. $L L R_{R}$ is the $\log$ likelihood ratio for the restricted model based on combining the two sub-samples into one pooled sample. For in-state WTP, two separate log likelihood tests were conducted comparing the WVGP and VAGP sub-samples and comparing the VAGP and VARL sub-samples. These LLR tests were conducted using WTP for in-state water quality improvements as the dependent variable in grouped tobit models.

When comparing WTP for in-state improvements by WVGP and VAGP subsamples, the null and alternative hypotheses for the estimated coefficients were:

$$
\begin{aligned}
& \mathrm{H}_{0}: \beta_{\mathrm{WVGP}}=\beta_{\mathrm{VAGP}}(\text { restricted model }) \\
& \mathrm{H}_{1}: \beta_{\mathrm{WVGP}} \neq \beta_{\mathrm{VGP}}(\text { unrestricted model }) .
\end{aligned}
$$

When comparing WTP for in-state improvements by VAGP and VARL subsamples, the null and alternative hypotheses for the estimated coefficients were:

$$
\begin{aligned}
& \mathrm{H}_{0}: \beta_{\mathrm{VAGP}}=\beta_{\mathrm{VARL}}(\text { restricted model }) \\
& \mathrm{H}_{1}: \beta_{\mathrm{VAGP}} \neq \beta_{\mathrm{VARL}}(\text { unrestricted model }) .
\end{aligned}
$$

A third comparison of model coefficients was done using a LLR test. This was completed using WTP for out-of-state improvements and was conducted comparing the WVGP and VAGP sub-samples. In this LLR test, WTP for out-of-state water quality improvements was the dependent variable in grouped tobit models. When comparing 
WTP for out-of-state improvements by WVGP and VAGP sub-samples, the null and alternative hypotheses for the estimated coefficients were:

$$
\begin{aligned}
& \mathrm{H}_{\mathrm{o}}: \beta_{\mathrm{WVGP}}=\beta_{\mathrm{VAGP}}(\text { restricted model }) \\
& \mathrm{H}_{1}: \beta_{\mathrm{WVGP}} \neq \beta_{\mathrm{VGP}}(\text { unrestricted model }) .
\end{aligned}
$$

While conducting all three LLR tests, each of the models contained identical variables from similar questions in each survey. Each model also contained the identical number of variables.

A range of discount rates were determined for a sensitivity analysis of in-state WTP results. Discount rates were needed to bring future clean-up payments to present day dollar value. After a thorough review of literature concerning possible discount rates for this study, it was clear that there was not one correct discount rate (Frederick, Loewenstein and O’Donoghue, 2002; Gately, 1980; Hausman, 1979; Metcalf and Hassett, 1999; Train, 1985). In the survey instrument, respondents were asked to pay for improved water quality within their state over a five-year time span. The literature which seemed most related to this type of decision was consumer energy related decision making literature. While conducting a literature review concerning discount rates, discount rates were found for numerous types of decision including wage-risk decisions, auto-safety decisions, consumer energy related decisions and financial payment decisions (lump sum vs. annuity).

Two literature reviews, Train (1985) and Frederick, Loewenstein and O’Donoghue (2002) detail discount rates for consumer energy related decision making. In these studies, consumers were asked how much money they needed to save per month in energy bills, to pay an extra specified sum up front for the respective good. This 
question poses a similar trade off as in the $\mathrm{CV}$ question. In the $\mathrm{CV}$ question, respondents were asked how much they were willing-to-spend per year, over five years to improve water quality within their state's portion of Opequon and/or Creeks. The basis for two of the discount rates used comes from the type of decision making process detailed in Train (1985). A third discount rate, a market interest rate, was chosen to provide a thorough analysis of discounting future payments. A market interest rate is appropriate because it allows for estimates to be put in the context of the cost of capital. Studies such as Brox, Kumar and Stollery (2003) and Eisen-Hecht and Kramer (2002) use this type of discount rate to aggregate yearly benefits over time.

To determine the first of three discount rates, the mid-point was calculated from discount rates summarized in Train (1985) (Table 3.4). After this was done, these midpoints were averaged to determine one discount rate. Train (1985) states discount rates for energy related appliances such as air conditioners and refrigerators, as well as other appliances, unspecified actions, space heaters and automobiles.

Table 3.4- Summary of Discount Rates obtained through Energy related decision making.

\begin{tabular}{|l|c|}
\hline Type of energy related decision & Discount rate range \\
\hline Thermal integrity & $10 \%-32 \%$ \\
\hline Space heating and fuel type & $4.4 \%-36 \%$ \\
\hline Air conditioning & $3.2 \%-29 \%$ \\
\hline Refrigerators & $39 \%-100 \%$ \\
\hline Other appliances & $18 \%-67 \%$ \\
\hline Automobiles & $2 \%-41 \%$ \\
\hline Unspecified actions & $3.7 \%-22.5 \%$ \\
\hline
\end{tabular}

When averaging the mid-point of studies referenced in Train (1985), a discount rate of approximately $29 \%$ is obtained. The second discount rate was also calculated by using studies referenced in Train (1985). Instead of averaging the mid-point of these studies, the low discount rate from these studies was averaged. When averaging the low 
discount of the some studies referenced in Train (1985) (Table 3.4), a discount rate of approximately $11 \%$ was calculated. For the third discount rate, a five-year Treasury bill interest rate of $4.25 \%$ was used. This is a five-year market rate of interest and was found on February 16 ${ }^{\text {th }}, 2006$ (Bloomberg.com).

To statistically control for the potential for non-response error, respondents were assumed to have a different WTP than non-respondents. Using the grouped tobit model, respondent and non-respondent WTP was modeled separately. Using these three discount rates, in-state median WTP calculations were done for both respondent and nonrespondent WTP estimates. Median WTP calculations included positive and non-protest zero WTP responses. Discounting took place for years one through four. WTP values for in-state clean-up were discounted using the formula,

$$
\mathrm{WTP}_{\mathrm{PV}}=\sum_{n=1}^{4} \mathrm{WTP}_{\mathrm{FV}}\left[\frac{1}{(1+\delta)^{n}}\right],
$$

where $W T P_{P V}$ is the present value WTP of future WTP payments, $\mathrm{WTP}_{F V}$ is the sum of five future value WTP estimates at year zero for in-state clean-up, $\delta$ is the selected discount rate and $n$ is the number of years WTP is discounted. A respondent WTP for instate clean-up can be written as:

$$
\mathrm{WTP}_{\mathrm{ri}}=\mathrm{WTP}_{\mathrm{rPV}},
$$

where $\mathrm{WTP}_{\mathrm{ri}}$ is equal a respondent WTP for in-state clean-up for five years discounted using equation (3-6). To calculate in-state WTP for a non-respondent:

$$
\mathrm{WTP}_{\mathrm{ni}}=\mathrm{WTP}_{\mathrm{nPV}},
$$

where $\mathrm{WTP}_{\mathrm{ni}}$ is equal a non-respondent WTP for in-state clean-up for five years discounted using equation (3-6). Because out-of-state payments were phrased as a one- 
time donation, no discounting of this payment was needed. WTP by a respondent for outof-state clean-up is equal to,

$$
\mathrm{WTP}_{\mathrm{ro}}=\mathrm{WTP}_{\mathrm{r}}
$$

where $\mathrm{WTP}_{\text {ro }}$ is equal a respondent WTP for out-of-state clean-up. WTP by a nonrespondent for out-of-state clean-up is equal to,

$$
\mathrm{WTP}_{\text {no }}=\mathrm{WTP}_{\mathrm{n}}
$$

where $\mathrm{WTP}_{\text {no }}$ is equal a non-respondent WTP for out-of-state clean-up.

To aggregate household WTP estimates, three scenarios were created which reflected a range of aggregate WTP possibilities (Table 3.5). This method of analysis was also completed to control for the possibility of non-response error.

Table 3.5- Summary of Scenarios to Reflect the Range of Aggregate WTP Possibilities.

\begin{tabular}{|l|ll|}
\hline Scenario & & \multicolumn{1}{c|}{ Description } \\
\hline High & $\bullet$ & $\begin{array}{l}\text { Respondents and non-respondents are assumed to have the same WTP } \\
\text { found by using sample information and the grouped tobit model. } \\
\bullet\end{array}$ \\
\hline Medium & $\begin{array}{l}\text { Survey demographics are assumed the same as the watershed } \\
\text { demographics. }\end{array}$ \\
& $\begin{array}{l}\text { Respondents and non-respondents are assumed to have a different WTP, } \\
\text { separately estimated by using the grouped tobit model. }\end{array}$ \\
& $\begin{array}{l}\text { Survey demographics are not assumed the same as the watershed } \\
\text { demographics. }\end{array}$ \\
& $\begin{array}{l}\text { Respondent WTP estimated using sample observations while non- } \\
\text { coefficient estimates and watershed Census statistics. } \\
\text { The proportion of households that represent respondent WTP is equal to } \\
\text { the overall survey response rate and the proportion of households that } \\
\text { represent non-respondent WTP is equal to the overall survey non- } \\
\text { response rate. }\end{array}$ \\
\hline Low & $\begin{array}{l}\text { Respondent WTP estimated by using sample information and the } \\
\text { grouped tobit model. } \\
\text { Non-respondents are assumed to have a zero WTP. } \\
\text { The proportion of households that represent respondent WTP is equal to } \\
\text { the overall survey response rate and the proportion of households that } \\
\text { represent non-respondent WTP are assumed to have a zero WTP. }\end{array}$ \\
\hline
\end{tabular}


These scenarios differed by their underlying assumptions and are known as Low, Medium and High. Although the assumptions differed, all three scenarios used grouped tobit median estimated WTP. Median WTP estimates were chosen because of their conservative properties. These scenarios were created on the aggregate level in part to control for the possibility of survey unit non-response. These scenarios also allow for non-respondents to be treated differently than respondents. Treating non-respondents differently than respondents enables WTP to be calculated for both respondents and nonrespondents. In addition, because survey response rates could be low with one large sample, this type of analysis is necessary.

The first scenario by which WTP estimates were projected to the population was to assume that sample respondents represent the watershed population. This scenario is known as the High scenario. Given a low response rate and a possibility of differences between watershed Census demographics and survey demographics, this scenario would more than likely over estimate the total economic benefits of improved water quality. To obtain total WTP values under the High scenario, median WTP estimates would be multiplied by the total number of households within the state zip codes. This can be represented by:

$$
\mathrm{WTP}_{\mathrm{TH}}=\sum_{i=1}^{j}\left(W T P_{r i}+W T \mathrm{P}_{\mathrm{ro}}\right),
$$

where $W_{T P} P_{T H}$ is the total WTP for improved water quality in the entire watershed, $W T P_{r i}$ is the median household WTP by respondents for in-state clean-up, $W T P_{r o}$ is the median household WTP by respondents for out-of-state clean-up, $j$ is equal to the total number of households within the watershed. Under this scenario, the assumption is that the sample 
contains the same percentage of supporters and/or individuals opposed to the restoration project as in the population.

A second scenario that WTP estimates were aggregated to the population is to assume that sub-sample respondents represented the same percentage of households in the population. Non-respondents were assumed to have a positive WTP different than respondents. As previously discussed, this statistical method was employed to control for the possibility of non-response error. This scenario is known as the Medium scenario and most likely represents the closest estimate of the total economic benefits for improved water quality within Opequon watershed. Respondent WTP represented the total number of households' times the survey response rate. It was then assumed that non-respondent households had a WTP value which was estimated through the use of grouped tobit model coefficients, imputed values and watershed Census data. Because the VARL subsample obtained higher response rates compared to the general public sub-samples, nonrespondent WTP values were not estimated for riparian landowners. These assumptions can be represented by:

$$
\mathrm{WTP}_{\mathrm{TM}}=\sum_{i=1}^{k}\left(W T P_{r i}+W T P_{n i}\right)+\sum_{o=1}^{m}\left(W T P_{r o}+W T P_{n o}\right),
$$

where $W_{T P} P_{T M}$ is the total WTP for improved water quality within Opequon watershed using Medium scenario assumptions, $W T P_{r i}$ is the total median household WTP by respondents for in-state clean-up, $W T P_{n i}$ is the total median household WTP by nonrespondents for in-state clean-up, $W T P_{r o}$ is the median household WTP by respondents for out-of-state clean-up, $W T P_{n o}$ is the median household WTP by non-respondents for out-of-state clean-up, $k$ is the proportion of households that represent respondents, $m$ is the proportion of households that represent non-respondents. 
The third scenario by which WTP estimates were projected to the population was to assume that respondents represented the survey response rate of the population and that non-respondents had zero WTP for improved water quality within Opequon watershed. This is known as the Low scenario and is the most conservative scenario. These assumptions can be represented by:

$$
\mathrm{WTP}_{\mathrm{TL}}=\sum_{i=1}^{k}\left(W T P_{r i}+W T P_{r o}\right),
$$

where $W T P_{T L}$ is the total WTP for improved water quality within Opequon watershed using Low scenario assumptions, $W T P_{r i}$ is the total median household WTP by respondents for in-state clean-up, $W T P_{r o}$ is the total median household WTP by respondents for out-of-state clean-up, $k$ is the proportion of households that represent respondents in the watershed.

After all assumptions were made, WTP estimates were projected to the population for in-state and out-of-state clean-up resulting in the total economic benefits of improving water quality within Opequon watershed. 


\subsection{Results}

Results were obtained from a contingent valuation (CV) survey instrument that was mailed during the middle of August and the first two weeks of September 2005. This survey was administered by mail to general public residents of selected zip codes within the Virginia and West Virginia portions of Opequon watershed. Results were also obtained from a mailing to randomly selected Virginia riparian landowners on Opequon or Abrams Creeks. Results were received from the first of September 2005 through end of February 2006.

\subsection{Survey Response Rates}

Mail survey response rates were calculated from a total of 625 completed survey questionnaires. This includes a total of 230 questionnaires from Virginia general public (VAGP) residents, 332 questionnaires from West Virginia general public (WVGP) residents and 63 questionnaires from Virginia riparian landowner (VARL) households. Response rates for each sub-sample are summarized in Table 4.1. Throughout this section, results will be discussed for all three sub-samples: WVGP, VAGP and VARL households.

Although 5,000 surveys were mailed, approximately 4,961 were able to be delivered to their correct address. This was because of surveys being returned as undeliverable or the passing away of possible respondents. The overall response rate was fairly low, approximately 13\%, although a fairly high number of completed surveys were returned (625). The response rate is on the low end when examining previous, similar CV surveys found in Table 2.1. This low response rate could be attributed to only one mailing to all WVGP and VAGP households. In addition, the large initial sample 
contributed to this. The response rate for VARL households was approximately $36 \%$.

One possible reason for a higher response rate for this sub-sample, compared to the general public, is because of a second mailing of survey instruments. Approximately 20 additional VARL questionnaires were received because of this second round of survey distribution (approximately one-third of total responses).

Table 4.1- Summary of Survey Response Rates.

\begin{tabular}{|l|c|c|c|c|c|c|}
\hline Sub-sample & $\begin{array}{c}\text { Initial } \\
\text { mailing }\end{array}$ & $\begin{array}{c}\text { Surveys } \\
\text { returned as } \\
\text { undeliverable }\end{array}$ & $\begin{array}{c}\text { Surveys } \\
\text { returned for } \\
\text { some other } \\
\text { reason }\end{array}$ & $\begin{array}{c}\text { Total } \\
\text { sample }\end{array}$ & $\begin{array}{c}\text { Total } \\
\text { returned }\end{array}$ & $\begin{array}{c}\text { Response } \\
\text { rate } \\
(\%)\end{array}$ \\
\hline WVGP & 2,500 & 10 & 3 & 2,487 & 332 & 13 \\
\hline VAGP & 2,300 & 0 & 3 & 2,297 & 230 & 10 \\
\hline VARL & 200 & 23 & 0 & 177 & 63 & 36 \\
\hline Total & 5,000 & 33 & 6 & 4,961 & 625 & 13 \\
\hline
\end{tabular}

\subsection{Survey Demographics}

Once all mail survey questionnaires were received, respondents were compared to watershed population statistics from the 2000 Census (United States Census Bureau, 2000). Table 4.2 summarizes the comparison between WVGP respondents and 2000 Census data. WVGP respondents consisted of more male respondents, who were older, better educated, and with higher incomes compared to Census statistics. Also, more WVGP respondents owned their own housing unit compared to Census statistics.

Table 4.2- Summary of Comparing West Virginia Respondents to Census Data.

\begin{tabular}{|l|c|c|c|c|c|}
\hline & Male & $\begin{array}{c}\text { Median } \\
\text { age } \\
\text { (years) }\end{array}$ & $\begin{array}{c}\text { Bachelor } \\
\text { degree or } \\
\text { higher }\end{array}$ & $\begin{array}{c}\text { Owner occupied } \\
\text { housing units }\end{array}$ & $\begin{array}{c}\text { Income } \\
\text { greater than } \\
\$ 50,000\end{array}$ \\
\hline $\begin{array}{l}\text { WV watershed } \\
\text { population }\end{array}$ & $49.5 \%$ & 36.0 & $15.0 \%$ & $71.4 \%$ & $35.3 \%$ \\
\hline $\begin{array}{l}\text { WVGP } \\
\text { respondents }\end{array}$ & $69.0 \%$ & 52.0 & $40.0 \%$ & $84.0 \%$ & $51.0 \%$ \\
\hline
\end{tabular}

Similar results were obtained when comparing VAGP respondents to Census data (United States Census Bureau, 2000) (Table 4.3). VAGP respondents and VARL 
respondents also consisted of more male respondents, who were older, better educated and had higher incomes. More of these respondents also owned their own housing unit compared to Census statistics.

Table 4.3- Summary of Comparing Virginia Respondents to 2000 Census Data.

\begin{tabular}{|l|c|c|c|c|c|}
\hline & Male & $\begin{array}{c}\text { Median age } \\
\text { (years) }\end{array}$ & $\begin{array}{c}\text { Bachelor } \\
\text { degree or } \\
\text { higher }\end{array}$ & $\begin{array}{c}\text { Owner } \\
\text { occupied } \\
\text { housing units }\end{array}$ & $\begin{array}{c}\text { Income } \\
\text { greater than } \\
\$ 50,000\end{array}$ \\
\hline $\begin{array}{l}\text { VA watershed } \\
\text { population }\end{array}$ & $49.2 \%$ & 36.0 & $21.6 \%$ & $61.8 \%$ & $39.0 \%$ \\
\hline $\begin{array}{l}\text { VAGP } \\
\text { respondents }\end{array}$ & $60.0 \%$ & 51.0 & $53.0 \%$ & $79.0 \%$ & $53.0 \%$ \\
\hline $\begin{array}{l}\text { VARL } \\
\text { respondents }\end{array}$ & $56.0 \%$ & 54.0 & $57.0 \%$ & $84.0 \%$ & $72.0 \%$ \\
\hline
\end{tabular}

Differences can be found between sub-samples when comparing WVGP respondents to VAGP respondents. WVGP respondents consisted of more male respondents, who were slightly older, with less education and with generally lower incomes, compared to VAGP respondents. Differences can also be found when comparing VARL respondents and VAGP respondents. Compared to VAGP respondents, VARL respondents consisted of slightly more female respondents, who were older, with more education and with higher incomes. In addition to this, more VARL households owned their occupied housing unit compared to VAGP respondents. When comparing Census data between West Virginia and Virginia residents, similarities are found with regard to gender and age. When examining education and income, West Virginia has slightly fewer college educated residents with slightly lower incomes. However, more West Virginians own their own housing unit compared to Virginians.

\subsection{Survey Responses}

Summary statistics were computed for individual responses to all questions on the distributed survey instrument. Table 4.4 compares results for selected questions. 
Table 4.4- Summary of Selected Questions from General Public Respondents. ${ }^{17}$

\begin{tabular}{|c|c|c|}
\hline Question & $\begin{array}{c}\text { West } \\
\text { Virginia } \\
(\mathrm{N}=332)\end{array}$ & $\begin{array}{l}\text { Virginia } \\
(\mathrm{N}=230)\end{array}$ \\
\hline $\begin{array}{l}\text { 1. With what portions of Opequon Creek, if any, are you } \\
\text { familiar? }\end{array}$ & Percentage & Percentage \\
\hline The portion of Opequon Creek in Virginia. & $13 \%$ & $79 \%$ \\
\hline The portion of Opequon Creek in West Virginia. & $79 \%$ & $9 \%$ \\
\hline Not familiar with any portion of Opequon Creek. & $18 \%$ & $23 \%$ \\
\hline $\begin{array}{l}\text { 2. Have you ever used Opequon Creek for fishing, } \\
\text { swimming, wading, hiking along, exploring, wildlife } \\
\text { watching, kayaking or canoeing? }\end{array}$ & Percentage & Percentage \\
\hline Yes & $64 \%$ & $53 \%$ \\
\hline No & $36 \%$ & $47 \%$ \\
\hline $\begin{array}{l}\text { 3. Based upon what you know about Opequon Creek, do } \\
\text { you think there are environmental problems associated } \\
\text { with this creek? }\end{array}$ & Percentage & Percentage \\
\hline Yes & $71 \%$ & $60 \%$ \\
\hline No & $2 \%$ & $4 \%$ \\
\hline Don't know & $27 \%$ & $36 \%$ \\
\hline $\begin{array}{l}\text { 4. If you answered "Yes" in Question 3, what } \\
\text { environmental problems are you aware of on Opequon } \\
\text { and/or Abrams Creeks? }\end{array}$ & Percentage & Percentage \\
\hline Trash & $86 \%$ & $81 \%$ \\
\hline Livestock & $42 \%$ & $49 \%$ \\
\hline Lack of recreational opportunities & $34 \%$ & $27 \%$ \\
\hline Flooding and/or storm water runoff & $52 \%$ & $47 \%$ \\
\hline Sewage & $58 \%$ & $32 \%$ \\
\hline Dirt/Sediment & $52 \%$ & $54 \%$ \\
\hline $\begin{array}{l}\text { 5. How concerned are you about the ability of fish and } \\
\text { other aquatic life to survive in Opequon Creek? }\end{array}$ & Percentage & Percentage \\
\hline Very concerned. & $57 \%$ & $46 \%$ \\
\hline Some what concerned. & $39 \%$ & $48 \%$ \\
\hline Not concerned at all. & $4 \%$ & $6 \%$ \\
\hline $\begin{array}{l}\text { 8. In the past few years, what would you say has happened } \\
\text { to the overall quality of the environment in your area? }\end{array}$ & Percentage & Percentage \\
\hline Improved & $2 \%$ & $2 \%$ \\
\hline Stayed the same & $17 \%$ & $18 \%$ \\
\hline Gotten worse & $75 \%$ & $69 \%$ \\
\hline Don't know & $6 \%$ & $11 \%$ \\
\hline
\end{tabular}

\footnotetext{
${ }^{17}$ The wording of questions varied slightly between WVGP and VAGP sub-samples which make comparisons not exactly identical.
} 


\begin{tabular}{|l|c|c|}
\hline Question & $\begin{array}{c}\text { West } \\
\text { Virginia } \\
(\mathrm{N}=332)\end{array}$ & $\begin{array}{c}\text { Virginia } \\
(\mathrm{N}=230)\end{array}$ \\
\hline $\begin{array}{l}\text { 11. After cleaning up Opequon Creek, what other } \\
\text { improvements, if any, would you like to see along this } \\
\text { creek? }\end{array}$ & Percentage & Percentage \\
\hline Walking or biking trails. & $59 \%$ & $61 \%$ \\
\hline Public access for fishing and recreation. & $58 \%$ & $44 \%$ \\
\hline Regular trash clean-up. & $80 \%$ & $71 \%$ \\
\hline Fish stocking & - & $43 \%$ \\
\hline Protection of forests along the creek. & $69 \%$ & $66 \%$ \\
\hline None & $3 \%$ & $4 \%$ \\
\hline Other & $5 \%$ & $5 \%$ \\
\hline
\end{tabular}

In West Virginia, the majority of respondents were familiar with at least one portion of Opequon Creek. In addition to this, the majority of respondents had used Opequon Creek for a stated type of recreational activity and thought that there were environmental problems associated with this creek. Nearly all respondents were at least somewhat concerned about the ability of fish and other aquatic life to survive in Opequon Creek. Very few respondents thought that the overall quality of the environment had improved in the past few years, with the majority stating that it had gotten worse. Respondents revealed that they most preferred regular trash clean-ups as an improvement in Opequon watershed. This improvement was followed by protection of forests along the creek.

Among VAGP respondents, the majority of respondents were familiar with at least one portion of Opequon watershed in Virginia. Approximately half of VAGP respondents had used Opequon or Abrams Creeks for a specified recreational activity. Very few respondents shared the opinion that there were no environmental problems associated with these creeks and that they were not at all concerned about the ability of fish and other aquatic life to survive in Opequon or Abrams Creeks. Also, very few 
respondents thought that the overall quality of the environment had improved in the past few years and the majority stated that it had gotten worse. As in West Virginia, respondents revealed that they most preferred regular trash clean-ups followed by protection of forests along the creek as the top two improvements in Opequon watershed. The majority (86\%) of VAGP respondents were unaware that a Total Maximum Daily Load (TMDL) had been developed for creeks in this watershed.

Selected question results by VARL households were also analyzed (Table 4.5). VARL households were found to be most concerned about general stream pollution when asked about their concerns regarding the creek or stream running through or adjacent to their property. This response was followed by trash in the stream or creek. Almost all respondents in this sub-sample were found to be familiar with some portion of Opequon or Abrams Creeks. The majority of VARL respondents had used Opequon or Abrams Creeks for a specified recreational activity. In addition, the majority of VARL respondents shared the opinion that there are environmental problems associated with Opequon or Abrams creeks. Almost all respondents were very or somewhat concerned about the ability of fish and other aquatic life to survive in these creeks. Approximately one-third of VARL respondents were aware of the TMDL that has been developed for this watershed. Very few VARL respondents thought that the overall quality of the environment had improved in their area. 
Table 4.5- Summary of Selected Questions from Virginia Riparian Landowner Respondents.

\begin{tabular}{|l|c|}
\hline Question & $\begin{array}{c}\text { Riparian } \\
\text { landowner } \\
\text { respondents } \\
\text { (N=63) }\end{array}$ \\
\hline $\begin{array}{l}\text { 1. Which of the following concerns do you have about this stream or } \\
\text { creek? }\end{array}$ & Percentage \\
\hline Stream pollution & $85 \%$ \\
\hline Stream bank erosion & $43 \%$ \\
\hline Stream course changes & $21 \%$ \\
\hline Trash in the stream & $66 \%$ \\
\hline Flooding & $38 \%$ \\
\hline Wildlife & $38 \%$ \\
\hline Recreational users & $17 \%$ \\
\hline $\begin{array}{l}\text { 4. With what portions of Opequon and Abrams Creeks, if any, are you } \\
\text { familiar? }\end{array}$ & Percentage \\
\hline Upper portion of Opequon Creek. & $48 \%$ \\
\hline Abrams Creek & $48 \%$ \\
\hline Lower portion of Opequon Creek. & $29 \%$ \\
\hline West Virginia portion of Opequon Creek. & $11 \%$ \\
\hline $\begin{array}{l}\text { 5. Have you ever used Opequon or Abrams Creeks for fishing, } \\
\text { swimming, wading, hiking along, exploring, wildlife watching, } \\
\text { kayaking or canoeing? }\end{array}$ & Percentage \\
\hline Yes & $63 \%$ \\
\hline No & $37 \%$ \\
\hline $\begin{array}{l}\text { 6. Based upon what you know about Opequon and Abrams Creeks, do } \\
\text { you think there are environmental problems associated with these } \\
\text { creeks? }\end{array}$ & Percentage \\
\hline Yes & $77 \%$ \\
\hline No & $5 \%$ \\
\hline Don't know & $18 \%$ \\
\hline $\begin{array}{l}\text { 8. How concerned are you about the ability of fish and other aquatic life } \\
\text { to survive in Opequon and Abrams Creeks? }\end{array}$ & Percentage \\
\hline Very concerned. & $46 \%$ \\
\hline Some what concerned. & $42 \%$ \\
\hline Not concerned at all. & $12 \%$ \\
\hline $\begin{array}{l}\text { 9. Are you aware that a TMDL has been developed for Opequon and } \\
\text { Abrams Creeks? }\end{array}$ & Percentage \\
\hline Yes & $30 \%$ \\
\hline No & $60 \%$ \\
\hline
\end{tabular}




\begin{tabular}{|l|c|}
\hline Question & $\begin{array}{c}\text { Riparian } \\
\text { landowner } \\
\text { respondents } \\
\text { (N=63) }\end{array}$ \\
\hline $\begin{array}{l}\text { 12. In the past few years, what would you say has happened to the } \\
\text { overall quality of the environment in your area? }\end{array}$ & Percentage \\
\hline Improved & $6 \%$ \\
\hline Stayed the same & $24 \%$ \\
\hline Gotten worse & $60 \%$ \\
\hline Don't know & $10 \%$ \\
\hline
\end{tabular}

From the responses, differences can be observed between the three sub-samples. VARLs were found to be slightly more familiar with sections of Opequon Creek than VAGP respondents. VARL respondents also stated that they used the creeks for recreation slightly more than VAGP respondents but approximately equal to WVGP respondents. Having more recreational opportunities in West Virginia than Virginia, may be one reason for this finding. In addition to this, this result can be attributed to riparian landowners close proximity to the creeks. Compared to VAGP responses, VARL households were found to be more aware of the TMDLs developed for this watershed. Also, compared to responses from the VAGP, VARLs had a better opinion regarding the overall quality of the environment.

\subsection{Household Results to the Contingent Valuation Question}

\subsubsection{Survey Results ${ }^{18}$}

Approximately $69 \%$ of all WVGP respondents were in support of the in-state water quality improvement plan. Approximately $11 \%$ opposed the clean-up plan and $20 \%$ remained neutral or would not participate in the vote. For all WVGP respondents, annual monetary response values for in-state clean-up ranged from $\$ 0$ to $\$ 500$ for five years (Figure 4.1). The annual mean monetary response value for in-state clean-up by all

\footnotetext{
${ }^{18}$ The results described in this sub-section are for all survey respondents including protest respondents.
} 
WVGP respondents was approximately $\$ 34$ while the median value for these respondents and clean-up plan was $\$ 15$.

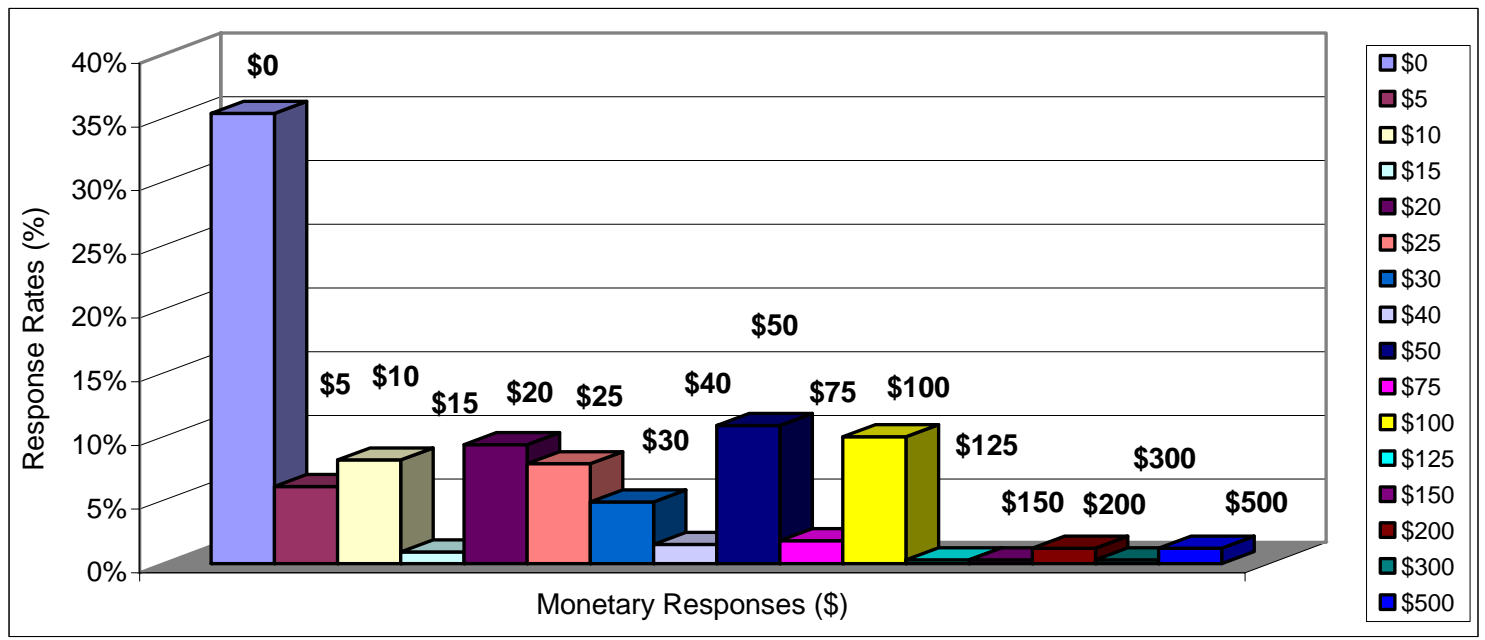

Figure 4.1- Distribution of monetary responses by WVGP respondents for In-state Clean-up.

Of those WVGP respondents who opposed or remained neutral about the cleanup, approximately half stated that they support the clean-up of Opequon Creek in West Virginia but cannot afford higher taxes. Approximately one third of these same respondents support the clean-up of Opequon Creek but think taxes are not the best way to pay for it (Figure 4.2).

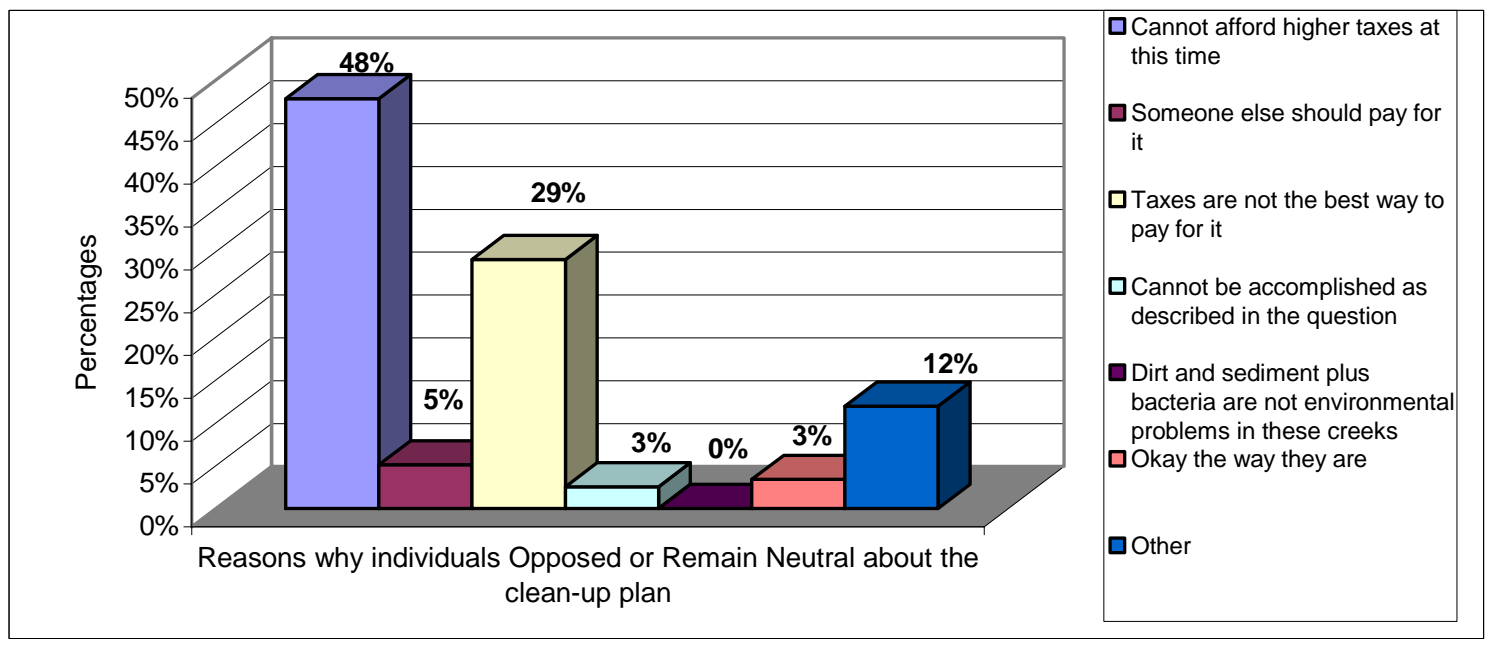

Figure 4.2- Distribution of reasons why Individuals in West Virginia Opposed or Remain Neural/Not Participate in Funding the In-state Clean-up. 
Approximately $70 \%$ of all VAGP respondents were in support of the in-state water quality improvement plan. Approximately $11 \%$ opposed the clean-up plan and $17 \%$ remained neutral or would not participate in the vote. For all VAGP respondents, annual monetary response values for in-state clean-up ranged from $\$ 0$ to $\$ 1,000$ for five years (Figure 4.3). The annual mean monetary response value for in-state clean-up by all VAGP respondents was approximately $\$ 48$ while the median value for these respondents and clean-up plan was $\$ 20$.

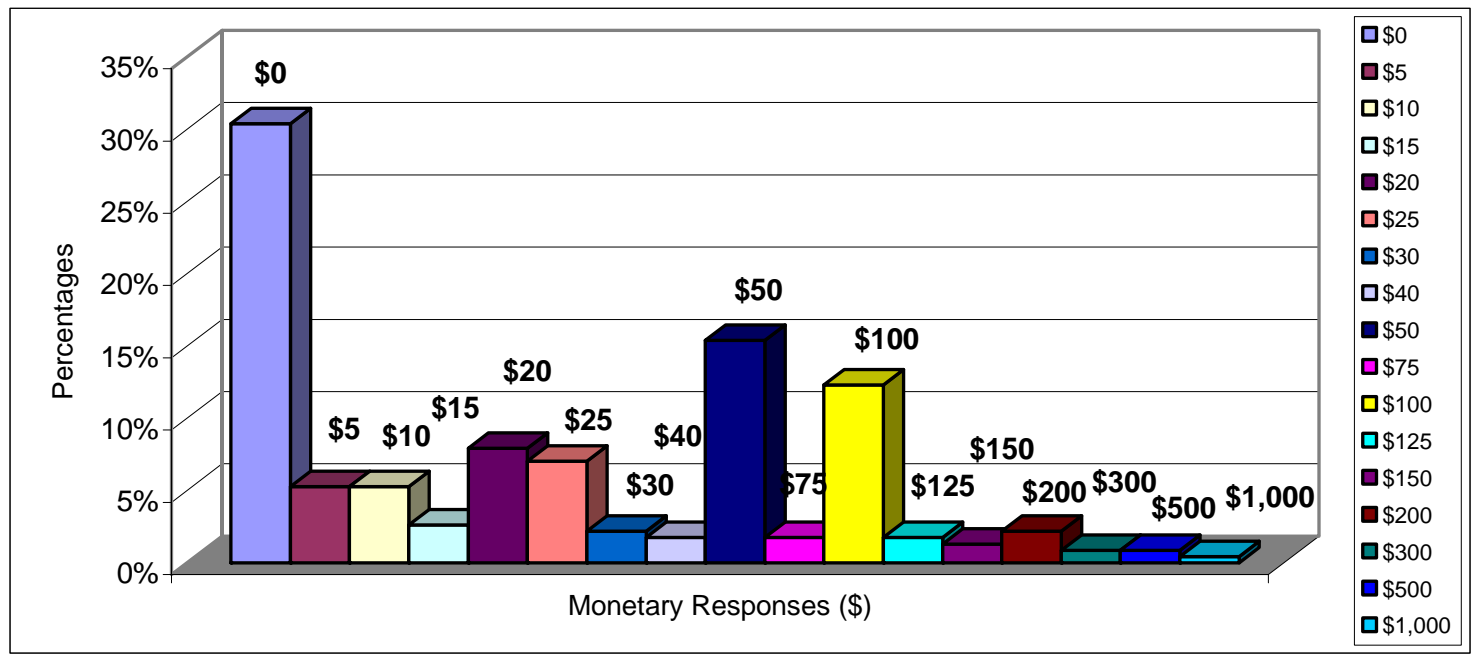

Figure 4.3- Distribution of monetary responses by VAGP respondents for In-state Cleanup.

Of those VAGP respondents who opposed or remained neutral about the clean-up, almost half stated that they support the clean-up of Opequon and Abrams Creeks in Virginia but cannot afford higher taxes. Approximately one fifth stated they support the clean-up of Opequon and Abrams Creeks in Virginia but think that taxes are not the best way to pay for it (Figure 4.4). 


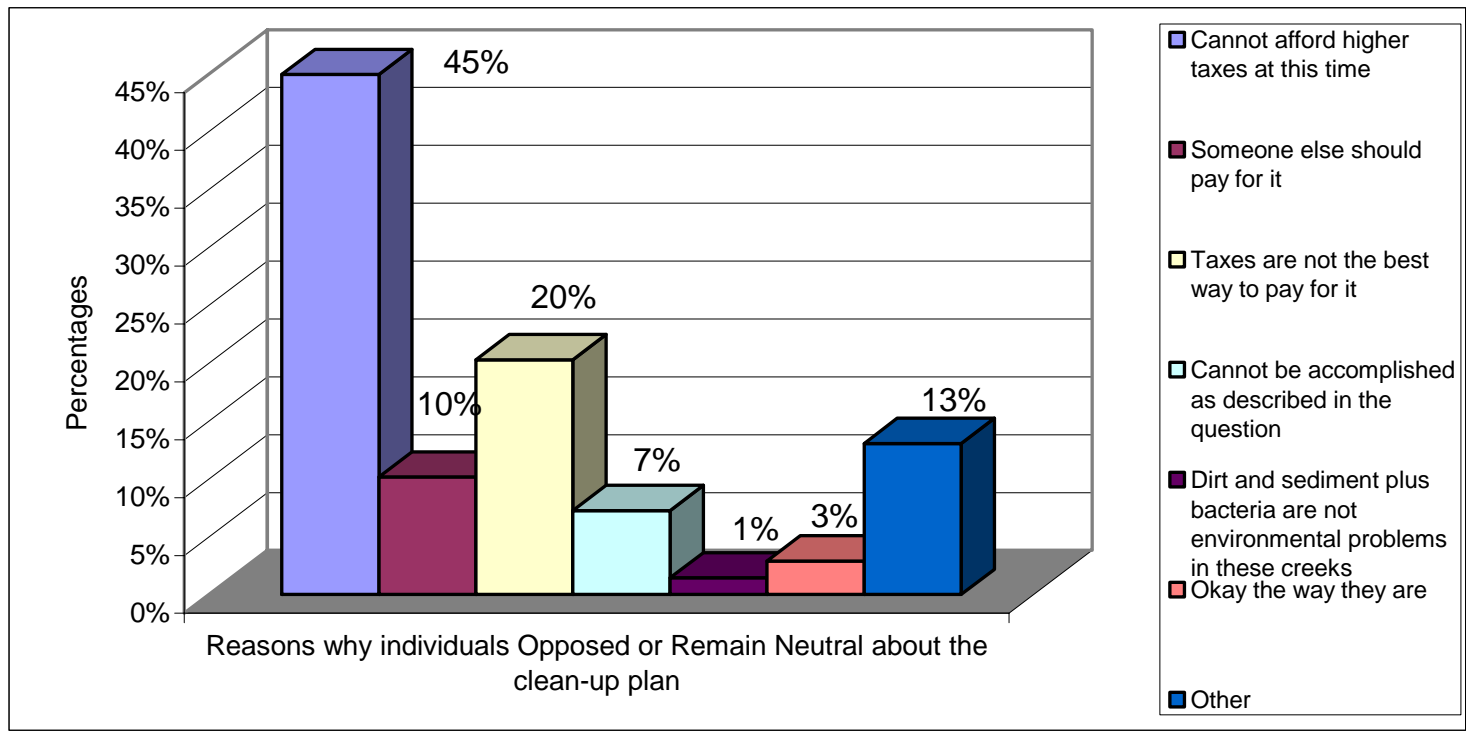

Figure 4.4- Distribution of reasons why Individuals in Virginia Opposed or Remain Neural/Not Participate in Funding the In-state Clean-up.

Over two-thirds of all VARL respondents were in support of the in-state water quality improvement plan. Approximately one-third opposed or remained neutral/would not participate in the vote. For all VARL respondents, annual monetary response values for in-state clean-up ranged from $\$ 0$ to $\$ 300$ for five years (Figure 4.5). The annual mean monetary response value for in-state clean-up by all VARL respondents was approximately $\$ 54$ while the median value for these respondents and clean-up plan was $\$ 25$. 


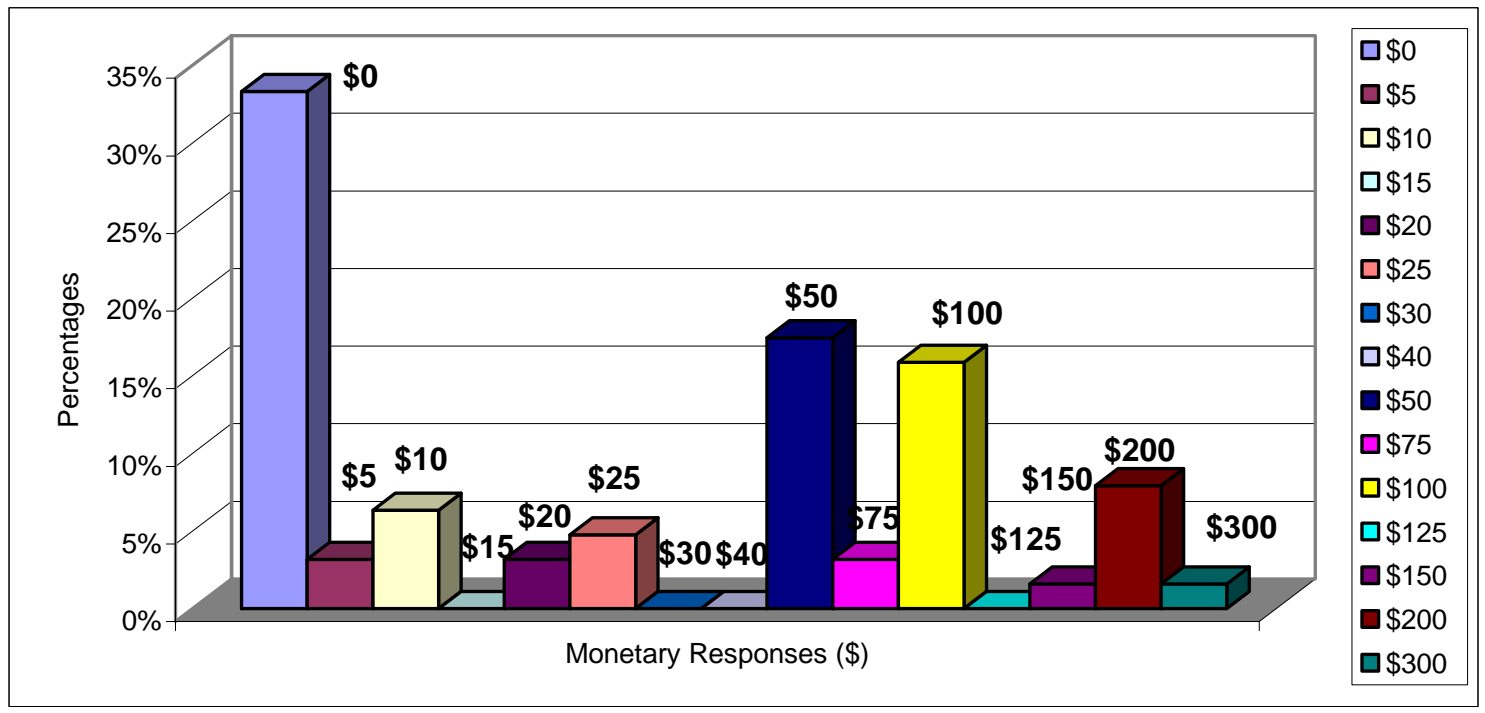

Figure 4.5- Distribution of monetary responses by VARL respondents for In-state Cleanup.

Of those VARL respondents who opposed or remained neutral about the clean-up, approximately one half stated that they support the clean-up of Opequon and Abrams Creeks in Virginia but cannot afford higher taxes. Approximately one quarter of these same respondents stated that they support the clean-up of Opequon and Abrams Creeks in Virginia but think that taxes are not the best way to pay for it (Figure 4.6).

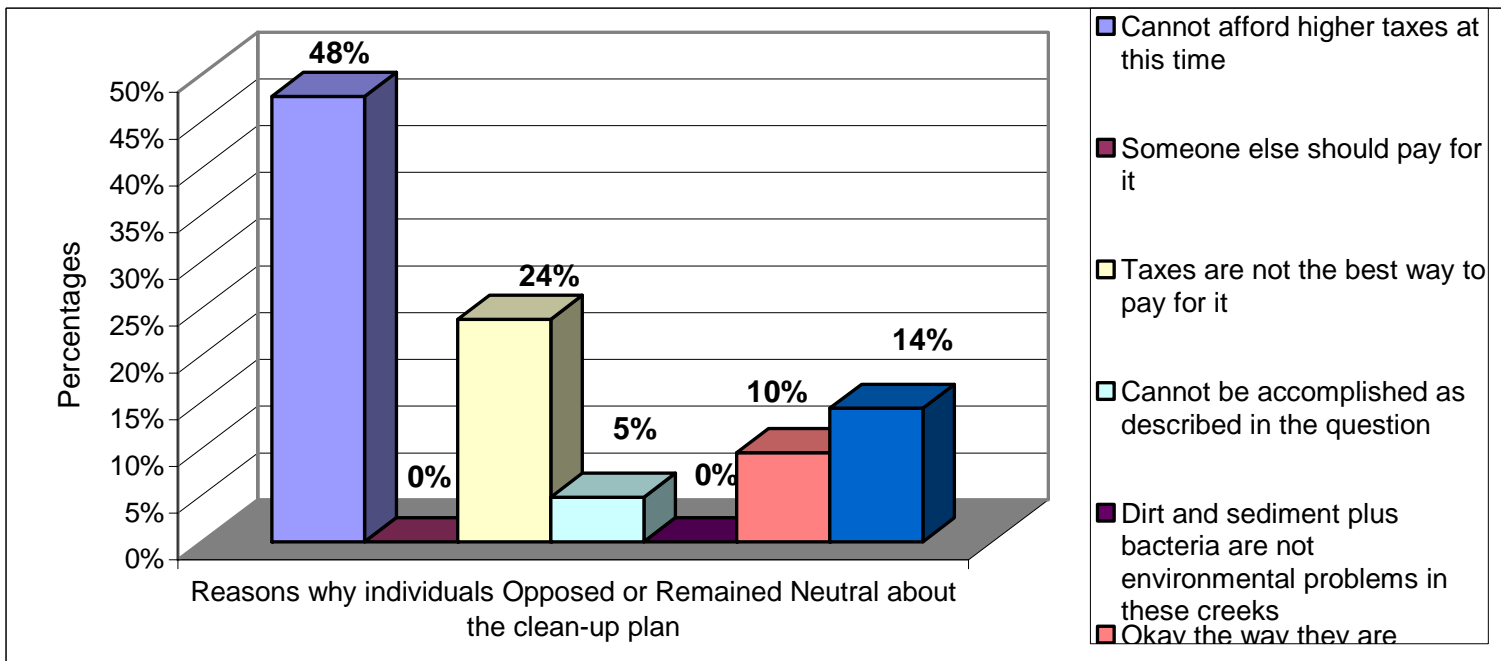

Figure 4.6- Distribution of reasons why Virginia Riparian Landowners Opposed or Remain Neural/Not Participate in Funding the In-state Clean-up. 
Approximately $67 \%$ of all VAGP and WVGP respondents had a positive monetary response for the out-of-state water quality improvement plan. Approximately $54 \%$ of all VARL respondents had a positive monetary response for the out-of-state water quality improvement plan. For all three sub-samples, no individual respondent was willing to donate more than $\$ 500$ to the clean-up fund for out-of-state improvements. The mean one-time donation response value for out-of-state clean-up by all VAGP respondents was approximately $\$ 29$, while the median value was $\$ 10$. The mean one-time donation response value for out-of-state clean-up by all WVGP respondents was approximately $\$ 38$, while the median value was $\$ 10$. The mean one-time donation response value for out-of-state clean-up by all VARL respondents was approximately $\$ 29$. VARL respondents were found to have a median one-time response value of $\$ 0$ (Table 4.6).

Table 4.6- Summary of Survey Monetary Responses by Sub-Sample and Clean-up Plan.

\begin{tabular}{|l|c|c|c|c|}
\hline & \multicolumn{2}{|c|}{ In-state } & \multicolumn{2}{c|}{ Out-of-state } \\
\hline Sub-sample & Mean & Median & Mean & Median \\
\hline VAGP $(\mathrm{N}=230)$ & $\$ 48$ & $\$ 20$ & $\$ 29$ & $\$ 10$ \\
\hline WVGP $(\mathrm{N}=332)$ & $\$ 34$ & $\$ 15$ & $\$ 38$ & $\$ 10$ \\
\hline VARL $(\mathrm{N}=63)$ & $\$ 54$ & $\$ 25$ & $\$ 29$ & $\$ 0$ \\
\hline
\end{tabular}

\subsubsection{Grouped Tobit Model Results}

The econometric modeling process began by developing grouped tobit models to determine if general public sub-samples were similar enough to be combined into one pooled data set. Selected questions were compared on the basis of log-likelihood ratio (LLR) tests. These comparisons were done using WTP for in-state clean-up as the dependent variable. Table 4.7 summarizes the results when comparing VAGP and WVGP respondents. 
Table 4.7- Summary of Grouped Tobit Model Results when comparing WTP for In-State Clean-up by VAGP and WVGP Sub-samples. ${ }^{\text {a }}$

\begin{tabular}{|c|c|c|c|c|c|c|}
\hline Variable & $\begin{array}{c}\text { WVGP } \\
\text { coefficient } \\
\text { estimate }\end{array}$ & $\begin{array}{c}\text { WVGP } \\
\text { (SE) }\end{array}$ & $\begin{array}{c}\text { VAGP } \\
\text { coefficient } \\
\text { estimate }\end{array}$ & $\begin{array}{c}\text { VAGP } \\
\text { (SE) }\end{array}$ & $\begin{array}{c}\text { Pooled } \\
\text { coefficient } \\
\text { estimate }\end{array}$ & $\begin{array}{c}\text { Pooled } \\
\text { (SE) }\end{array}$ \\
\hline Constant & $2.2552^{* * *}$ & $(0.36)$ & $1.7352^{* * *}$ & $(0.414)$ & $2.1512^{* * *}$ & $(0.278)$ \\
\hline USE & $0.5617^{* * *}$ & $(0.175)$ & $0.4814^{* * *}$ & $(0.175)$ & $0.4925^{* * *}$ & $(0.126)$ \\
\hline GENPROB & 0.1291 & $(0.192)$ & -0.0337 & $(0.215)$ & 0.0407 & $(0.143)$ \\
\hline DIRTSED & 0.0621 & $(0.155)$ & -0.2048 & $(0.19)$ & -0.019 & $(0.122)$ \\
\hline CONCERN & 0.1712 & $(0.138)$ & $0.3045^{* *}$ & $(0.152)$ & $0.2049^{*}$ & $(0.105)$ \\
\hline FISH & -0.1239 & $(0.16)$ & 0.1241 & $(0.184)$ & -0.0466 & $(0.122)$ \\
\hline QUALITY & -0.6481 & $(0.442)$ & -1.0879 & $(0.707)$ & $-0.8952^{*}$ & $(0.377)$ \\
\hline PUBACC & -0.1483 & $(0.142)$ & -0.0584 & $(0.16)$ & -0.1261 & $(0.109)$ \\
\hline DISTRUST & 0.054 & $(0.13)$ & $0.3007^{*}$ & $(0.154)$ & 0.1512 & $(0.101)$ \\
\hline GENDER & 0.1865 & $(0.152)$ & -0.0141 & $(0.16)$ & 0.098 & $(0.11)$ \\
\hline$A G E$ & $0.0129^{* * * *}$ & $(0.005)$ & $0.0144^{* *}$ & $(0.006)$ & $0.0119^{* * * *}$ & $(0.004)$ \\
\hline$E D U$ & 0.0338 & $(0.139)$ & $0.4336^{* * *}$ & $(0.157)$ & $0.1886^{*}$ & $(0.106)$ \\
\hline LAND & -0.0436 & $(0.184)$ & -0.0087 & $(0.217)$ & -0.5635 & $(0.141)$ \\
\hline LIFE & $-0.5726^{* * * *}$ & $(0.164)$ & 0.3217 & $(0.202)$ & $-0.2303^{*}$ & $(0.13)$ \\
\hline INCOME & $0.0064^{* * * *}$ & $(0.002)$ & $0.0088^{* * *}$ & $(0.001)$ & $0.008^{* * *}$ & $(0.001)$ \\
\hline Sigma & $0.8337^{* * * *}$ & $(0.047)$ & $0.824^{* * *}$ & $(0.005)$ & $0.8653^{* * *}$ & $(0.037)$ \\
\hline $\begin{array}{l}\text { Log- } \\
\text { likelihood }\end{array}$ & \multicolumn{2}{|c|}{-432.18} & \multicolumn{2}{|c|}{-318.32} & \multicolumn{2}{|c|}{-763.36} \\
\hline
\end{tabular}

When comparing in-state WTP for WVGP and VAGP sub-samples, the log likelihood results were -763.36 for the pooled (WVGP + VAGP), -318.32 for VAGP and -432.18 for WVGP. A test statistic of 25.74 was calculated which is greater than the statistic following the $\chi^{2}$ distribution $\left(\chi_{0.05,14}^{2}=23.685\right)$. Because of this, the null hypothesis cannot be accepted and the two sub-samples cannot be pooled.

Comparing WTP by the VAGP and WVGP sub-samples, differences are observed that show these are separate populations. Variable coefficients for CONCERN, DISTRUST and EDU were found to be statistically significant in determining WTP for in-state clean-up by the VAGP sub-sample but not for the WVGP sub-sample. The variable coefficient for LIFE was found to be statistically significant for the WVGP sub- 
sample but not for the VAGP sub-sample. These differences lead to the creation of separate models for each general public sub-sample when estimating in-state WTP.

Initial grouped tobit models were examined for each general public sub-sample which led to the estimation of a final grouped tobit model. Final grouped tobit models deviated from initial models. Variables found to have low explanatory power were dropped and not included in final models. No quantitative standard was determined for dropping variables but those that seemed less likely to influence a respondent WTP were not included. LIMDEP estimation results for all final grouped tobit models can be found in Appendix 3. Table 4.8 summarizes the results for the initial grouped tobit VAGP instate WTP model.

Table 4.8- Summary of Initial Grouped Tobit Model Results for WTP by VAGP respondents for In-state Clean-up. $(\mathrm{N}=131)^{\mathrm{a}}$

\begin{tabular}{|l|cc|l|cc|}
\hline Variable & $\begin{array}{c}\text { Coefficient } \\
\text { estimate }\end{array}$ & $(\mathrm{SE})$ & Variable & $\begin{array}{l}\text { Coefficient } \\
\text { estimate }\end{array}$ & (SE) \\
\hline Constant & $1.7066^{* * *}$ & $(0.404)$ & DISTRUST & $0.3182^{* *}$ & $(0.153)$ \\
\hline FAMILUP & -0.0431 & $(0.17)$ & GENDER & -0.0669 & $(0.162)$ \\
\hline USE & $0.4642^{* * *}$ & $(0.179)$ & AGE & $0.0159^{* * * *}$ & $(0.006)$ \\
\hline GENPROB & -0.013 & $(0.222)$ & EDU & $0.4744^{* * *}$ & $(0.161)$ \\
\hline DIRTSED & -0.2311 & $(0.194)$ & LAND & -0.0657 & $(0.221)$ \\
\hline CONCERN & $0.3341^{* *}$ & $(0.154)$ & LIFE & $0.415^{* * *}$ & $(0.21)$ \\
\hline TMDL & 0.219 & $(0.218)$ & INCOME & $0.0084^{* * *}$ & $(0.001)$ \\
\hline FISH & 0.1258 & $(0.19)$ & & \multicolumn{2}{c|}{} \\
\hline QUALITY & -1.0668 & $(0.703)$ & Sigma & $0.8182^{* * *}$ & $(0.055)$ \\
\hline FISHSTOC & -0.1002 & $(0.167)$ & Log-likelihood & \multicolumn{2}{c|}{-309.86} \\
\hline
\end{tabular}

${ }^{a}$ Note: ${ }^{*}, * *, * * *$ denote statistical significance at $\mathrm{P}<0.10, \mathrm{P}<0.05, \mathrm{P}<0.01$, respectively.

Table 4.9 summarizes the final grouped tobit model developed for WTP by VAGP respondents for in-state clean-up. In the initial VAGP grouped tobit in-state model (Table 4.8), it was expected that DISTRUST would have a negative sign on the coefficient. However, DISTRUST was found to have a positive coefficient and be statistically significant. The positive sign indicated that those respondents who distrust 
local government to make environmental decisions about the clean-up of Opequon Creek, have a higher WTP for the clean-up plan. This finding did not agree with expectations or intuition. Because of this positive coefficient, a correlation matrix was computed to examine the variable DISTRUST. Examining this correlation matrix led to a logit model that had DISTRUST as the dependent variable. However, this model added little insight to the problem.

Instead, a contingency table was created to examine the variables DISTRUST, TMDL and EDU. From this contingency table it was determined that DISTRUST was being influenced by both $T M D L$ and $E D U$. Both variables $T M D L$ and $E D U$ were found to positively influence one's WTP. Because those individuals who had at least a college degree and were aware of the TMDL also distrusted local government, the variable DISTRUST was obtaining a positive coefficient. In the contingency table, the p-value was stated at approximately 0.08 . Because of this p-value, we can reject the null hypothesis at the $90 \%$ confidence level, concluding that DISTRUST, TMDL and EDU are not independent from one another. This result led us to drop the variable DISTRUST from the final VAGP in-state grouped tobit model. In addition to this, instead of including the single $T M D L$ variable, an interaction variable was created and included, by multiplying $T M D L$ and $E D U$ to create the variable TMDLEDU. 
Table 4.9- Summary of Final Grouped Tobit Model Results for WTP by VAGP respondents for In-state Clean-up. $(\mathrm{N}=131)^{\mathrm{a}}$

\begin{tabular}{|l|cc|l|cc|}
\hline Variable & $\begin{array}{c}\text { Coefficient } \\
\text { estimate }\end{array}$ & $(\mathrm{SE})$ & Variable & $\begin{array}{l}\text { Coefficient } \\
\text { estimate }\end{array}$ & (SE) \\
\hline Constant & $1.9073^{* * *}$ & $(0.4)$ & GENDER & -0.1019 & $(0.156)$ \\
\hline USE & $0.4911^{* * *}$ & $(0.17)$ & AGE & $0.0166^{* * *}$ & $(0.006)$ \\
\hline DIRTSED & -0.2184 & $(0.164)$ & EDU & $0.3970^{* *}$ & $(0.164)$ \\
\hline CONCERN & $0.3848^{* *}$ & $(0.154)$ & LAND & -0.1748 & $(0.221)$ \\
\hline TMDLEDU & $0.5536^{*}$ & $(0.291)$ & LIFE & $0.4549^{* *}$ & $(0.211)$ \\
\hline FISH & 0.0995 & $(0.19)$ & INCOME & $0.0082^{* * *}$ & $(0.001)$ \\
\hline QUALITY & $-1.2084^{*}$ & $(0.693)$ & Sigma & $0.8269^{* * *}$ & $(0.055)$ \\
\hline FISHSTOC & -0.1189 & $(0.168)$ & Log-likelihood & \multicolumn{2}{c|}{-310.76} \\
\hline${ }^{a}$ Note: ${ }^{*},{ }^{* *},{ }^{* * *}$ denote statistical significance at $\mathrm{P}<0.10, \mathrm{P}<0.05, \mathrm{P}<0.01$, respectively. & \\
\hline
\end{tabular}

Virginia general public residents who use the creeks for recreation and are very concerned about the ability of fish or other aquatic life were found to have a higher WTP for improved water quality in the Virginia portion of Opequon watershed. In addition, VAGP respondents who are aware of the TMDL and have at least a college education, have lived with the watershed all their lives and have higher incomes were also found to have a higher WTP for making Opequon and Abrams Creeks swimmable and wadable in Virginia.

To determine if the VARL sub-sample could be pooled with the VAGP subsample, a second LLR test was conducted which compared log likelihood function results from these two sub-samples (Table 4.10) 
Table 4.10- Summary of Grouped Tobit Model Results when comparing WTP for InState Clean-up by VAGP and VARL Sub-samples. ${ }^{\text {a }}$

\begin{tabular}{|c|c|c|c|c|c|c|}
\hline Variable & $\begin{array}{c}\text { VAGP } \\
\text { coefficient } \\
\text { estimate }\end{array}$ & $\begin{array}{l}\text { VAGP } \\
\text { (SE) }\end{array}$ & $\begin{array}{c}\text { VARL } \\
\text { coefficient } \\
\text { estimate }\end{array}$ & $\begin{array}{l}\text { VARL } \\
\text { (SE) }\end{array}$ & $\begin{array}{l}\text { Pooled } \\
\text { coefficient } \\
\text { estimate }\end{array}$ & $\begin{array}{c}\text { Pooled } \\
\text { (SE) }\end{array}$ \\
\hline Constant & $1.7766^{* * *}$ & $(0.406)$ & $3.1493^{* * *}$ & $(0.959)$ & $1.9273^{* * *}$ & $(0.387)$ \\
\hline USE & $0.519^{* * *}$ & $(0.176)$ & -0.1691 & $(0.309)$ & $0.3906^{* *}$ & $(0.16)$ \\
\hline GENPROB & -0.071 & $(0.216)$ & $-0.727^{*}$ & $(0.443)$ & -0.2054 & $(0.195)$ \\
\hline DIRTSED & -0.204 & $(0.191)$ & $0.7128^{* *}$ & $(0.343)$ & -0.051 & $(0.172)$ \\
\hline CONCERN & $0.3346^{* *}$ & $(0.152)$ & 0.1683 & $(0.297)$ & $0.3404^{* *}$ & $(0.141)$ \\
\hline TMDL & -0.0967 & $(0.332)$ & $1.427^{* *}$ & $(0.57)$ & 0.1439 & $(0.294)$ \\
\hline TMDLEDU & 0.547 & $(0.451)$ & -0.8548 & $(0.715)$ & 0.3154 & $(0.382)$ \\
\hline FISH & 0.1213 & $(0.184)$ & -0.0182 & $(0.465)$ & 0.2096 & $(0.172)$ \\
\hline QUALITY & -1.094 & $(0.696)$ & 0.5683 & $(0.836)$ & -0.277 & $(0.538)$ \\
\hline FISHSTOC & -0.0587 & $(0.163)$ & 0.2355 & $(0.33)$ & 0.02 & $(0.149)$ \\
\hline DISTRUST & 0.2494 & $(0.155)$ & -0.0803 & $(0.286)$ & 0.2047 & $(0.138)$ \\
\hline GENDER & -0.0384 & $(0.161)$ & -0.5295 & $(0.332)$ & -0.0923 & $(0.148)$ \\
\hline$A G E$ & $0.0152^{* * *}$ & $(0.006)$ & 0.0134 & $(0.011)$ & $0.0154^{* * *}$ & $(0.005)$ \\
\hline$E D U$ & $0.3695^{* *}$ & $(0.168)$ & $0.9005^{* *}$ & $(0.376)$ & $0.4183^{* * *}$ & $(0.16)$ \\
\hline LAND & -0.0618 & $(0.222)$ & -0.0822 & $(0.436)$ & -0.1383 & $(0.199)$ \\
\hline LIFE & $0.3425^{*}$ & $(0.202)$ & $-1.0862^{* *}$ & $(0.431)$ & 0.1632 & $(0.186)$ \\
\hline INCOME & $0.0087^{* * *}$ & $(0.001)$ & 0.0014 & $(0.004)$ & $0.0082^{* * *}$ & $(0.001)$ \\
\hline Sigma & $0.8172^{* * *}$ & $(0.054)$ & $0.6476^{* * *}$ & $(0.08)$ & $0.848^{* * *}$ & $(0.049)$ \\
\hline $\begin{array}{l}\text { Log- } \\
\text { likelihood }\end{array}$ & \multicolumn{2}{|c|}{-317.18} & \multicolumn{2}{|c|}{-77.26} & \multicolumn{2}{|c|}{-409.03} \\
\hline
\end{tabular}

${ }^{a}$ Note: ${ }^{*}, * *,{ }^{* * *}$ denote statistical significance at $\mathrm{P}<0.10, \mathrm{P}<0.05, \mathrm{P}<0.01$, respectively.

When comparing the VAGP and VARL sub-samples for in-state WTP, log likelihood results were -409.04 for the pooled (VAGP + VARL), -317.18 for VAGP and 77.26 for VARL. A test statistic of 29.194 was calculated which is greater than the statistic following the $\chi^{2}$ distribution $\left(\chi^{2}{ }_{0.05,16}=26.296\right)$. Because of this, the null hypothesis cannot be accepted and the two populations cannot be pooled. LLR tests show that all three sub-samples are separate populations and should not be pooled when examining in-state WTP.

Comparing the VAGP and VARL sub-samples, different variable coefficients were found to be statistically significant in determining WTP for in-state water quality improvements. Variable coefficients USE, CONCERN and INCOME were found to be 
statistically significant in determining WTP for in-state improved water quality by the VAGP sub-sample but not by the VARL sub-sample. Variable coefficients GENPROB, DIRTSED and TMDL were found to be statistically significant in determining individuals WTP for in-state water quality improvements for the VARL sub-sample but not for the VAGP sub-sample.

Results of this LLR test, initial and final grouped tobit models were developed when examining in-state WTP for the VARL sub-sample. Table 4.11 summarizes results from the initial VARL grouped tobit model.

Table 4.11- Summary of Initial Grouped Tobit Model Results for WTP by VARL respondents for In-state Clean-up. ${ }^{19}(\mathrm{~N}=37)^{\mathrm{a}}$

\begin{tabular}{|l|cc|l|cc|}
\hline Variable & $\begin{array}{c}\text { Coefficient } \\
\text { estimate }\end{array}$ & $(\mathrm{SE})$ & Variable & $\begin{array}{c}\text { Coefficient } \\
\text { estimate }\end{array}$ & $(\mathrm{SE})$ \\
\hline Constant & $3.1727^{* * *}$ & $(0.961)$ & FISHSTOC & 0.2227 & $(0.332)$ \\
\hline FAMILUP & 0.0816 & $(0.262)$ & DISTRUST & -0.0635 & $(0.29)$ \\
\hline USE & -0.1592 & $(0.31)$ & GENDER & -0.511 & $(0.337)$ \\
\hline GENPROB & $-0.7491^{* *}$ & $(0.448)$ & AGE & 0.1274 & $(0.011)$ \\
\hline DIRTSED & $0.7348^{* *}$ & $(0.349)$ & EDU & $0.8774^{* *}$ & $(0.383)$ \\
\hline CONCERN & 0.1729 & $(0.297)$ & RIPLAND & -0.1083 & $(0.444)$ \\
\hline TMDL & $1.3933^{* *}$ & $(0.579)$ & LIFE & $-1.1048^{* *}$ & $(0.434)$ \\
\hline TMDLEDU & -0.804 & $(0.732)$ & INCOME & 0.0014 & $(0.004)$ \\
\hline FISH & -0.0283 & $(0.465)$ & Sigma & $0.6465^{* * *}$ & $(0.08)$ \\
\hline QUALITY & 0.5567 & $(0.835)$ & Log-likelihood & \multicolumn{2}{|c|}{-77.21} \\
\hline
\end{tabular}

Examining the initial VARL in-state grouped tobit model (Table 4.11), variables dropped included, FAMILUP, USE, CONCERN, TMDLEDU, FISH, QUALITY, FISHSTOC, DISTRUST, AGE, RIPLAND and INCOME. These variables were also dropped because of their lack of explanatory power. All of these variables had p-values greater than 0.5 . Dropping these variables produced a final grouped tobit model for the VARL sub-sample when examining in-state WTP (Table 4.12).

\footnotetext{
${ }^{19}$ VARL models for in-state and out-of-state clean-up did not exclude respondents who had stated that they were not riparian landowners (14 respondents).
} 
Table 4.12- Summary of Final Grouped Tobit Model Results for WTP by VARL respondents for In-state Clean-up. $(\mathrm{N}=37)^{\mathrm{a}}$

\begin{tabular}{|l|ll|l|lc|}
\hline Variable & $\begin{array}{l}\text { Coefficient } \\
\text { estimate }\end{array}$ & $(\mathrm{SE})$ & Variable & $\begin{array}{l}\text { Coefficient } \\
\text { estimate }\end{array}$ & $(\mathrm{SE})$ \\
\hline Constant & $3.984^{* * *}$ & $(0.346)$ & EDU & $0.7455^{* * *}$ & $(0.271)$ \\
\hline GENPROB & -0.5945 & $(0.393)$ & LIFE & $-1.242^{* * *}$ & $(0.408)$ \\
\hline DIRTSED & $0.7582^{* *}$ & $(0.327)$ & & & \\
\hline TMDL & $0.9039^{* * *}$ & $(0.317)$ & Sigma & $0.7092^{* * *}$ & $(0.088)$ \\
\hline GENDER & $-0.6458^{* * *}$ & $(0.247)$ & Log-likelihood & \multicolumn{2}{|c|}{-80.61} \\
\hline
\end{tabular}

${ }^{a}$ Note: ${ }^{*},{ }^{* *},{ }^{* * *}$ denote statistical significance at $\mathrm{P}<0.10, \mathrm{P}<0.05, \mathrm{P}<0.01$, respectively.

Virginia riparian landowners who are male, have at least a college education,

think there are dirt or sediment problems within the creeks and are aware of the TMDL

were found to have a higher WTP for improved water quality within the Virginia portion of the Opequon watershed.

Because LLR test results for both general public sub-samples found the two subsamples to have different coefficients in determining WTP for in-state clean-up, initial and final grouped tobit models were also developed for the WVGP sub-sample. Initial model results are summarized in Table 4.13.

Table 4.13- Summary of Initial Grouped Tobit Model Results for WTP by WVGP respondents for In-state Clean-up. $(\mathrm{N}=178)^{\mathrm{a}}$

\begin{tabular}{|c|c|c|c|c|c|}
\hline Variable & $\begin{array}{c}\text { Coefficient } \\
\text { estimate }\end{array}$ & (SE) & Variable & $\begin{array}{c}\text { Coefficient } \\
\text { estimate }\end{array}$ & (SE) \\
\hline Constant & $2.2489^{* * *}$ & $(0.36)$ & DISTRUST & 0.1056 & $(0.132)$ \\
\hline FAMILWV & -0.0317 & $(0.189)$ & GENDER & 0.2147 & $(0.154)$ \\
\hline USE & $0.5383^{* * *}$ & $(0.176)$ & $A G E$ & $0.0131^{* * *}$ & $(0.005)$ \\
\hline GENPROB & 0.1031 & $(0.194)$ & $E D U$ & 0.0485 & $(0.14)$ \\
\hline DIRTSED & 0.0836 & $(0.156)$ & LAND & -0.0435 & $(0.186)$ \\
\hline CONCERN & 0.1479 & $(0.14)$ & LIFE & $-0.5269^{* * *}$ & $(0.167)$ \\
\hline FISH & -0.1086 & $(0.16)$ & INCOME & $0.0064^{* * *}$ & $(0.002)$ \\
\hline QUALITY & -0.6756 & $(0.443)$ & Sigma & $0.8325^{* * *}$ & $(0.047)$ \\
\hline PUBACC & -0.1732 & $(0.144)$ & Log-likelihood & \multicolumn{2}{|c|}{-428.32} \\
\hline
\end{tabular}

When examining the initial WVGP in-state grouped tobit model (Table 4.13), variables were dropped. These variables include FAMILWV and GENPROB. Although 
$E D U$ and LAND had p-values greater than 0.7 , they were included in the final model because of results found in previous literature that show education and landownership being a significant determinant of one's WTP. Final in-state WTP grouped tobit model results for the WVGP sub-sample are summarized in Table 4.14.

Table 4.14- Summary of Final Grouped Tobit Model Results for WTP by WVGP respondents for In-state Clean-up. $(\mathrm{N}=178)^{\mathrm{a}}$

\begin{tabular}{|l|cc|l|cc|}
\hline Variable & $\begin{array}{c}\text { Coefficient } \\
\text { estimate }\end{array}$ & $(\mathrm{SE})$ & Variable & $\begin{array}{c}\text { Coefficient } \\
\text { estimate }\end{array}$ & $(\mathrm{SE})$ \\
\hline Constant & $2.2781^{* * * *}$ & $(0.354)$ & GENDER & 0.2196 & $(0.151)$ \\
\hline USE & $0.5646^{* * *}$ & $(0.167)$ & AGE & $0.1338^{* * *}$ & $(0.005)$ \\
\hline DIRTSED & 0.1178 & $(0.141)$ & EDU & 0.0466 & $(0.14)$ \\
\hline CONCERN & 0.1354 & $(0.138)$ & LAND & -0.0484 & $(0.184)$ \\
\hline FISH & -0.101 & $(0.16)$ & LIFE & $-0.514^{* * *}$ & $(0.166)$ \\
\hline QUALITY & $-0.7236^{* *}$ & $(0.435)$ & INCOME & $0.0064^{* * * *}$ & $(0.002)$ \\
\hline PUBACC & -0.1697 & $(0.144)$ & Sigma & $0.8331^{* * *}$ & $(0.002)$ \\
\hline DISTRUST & 0.1052 & $(0.132)$ & Log-likelihood & \multicolumn{2}{|c|}{-428.47} \\
\hline
\end{tabular}

${ }^{a}$ Note: ${ }^{*},{ }^{* *},{ }^{* * *}$ denote statistical significance at $\mathrm{P}<0.10, \mathrm{P}<0.05, \mathrm{P}<0.01$, respectively.

West Virginia residents who use the creeks for recreation, are older, have the opinion that the overall quality of their environment has not improved over the past few years, have not lived within the watershed their entire life and have higher incomes were found to have a higher WTP for water quality improvements within the West Virginia portion of Opequon watershed.

In Virginia, more statistically significant variables were found that influence WTP for in-state water quality improvements, compared to WVGP and VARL households. Variables USE, CONCERN, TMDLEDU, AGE, EDU, and INCOME were found to all positively influence an individual's WTP for in-state water quality improvements within Opequon watershed. Variables QUALITY, GENPROB and GENDER were found to negatively affect WTP for in-state water quality improvements. The LIFE variable indicting how long an individual has lived within the watershed, switched from being 
positive in the VAGP model to being negative in the WVGP and VARL models.

INCOME was found to be highly significant for both VAGP and WVGP models but was found to be insignificant for the VARL model.

Results were also obtained through grouped tobit models which explain WTP for water quality improvements for the adjacent state's water quality problems. These models were developed with WTP for out-of-state clean-up as the dependent variable. Compared to in-state WTP, a similar modeling process was done for out-of-state WTP. To determine if WVGP and VAGP sub-samples were similar enough to be combined into a pooled data set for out-of-state WTP, a third LLR test was conducted between these two sub-samples (Table 4.15).

Table 4.15- Summary of Grouped Tobit Model Results when comparing WTP for Outof-State Clean-up by VAGP and WVGP Sub-samples. ${ }^{\text {a }}$

\begin{tabular}{|l|cc|cc|cc|}
\hline Variable & $\begin{array}{c}\text { WVGP } \\
\text { coefficient } \\
\text { estimate }\end{array}$ & $\begin{array}{c}\text { WVGP } \\
\text { (SE) }\end{array}$ & $\begin{array}{c}\text { VAGP } \\
\text { coefficient } \\
\text { estimate }\end{array}$ & $\begin{array}{c}\text { VAGP } \\
\text { (SE) }\end{array}$ & $\begin{array}{c}\text { Pooled } \\
\text { coefficient } \\
\text { estimate }\end{array}$ & $\begin{array}{c}\text { Pooled } \\
\text { (SE) }\end{array}$ \\
\hline Constant & $1.771^{* * *}$ & 0.403 & $1.937^{* * *}$ & 0.439 & $1.97^{* * *}$ & 0.303 \\
\hline FAMIL & 0.131 & 0.21 & $0.604^{* *}$ & 0.288 & $0.314^{*}$ & 0.172 \\
\hline USE & 0.0839 & 0.203 & 0.239 & 0.202 & 0.119 & 0.144 \\
\hline GENPROB & 0.232 & 0.22 & 0.009 & 0.283 & 0.16 & 0.167 \\
\hline DIRTSED & -0.098 & 0.168 & 0.003 & 0.241 & -0.085 & 0.136 \\
\hline CONCERN & 0.244 & 0.153 & 0.162 & 0.176 & $0.216^{*}$ & 0.116 \\
\hline FISH & 0.247 & 0.183 & 0.011 & 0.2 & 0.136 & 0.134 \\
\hline QUALITY & 0.084 & 0.472 & -0.451 & 0.525 & -.123 & 0.359 \\
\hline VOTE & $0.5^{* * *}$ & 0.183 & 0.22 & 0.24 & $0.428^{* * *}$ & 0.147 \\
\hline PUBACC & $-0.373^{* *}$ & 0.159 & 0.141 & 0.183 & -0.143 & 0.121 \\
\hline DISTRUST & 0.1 & 0.143 & 0.144 & 0.174 & 0.149 & 0.111 \\
\hline GENDER & 0.14 & 0.171 & -0.022 & 0.18 & 0.003 & 0.123 \\
\hline AGE & $0.011^{* * *}$ & 0.005 & $0.02^{* * *}$ & 0.007 & $0.011^{* * *}$ & 0.004 \\
\hline EDU & 0.02 & 0.159 & 0.096 & 0.181 & 0.03 & 0.118 \\
\hline LAND & 0.255 & 0.198 & $-0.504^{* *}$ & 0.254 & -0.284 & 0.156 \\
\hline LIFE & $-0.456^{* *}$ & 0.178 & 0.161 & 0.244 & $-0.271^{* *}$ & 0.145 \\
\hline INCOME & $0.007^{* * *}$ & 0.002 & $0.005^{* * * *}$ & 0.002 & $0.006^{* * *}$ & 0.001 \\
\hline Sigma & $0.884^{* * *}$ & 0.052 & $0.859^{* * *}$ & 0.061 & $0.907^{* * *}$ & 0.041 \\
\hline $\begin{array}{l}\text { Log- } \\
\text { likelihood }\end{array}$ & \multicolumn{2}{|c|}{-412.38} & \multicolumn{2}{|c|}{-288.69} & & -711.42 \\
\hline a Note: ${ }^{*}{ }^{* *},{ }^{* * * *}$ denote statistical significance at $\mathrm{P}<0.10, \mathrm{P}<0.05, \mathrm{P}<0.01$, respectively. & \\
\hline
\end{tabular}


When comparing the VAGP and WVGP sub-samples for out-of-state WTP, log likelihood results were -711.42 for the pooled (VAGP + WVGP), -288.69 for VAGP and -412.38 for WVGP. A test statistic of 20.7 was calculated which is less than the statistic following the $\chi^{2}$ distribution $\left(\chi_{0.05,16}^{2}=26.296\right)$. Because of this, the null hypothesis cannot be rejected and the two populations can be pooled. This LLR test shows that WVGP and VAGP sub-samples are from the same population when examining out-ofstate WTP.

From this LLR test when examining out-of-state WTP, a final grouped tobit model was developed (Table 4.16). In the initial grouped tobit model for the pooled general public sub-samples, variables DIRTSED, QUALITY, GENDER, EDU and LAND were found to have $\mathrm{p}$-values greater than 0.5 , indicating little explanatory power. Because of this, these variables were not included in the final model.

Table 4.16- Summary of Final Grouped Tobit Model Results for WTP by Pooled General Public Respondents for Out-of-state Clean-up. $(\mathrm{N}=289)^{\mathrm{a}}$

\begin{tabular}{|l|cc|l|cc|}
\hline Variable & $\begin{array}{c}\text { Coefficient } \\
\text { estimate }\end{array}$ & $(\mathrm{SE})$ & Variable & $\begin{array}{c}\text { Coefficient } \\
\text { estimate }\end{array}$ & (SE) \\
\hline Constant & $1.972^{* * *}$ & 0.264 & PUBACC & -0.157 & 0.12 \\
\hline FAMIL & $0.312^{*}$ & 0.171 & DISTRUST & 0.155 & 0.111 \\
\hline USE & 0.117 & 0.143 & AGE & $0.011^{* * *}$ & 0.004 \\
\hline GENPROB & 0.121 & 0.145 & LIFE & $-0.277^{* *}$ & 0.142 \\
\hline CONCERN & $0.211^{*}$ & 0.115 & INCOME & $0.006^{* * *}$ & 0.001 \\
\hline FISH & 0.143 & 0.129 & Sigma & $0.908^{* * *}$ & 0.041 \\
\hline VOTE & $0.429^{* * *}$ & 0.146 & Log-likelihood & -711.738 & \\
\hline
\end{tabular}

${ }^{a}$ Note: $*,{ }^{*},{ }^{* * *}$ denote statistical significance at $\mathrm{P}<0.10, \mathrm{P}<0.05, \mathrm{P}<0.01$, respectively.

When examining WTP for out-of-state of state clean-up, all general public watershed residents who were older, had not lived within the watershed their entire life and had higher incomes were found to have a higher WTP for improved water quality within the opposite's states' portion of the watershed. In addition, all general public 
watershed residents who were familiar with the opposite's states' portion of the watershed, were very concerned about aquatic life and supported in-state water quality improvements, were also found to have a higher WTP for improved water quality within the opposite's states' portion of the watershed.

Initial grouped tobit models were developed for the VARL sub-sample when examining WTP for out-of-state clean-up but were found to be meaningless due to lack of variation by explanatory variables. For this sub-sample and clean-up plan, there were too few observations to justify use of the grouped tobit model. Instead, survey median values will be used to project WTP to the entire sample population for this sub-sample and clean-up plan.

Before WTP values could be estimated, protest responses were examined. For the VAGP sub-sample, 69 zero WTP respondents were recorded. For the WVGP sub-sample, 117 zero WTP respondents were recorded and for the VARL sub-sample 21 zero WTP respondents were recorded. For the VAGP sub-sample, 28 respondents were found to be in protest, while for the WVGP sub-sample, 49 respondents were determined protesters. This equates to approximately $41 \%$ of VAGP non-supporters and $42 \%$ of WVGP nonsupporters. Excluding protesters, 41 respondents in Virginia and 68 respondents in West Virginia were found to have true zero WTP for improved water quality in Opequon watershed. Examining the VARL sub-sample, approximately $43 \%$ (nine respondents) of non-supporters were found to be protesters. A total of 12 respondents were found to have a true zero WTP.

Once final WTP models were developed for in-state and out-of-state water quality improvements, and protest response were excluded, welfare estimates were calculated for 
respondents (Table 4.17). These welfare measurements represent a household WTP for improved water quality. WTP values were estimated using the coefficient results from the grouped tobit final model as well as including those respondents who stated a non-protest zero WTP. Coefficient estimates from final grouped tobit models were multiplied by each observation to estimate respondent WTP values. WTP values greater than or equal to zero were calculated by including non-protest zero WTP respondents in the analysis. Median WTP values, greater than or equal to zero were used in part to project WTP values to the population.

Table 4.17- Summary of Respondent Mean and Median WTP by Sub-Sample.

\begin{tabular}{|l|c|c|c|c|}
\hline \multirow{2}{*}{} & \multicolumn{4}{|c|}{ In-state WTP } \\
\cline { 2 - 5 } & Mean & Mean & Median & Median \\
\hline & WTP $>0$ & WTP $\geq 0$ & WTP $>0$ & WTP $\geq 0$ \\
\hline WVGP (N=178) & $\$ 61.90$ & $\$ 44.84$ & $\$ 43.80$ & $\$ 31.69$ \\
\hline VAGP (N=131) & $\$ 89.45$ & $\$ 68.13$ & $\$ 63.55$ & $\$ 48.40$ \\
\hline VARL (N=37) & $\$ 105.46$ & $\$ 79.63$ & $\$ 82.01$ & $\$ 61.93$ \\
\hline & \multicolumn{4}{|c|}{ Out-of-state WTP } \\
\cline { 2 - 5 } & Mean & Mean & Median & Median \\
\hline & WTP $>0$ & WTP $\geq 0$ & WTP $>0$ & WTP $\geq 0$ \\
\hline $\begin{array}{l}\text { Pooled General } \\
\text { Public }(\mathrm{N}=289)\end{array}$ & $\$ 40.39$ & $\$ 27.06$ & $\$ 26.75$ & $\$ 17.92$ \\
\hline VARL $(\mathrm{N}=30)^{20}$ & $\$ 62.23$ & $\$ 34.57$ & $\$ 50.00$ & $\$ 7.50$ \\
\hline
\end{tabular}

When examining estimated respondent WTP, the VARL sub-sample was found to have the highest WTP for in-state water quality improvements. One reason for this may be because these respondents have a greater stake in the outcome of their portion of the watershed improvement plan. An additional reason may be because of their close proximity to the creeks. Also, one could argue that VARL households are most affected by improved water quality and would have a higher WTP because this. Comparing WTP for in-state clean-up by the general public sub-samples, VAGP respondents were found to

\footnotetext{
${ }^{20}$ WTP for out-of-state clean-up by the VARL sub-sample was estimated by survey mean and median values instead of model coefficients.
} 
have a higher WTP than WVGP respondents. Because the WVGP and VAGP subsamples were found to represent the same population when using a LLR test, they have the same WTP for out-of-state clean-up. Both WVGP and VAGP respondents were found to have a higher WTP for out-of-state clean-up compared to VARL respondents.

Average mean and median WTP values were also estimated for non-respondents. This procedure was done in part to control for the possibility of survey non-response error. This was done by using respondent grouped tobit model coefficients, imputed values and 2000 Census demographic information (United States Census Bureau, 2000). This calculation was necessary for WVGP and VAGP sub-samples because of low survey response rates. Although the majority of households who received the survey instrument did not return a completed survey questionnaire, it could not be assumed that these households had a zero WTP value. A respondent's income was found to be a major determinant of WTP and would contribute to these residents having a positive WTP as well. In addition, individual time constraints, as well as the decision to only distribute the survey instrument one-time may have contributed to low response rates.

Table 4.18 describes non-respondent household WTP estimates. Grouped tobit model coefficients were used from an additional model which included only the variables that were found statistically significant in the final model. Variables USE, CONCERN, QUALITY, TMDLEDU and LIFE used sample mean values from the grouped tobit model as imputed values. Variables AGE, EDU, and INCOME used 2000 Census data weighted according to zip code sampling percentages as imputed values (United States Census Bureau, 2000). WTP values for those individuals that had a positive or non-protest zero WTP were calculated by multiplying positive non-respondent WTP values, by the CV 
question support rate. Because the grouped tobit model only includes those with a positive WTP, this calculation allows to account for non-respondents who had zero WTP.

Table 4.18- Summary of Non-Respondent Mean and Median WTP by Sub-Sample.

\begin{tabular}{|l|c|c|c|c|}
\hline \multirow{2}{*}{} & \multicolumn{4}{|c|}{ In-state WTP } \\
\cline { 2 - 5 } & Mean & Mean & Median & Median \\
\hline WVGP & WTP $>0$ & WTP $\geq 0$ & WTP $>0$ & WTP $\geq 0$ \\
\hline VAGP & $\$ 35.23$ & $\$ 24.31$ & $\$ 24.90$ & $\$ 17.18$ \\
\hline & $\$ 65.72$ & $\$ 47.32$ & $\$ 33.17$ & $\$ 23.88^{21}$ \\
\cline { 2 - 5 } & Mean & Mean & Median & Median \\
\hline & WTP $>0$ & WTP $\geq 0$ & WTP $>0$ & WTP $\geq 0$ \\
\hline WVGP & $\$ 25.08$ & $\$ 16.81$ & $\$ 16.66$ & $\$ 11.17$ \\
\hline VAGP & $\$ 18.63$ & $\$ 12.48$ & $\$ 12.99$ & $\$ 8.70$ \\
\hline
\end{tabular}

WVGP non-respondents were found to have a lower in-state WTP than VAGP non-respondents but were found to have a higher out-of-state WTP, compared to VAGP non-respondents. This is an identical relationship as respondents WTP. As described earlier, VAGP non-respondents may have an increased awareness of in-state water quality problems through the TMDL process resulting in higher WTP for in-state cleanup, compared to WVGP non-respondents. WVGP non-respondents may have a higher out-of-state WTP because Opequon Creek flows north, with most of the pollution also traveling this same direction. Assuming this is the case, pollution is more likely to originate in Virginia and travel to West Virginia. West Virginia residents have a higher WTP for Virginia clean-up because they may be concerned with improvement of the water before it enters their portion of the watershed. Following this, Virginia residents may have a lower WTP because less pollution travels from West Virginia to Virginia.

\footnotetext{
${ }^{21}$ As a check of non-respondent WTP estimates, a follow-up telephone survey contacted 21 random nonrespondent households in Virginia and asked an abbreviated version of the mail questionnaire. Results from the telephone survey found that these non-respondents had an average median WTP for in-state clean-up of $\$ 23.50$, compared to the mail survey non-respondent WTP of $\$ 23.88$.
} 
Lastly, in all cases non-respondent mean WTP estimates were found to be higher than non-respondent median WTP estimates because of the inclusion of $\sigma$ values.

\subsection{Total Economic Benefits of Improved Water Quality}

The total economic benefits of improved water quality within Opequon watershed are equal to the vertical sum of each household WTP (Bjornstad and Kahn, 1996; Samuelson, 1954). Census household watershed estimates were used to project WTP estimates from improved water quality within Opequon watershed over the entire watershed (Table 3.1). This includes 19,330 general public households in Virginia, 24,569 general public households in West Virginia and 392 Virginia riparian landowner households. With respect to this study, the total economic benefits reflect a measure of making Opequon and Abrams Creeks safe for swimming and wading in Virginia, and making Opequon Creek safe for swimming, wading and able to support year-round fish populations in West Virginia.

The aggregation process of a household WTP was completed using three scenarios as well as three discount rates. Discount rates for in-state WTP were varied to examine the sensitivity of one's WTP. The three scenario projections were created to address the issue of possible non-response error. All scenario projects were done using grouped tobit model median WTP values, which included those with a positive or nonprotest zero WTP. Figure 4.7 displays the total economic benefits of improving water

quality with Opequon watershed using High scenario assumptions, Figure 4.8 displays the total benefits using Medium scenario assumptions, and Figure 4.9 displays the total benefits using Low scenario assumptions. A table displaying numeric dollar estimates can be found in Appendix 4. 
The total economic benefits were found to be greatest under the High scenario (Figure 4.7). This is because of the assumption that the sample respondent WTP estimate was reflective of the population and could be aggregated to each of the households within the sub-sample and improvement plan. Total benefits over the entire watershed under the High scenario ranged between $\$ 6.3$ and $\$ 8.8$ million. WTP by WVGP residents ranged from $\$ 2.9$ to $\$ 4.0$ million, while WTP by VAGP residents ranged from $\$ 3.3$ to $\$ 4.6$ million. WTP by VARL households ranged between $\$ 81,000$ and $\$ 115,000$. The total measured benefits for clean-up of the West Virginia portion of the Opequon watershed were found to range between $\$ 2.8$ and $\$ 3.9$ million while the total measured benefits for clean-up of the Virginia portion of the Opequon watershed were found to range between $\$ 3.5$ and $\$ 4.8$ million.

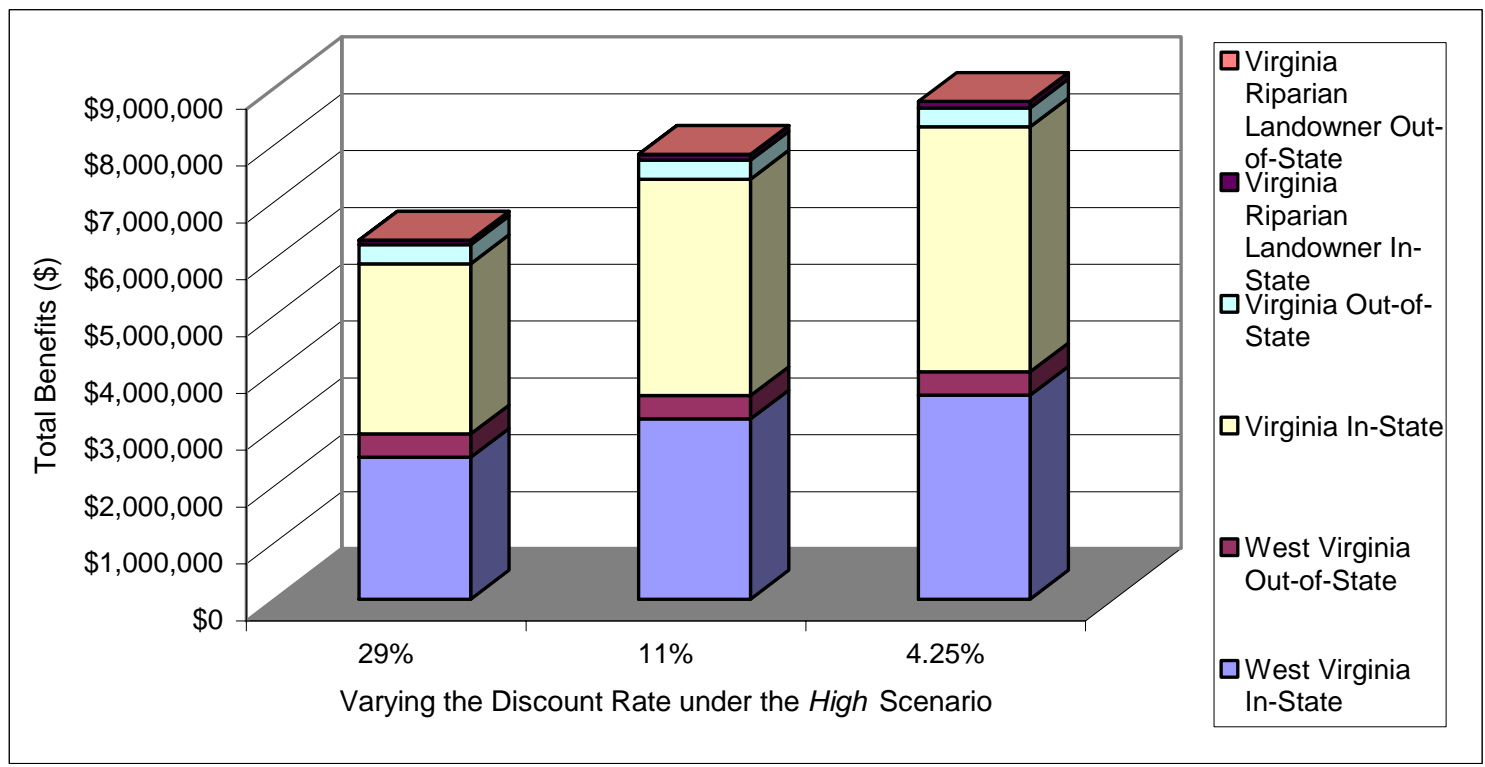

Figure 4.7- Total WTP for Water Quality Improvements in Opequon Watershed under the High Scenario.

Total benefit estimates for improving water quality within Opequon watershed were also estimated using the assumptions in the Medium scenario (Figure 4.8). In this scenario, the total benefits were found to be lower than in the High scenario but higher 
than the Low scenario (as expected). Total befits for this scenario over the entire watershed were found to range from $\$ 3.7$ to $\$ 5.1$ million. WTP by WVGP residents ranged from $\$ 1.8$ to $\$ 2.5$ million, while WTP by VAGP residents ranged from $\$ 1.8$ to $\$ 2.5$ million. WTP by VARL households ranged between $\$ 81,000$ and $\$ 115,000$. Total measured benefits for clean-up of the West Virginia portion of the Opequon watershed were found to range between $\$ 1.7$ and $\$ 2.4$ million while the total measured benefits for clean-up of the Virginia portion of the Opequon watershed were found to range between $\$ 2.0$ and \$2.7 million. Through statistical procedures to control for non-response error, this scenario produced the best total benefit estimates.

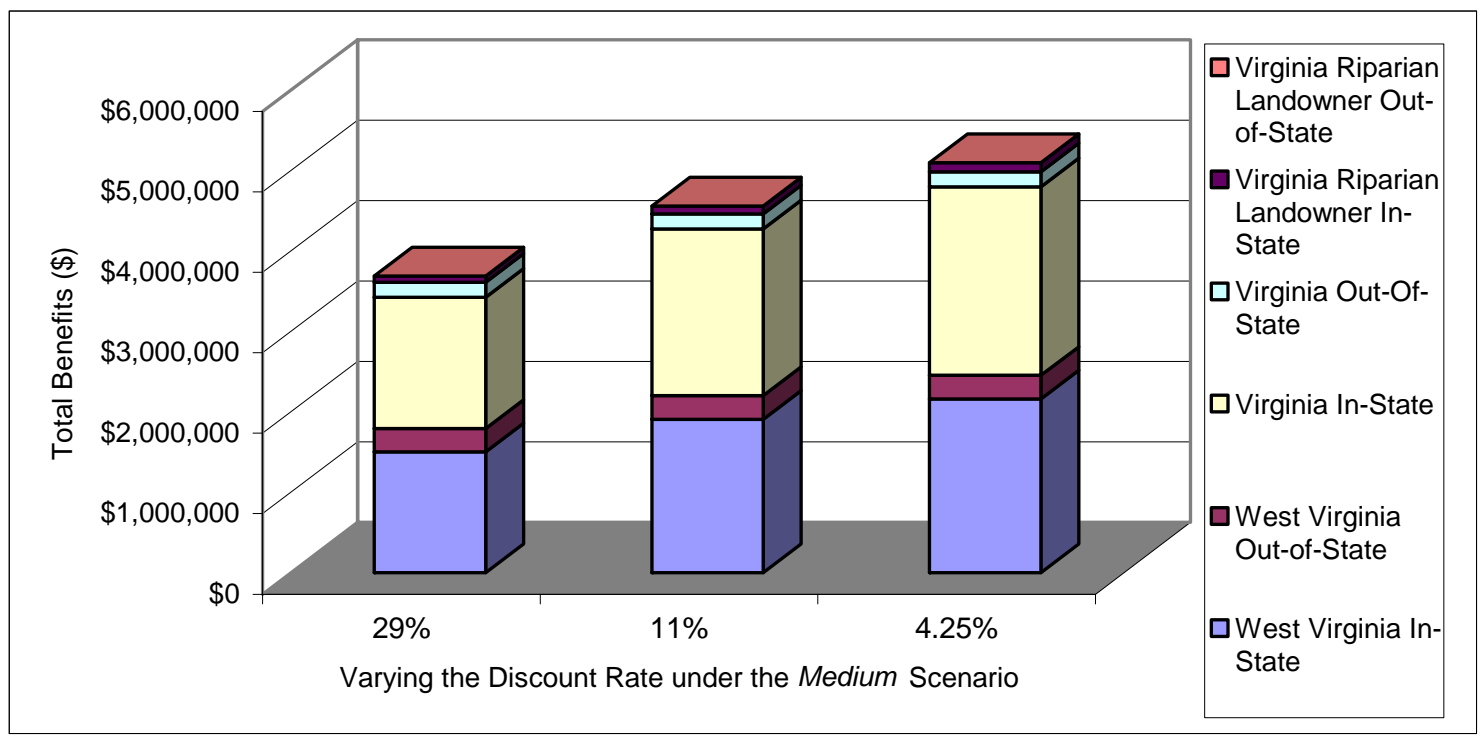

Figure 4.8- Total WTP for Water Quality Improvements in Opequon Watershed under the Medium Scenario.

In addition to the High and Medium scenarios, total benefit estimates for improving water quality within Opequon watershed were estimated using the assumptions in the Low scenario (Figure 4.9). Total benefit estimates in this scenario were found to be lowest of all three scenarios. Under this scenario, the total benefits for the entire watershed were found to range from approximately $\$ 790,000$ to $\$ 1.1$ million. 
WTP by WVGP residents ranged from $\$ 378,000$ to $\$ 520,000$, while WTP by VAGP residents ranged from $\$ 333,000$ to $\$ 464,000$. WTP by VARL households ranged between $\$ 81,000$ and $\$ 115,000$. The total measured benefits for clean-up of the West Virginia portion of the Opequon watershed were found to range between $\$ 0.4$ and $\$ 0.5$ million while the total measured benefits for clean-up of the Virginia portion of the Opequon watershed were found to range between $\$ 0.4$ and $\$ 0.6$. The major reason for such low benefit estimation in this scenario is because it was assumed that the percentage of the population that did not return a survey had a zero WTP for improved water quality. In this scenario, one can observe that VARL households contribute to a larger percentage of the clean-up, compared to the High and Medium scenarios.

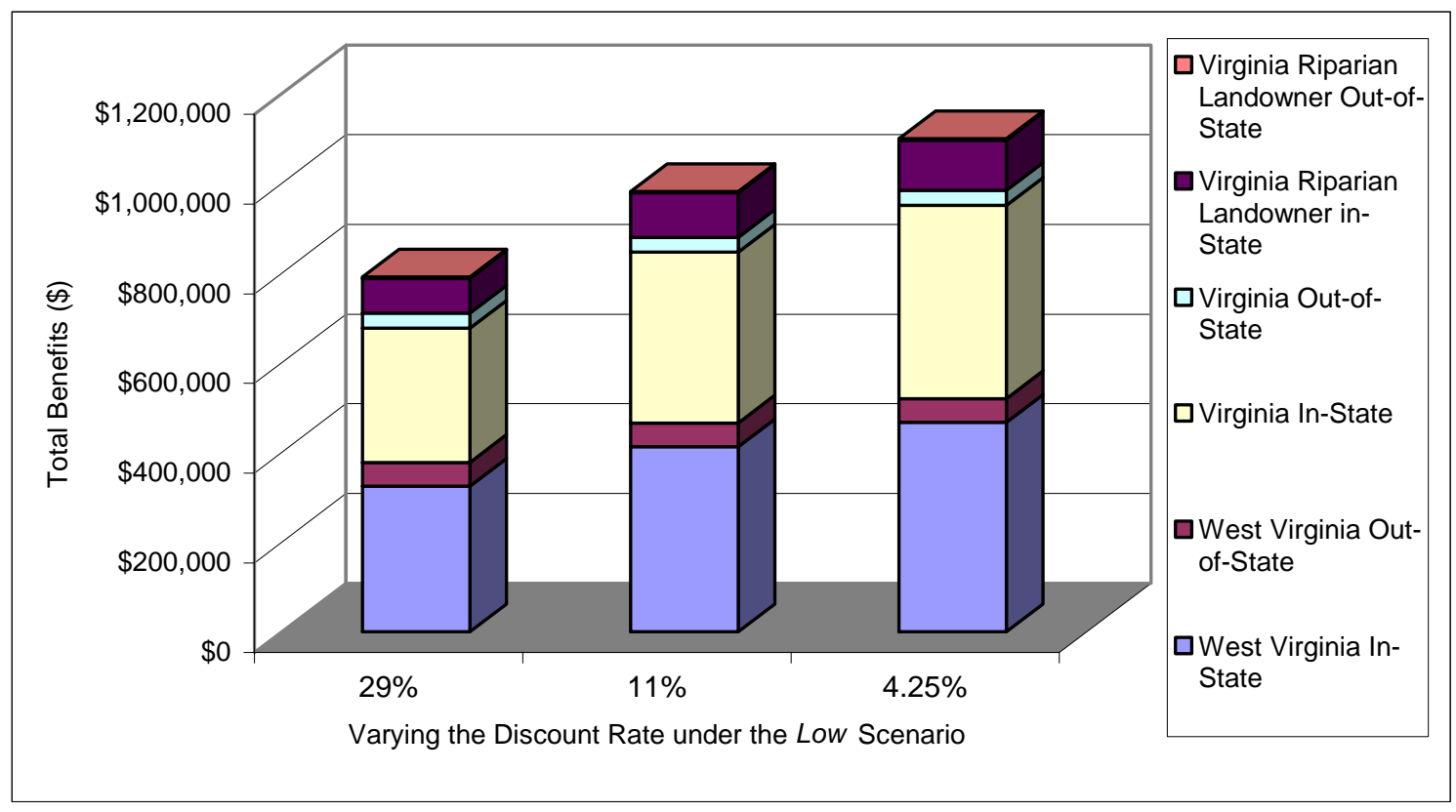

Figure 4.9- Total WTP for Water Quality Improvements in Opequon Watershed under the Low Scenario. 


\subsection{Discussion and Conclusions}

The importance of this study can be observed in various comments provided by respondents at the end of the survey. These comments included: "Please take the bull by the horns and do something"; "Please save our creek" and "I appreciate this opportunity and look forward to the results in action". Such comments indicate this study as being important not only to meet the requirements of the Total Maximum Daily Load (TMDL) Implementation Plan (IP), but also to local residents of this watershed.

When comparing Virginia and West Virginia general public sub-samples on the basis of $\log$ likelihood tests, each sub-sample, was found to represent a different population when examining an individual WTP for in-state water quality improvements in Opequon watershed. This result could be because of differences in water quality problems within each state, differences in socio-economic characteristics, as well as recreational use differences and the differences in the development of Virginia and West Virginia TMDLs. The differences between the sub-samples WTP for in-state improved water quality show that each respondent's portion of the watershed is viewed differently by each sub-sample. However, when comparing sub-samples on the basis of log likelihood tests when examining out-of-state WTP for water quality improvements, both West Virginia and Virginia general public sub-samples were found to have the same characteristics that influence one's WTP.

Table 5.1 describes the variables and their sign which were found to be statistically significant in determining a respondent WTP for improved water quality within Opequon Creek watershed. When examining in-state WTP, more variables were found to be statistically significant for Virginia respondents compared to West Virginia 
respondents. Overall, a respondent's age and income were found to have a positive affect in every general public WTP model. Use of the creeks was found to have a positive affect on WTP for both in-state models, while one's opinion about the quality of the environment was found to have a negative affect on WTP for both in-state models.

Table 5.1- Summary of Variables found to be Statistically Significant in determining WTP for General Public Households.

\begin{tabular}{|l|c|c|c|}
\hline \multirow{2}{*}{\multicolumn{1}{|c|}{ Variable }} & \multicolumn{3}{c|}{ Sub-sample } \\
\cline { 2 - 4 } & \multicolumn{2}{|c|}{ In-State WTP } & Out-of-State \\
\cline { 2 - 4 } & Virginia & West Virginia & Pooled \\
\hline $\begin{array}{l}\text { Familiar with the opposite states' portion } \\
\text { of Opequon Creek }\end{array}$ & 22 & \multicolumn{2}{|c|}{ Sign } \\
\hline $\begin{array}{l}\text { Use Opequon Creek or Abrams Creeks for } \\
\text { recreational activities }\end{array}$ & $(+)$ & $(+)$ & \\
\hline $\begin{array}{l}\text { Very concerned about the ability of fish } \\
\text { and other aquatic life to survive in } \\
\text { Opequon or Abrams Creeks }\end{array}$ & $(+)$ & & $(+)$ \\
\hline $\begin{array}{l}\text { At least a college degree and aware of the } \\
\text { TMDL }\end{array}$ & $(+)$ & & \\
\hline Regularly fish in a lake, river or creek & & & \\
\hline $\begin{array}{l}\text { Opinion that the overall quality of the } \\
\text { environment had improved in the past few } \\
\text { years }\end{array}$ & $(-)$ & $(-)$ & \\
\hline $\begin{array}{l}\text { Positive WTP for in-state water quality } \\
\text { improvements }\end{array}$ & & & $(+)$ \\
\hline $\begin{array}{l}\text { Wanted public access as an improvement } \\
\text { along side Opequon or Abrams Creeks }\end{array}$ & & & \\
\hline Age & $(+)$ & $(+)$ & $(+)$ \\
\hline At least a college degree & $(+)$ & & $(-)$ \\
\hline $\begin{array}{l}\text { Owned home or residential land within } \\
\text { Opequon watershed }\end{array}$ & & & $(+)$ \\
\hline $\begin{array}{l}\text { Lived within Opequon watershed their } \\
\text { entire life }\end{array}$ & $(+)$ & $(-)$ & $(+)$ \\
\hline Annual household income & $(+)$ & & \\
\hline
\end{tabular}

In Virginia, $72 \%$ of respondents were found to have a positive WTP for in-state water quality improvements. In West Virginia, $69 \%$ of respondents were found to have a

\footnotetext{
${ }^{22}$ Blank spaces mean that this variable was either not included in the respective model or was found to be statistically insignificant.
} 
positive WTP for in-state water quality improvements. From the sampled households, Virginia households were found to have a median WTP of \$48 annually for five years for in-state water quality improvements and $\$ 18$ in a one-time donation for out-of-state clean-up improvements. In addition, West Virginia sampled households were found to have a median WTP of \$32 annually for five years for in-state improvements and \$18 in a one-time donation for out-of-state improvements. Virginia riparian landowner sampled households were found to have a median WTP of $\$ 62$ annually for five years for in-state improvements and \$8 in a one-time donation for out-of-state improvements.

Using household WTP values by projecting them to the watershed population under Medium scenario assumptions, the total measured economic benefits within the entire Opequon watershed were estimated to range from $\$ 3.7$ to $\$ 5.1$ million. These estimates can be considered the most reliable total benefit estimates because of the statistical procedures completed, as well as the underlying assumptions of the Medium scenario. In order to control for the low response rate in the Medium scenario, respondents were assumed to be different than non-respondents although nonrespondents were still thought to have a positive WTP. Because of this, both respondent and non-respondent annual WTP were estimated separately by using the grouped tobit model. Using these models allowed for prediction of WTP across all households within the watershed. This type of statistical procedure seemed to be the best way to aggregate WTP values for the entire watershed. However, Low and High scenarios were also examined and the total measured benefits for the entire watershed were found to range from approximately $\$ 1.1$ to $\$ 8.8$ million. 
By using a contingent valuation (CV) survey to estimate the benefits of water quality improvements, direct information was transferred to the public via the Benefits Section of the TMDL IP. Information obtained from the survey was reported at watershed area stakeholder meetings to individuals involved in the TMDL implementation process, individuals involved with improving water quality in the West Virginia portion, as well as to local area residents. This survey also provided a vehicle for greater public participation and an increased awareness of water quality issues within Opequon Creek watershed. For every sub-sample, trash was cited as the number-one problem that respondents were aware of in the watershed. In addition, trash clean-ups were the number-one environmental improvement respondents asked for along the creeks. Although trash was not apart of the TMDL or IP, it can still be viewed as an important environmental issue to residents of Opequon Creek watershed.

Despite variance among survey instruments, household and aggregate WTP estimates can still be compared among similar, previous CV studies. ${ }^{23}$ Examining the range of annual household WTP estimates detailed in Table 2.1, annual WTP estimates for water quality improvements ranged between $\$ 60$ and $\$ 406$ in 2006 dollars. Comparing these WTP values with this studies median household WTP, estimates in this study are considerably lower. This result may stem from a conservative design as well as a conservative set of assumptions. In addition to this, total benefit estimates of improved water quality within the entire Opequon watershed were also found to be low compared to similar previous CV studies.

\footnotetext{
${ }^{23}$ Previous, similar CV studies include: Brox, Kumar and Stollery (2003); Collins, Rosenberger and Fletcher (2005); Eisen-Hecht and Kramer (2002); Loomis et al. (2000); Stumborg, Baerenklau, and Bishop (2001).
} 
To ensure that results are valid, content and construct validity were examined. Content validity was ensured by taking the necessary precautions before survey distribution which allowed for the instrument to accurately estimate the benefits of improved water quality within Opequon watershed. In addition, the CV question was phrased as a WTP question as suggested by Freeman (2003). Construct validity was ensured by comparing the findings of previous studies (e.g. determinants of WTP) with the determinants of WTP found in this study. Stumborg, Baerenklau, and Bishop (2001) state that regression results can be used to compare the data set with intuition and economic theory as informal tests of construct validity. Household income was found to have a positive and highly significant relationship in determining WTP for each general public grouped tobit model. This finding agrees with the theoretical construct, that as one's income increases, so does their WTP for a public good (Freeman, 2003). The vast majority of previous $\mathrm{CV}$ studies which estimate the benefits of a public good also found income to have a positive, statistically significant, effect on WTP (Brox, Kumar and Stollery, 2003; Collins, Rosenberger and Fletcher, 2005; Dalton et al., 1998; Danielson et al., 1995; Eisen-Hecht and Kramer, 2002; Hurley, Otto and Holtkamp, 1999; MacDonald, Bergstrom and Houston, 1998; Poe, 1998; Rosenberger, Collins and Svetlik, 2005; Stumborg, Baerenklau and Bishop, 2001; Whitehead, 2000).

An additional check of validity can be done by comparing a respondent's reported income and WTP. Compared to results found by Stumborg, Baerenklau and Bishop (2001), similar, yet better results were found in this study. When comparing respondents WTP for improved water quality within their portion of the watershed, no general public respondent reported a WTP greater than 1\% of their annual income. In addition to this, 
only 11 respondents, out of 367 general public responses, reported a WTP between $0.51 \%$ and $1 \%$ of their annual income. From this, one can conclude that respondents considered their budget constraints and substitution possibilities seriously when estimating their WTP for improved water quality within their portion of Opequon watershed (Stumborg, Baerenklau and Bishop, 2001).

Along with income, numerous previous CV studies found that a respondent's education level had a positive and significant relationship in determining WTP (Brox, Kumar and Stollery, 2003; Collins, Rosenberger and Fletcher, 2005; Danielson et al., 1995; Eisen-Hecht and Kramer, 2002; Hurley, Otto and Holtkamp, 1999; Rosenberger, Collins and Svetlik, 2005; Stumborg, Baerenklau and Bishop, 2001; Whitehead, 2000). When examining the Virginia riparian landowner grouped tobit model for in-state WTP, although household income was found to be statistically insignificant, a respondent's education was found to be positive and significantly related to a respondent WTP. This result helps validate model estimates from this sub-sample and improvement plan.

Lastly, a respondent's age was found to have a positive and significant relationship for all general public grouped tobit models in determining one's WTP for improved water quality within Opequon watershed. Similar results regarding age were found in previous CV studies as well (Brox, Kumar and Stollery, 2003; Collins, Rosenberger and Fletcher, 2005; Stumborg, Baerenklau and Bishop, 2001; Whitehead, 2000). Comparing the determinants of WTP in this study with the determinants of WTP found in other studies allows for these CV results to have construct validity. 


\subsection{Limitations and Future Research}

A limitation of this study comes from achieving lower than expected survey response rates. The overall survey response rate was $13 \%$. Because of this fairly low response rate, a possibility exists for point WTP estimators to be biased from nonresponse error. This bias would also affect total WTP estimates. Obtaining a higher response rate, could have provided a better representation of the watershed population. Although responses rates were fairly low, the survey distribution method contributed to this result. Studies referenced in Table 2.1 obtained responses rates between $26 \%$ and $70 \%$. With additional survey mailings, responses rates in this survey would have likely fallen closer to this range.

An added limitation stems the uncertainty of whether or not the water quality improvements described in the CV questions will be obtained through the drafted IP. Currently, the IP is being reviewed by stakeholders as well as local residents. The overall project period has been extended through May of 2006. Because of this, the IP has yet to be integrated to improve water quality standards within Opequon watershed. The extension of the IP means that the actual outcomes from water quality improvements will not be known for sometime.

Future research could focus on several issues which were not addressed in this study. In this study, only benefits to households within Opequon watershed were examined. However, households outside of the watershed could also experience benefits from the improved water quality within Opequon watershed. In addition, measured benefits included only those that made creeks in Opequon watershed safe for swimming and wadding as well as allowing for viable year-round fish populations in West Virginia. 
Added benefits from improved water quality were not measured such as increased property values. Future research could be completed by obtaining WTP information from households within close proximity to Opequon watershed and obtaining values for the additional benefits of improved water quality. Solicitation of one's WTP is not identical as collection of actually revenue. Because of this, additional research could also focus on achieving the best method by which revenues could be collected for improved water quality within Opequon watershed. 


\section{References}

Amemiya, T. “Tobit Models: A Survey.” Journal of Econometrics 24(1984):3-61.

Armstrong, J.S. and T. Overton. "Estimating Nonresponse Bias in Mail Surveys." Journal of Marketing Research 14(1977):396-402.

Arrow, K., R. Solow, P.R. Portney, E.E. Leamer, R. Radner, H. Schuman. "Report of the NOAA Panel on Contingent Valuation.” Federal Register (Jan.1993):4601-4614.

Barham, B., R. Zeckoski and B. Benham. TMDL Resource Directory. Mid-Atlantic CSREES Regional Water Quality Project, April 2004.

Benham, B.L., J. L. Walker, G. Yagow. "TMDLs (Total Maximum Daily Loads) for Benthic Impairments.” Virginia Cooperative Extension Publication 442-556, 2003.

Benham, B.L. and S. C. Zeckoski. "TMDLs (Total Maximum Daily Loads) for Bacteria Impairments." Virginia Cooperative Extension Publication 442-555, 2005.

Bergstrom, J.C., K.J. Boyle and G.L. Poe. The Economic Value of Water Quality. Northampton, MA: Edward Elgar Publishing Inc., 2001.

Bjornstad, D.J. and J.R. Kahn. The Contingent Valuation of Environmental Resources. Oak Ridge National Laboratory: Edward Elgar Publishing, Inc., 1996.

Blamey, R.K., J.W. Bennett and M.D. Morrison. "Yea-Saying in Contingent Valuation Surveys." Land Economics 75, 1(February 1999):126-141.

Bloomberg.com. "Bloomberg.com: Rates and Bonds," Online website available at: http://www.bloomberg.com/markets/rates/

Boyle, K. J., F. R. Johnson, D. W. McCollum, W. H. Desvousges, R. W. Dunford, and S. P Hudson. "Valuing Public Goods: Discrete versus Continuous Contingent Valuation Responses." Department of Resource Economics, Working Paper, University of Maine, 1993.

Brox, J.A., R.C. Kumar, K.R. Stollery. "Estimating Willingness to Pay for Improved Water Quality in the Presence of Item Nonresponse Bias." American Journal of Agricultural Economics 85, 2(May 2003):414-428.

Cameron, T., W. Shaw, and S. Ragland. Nonresponse Bias in Mail Survey Data: Salience Vs Endogenous Survey Complexity.” In J.A. Herriges and C.L Kling, ed. Valuing the Environment using Recreational Demand Models. Edward Elgar Publisher, 1999. 
Cameron, T.A. and D.D. Huppert. OLS versus ML estimation of Non-market Resource Values with Payment Card Interval Data. Journal of Environmental Economics and Management 17, 3(1989):230-246.

Carson, R.T. “Contingent Valuation: A User's Guide.” Environmental Science \& Technology, 34, 8(2000):1413 -1418.

Carson, R.T., N.E. Flores, K.M. Martin, and J.L. Wright. "Contingent Valuation and Revealed Preference Methodologies: Comparing the Estimates for Quasi-Public Goods." Land Economics 72, 1(1996):80-99.

Carson, R.T., T. Groves and M.J. Machina. "Incentive and Informational Properties of Preferences Questions," Paper presented at conference on the Theory and Application of Environmental Valuation, Japan Forum of Environmental Valuation, Kobe Japan, January 2000.

Carson, R.T., W.M. Hanemann, R.J. Kopp, J.A. Krosnick, R.C. Mitchell, S. Presser, P.A. Ruud, V.K. Smith, M. Conaway and K. Martin. "Referendum Design and Contingent Valuation: The NOAA Panel's No-Vote Recommendation." Working paper 96-05, Resources for the Future, 1995.

Carson, R.T., W.M. Hanemann and R.C. Mitchell. "The Use of Simulated Political Markets to Value Public Goods." Discussion paper 87-7, Department of Economics, University of California, San Diego, March 1987.

Carson, R.T. and R.C. Mitchell. “The Value of Clean Water: The Public's Willingness to Pay for Boatable, Fishable, and Swimmable Quality Water." Water Resources Research 29, 7(July 1993):2445-2454.

Champ, P.A., R.C. Bishop, T.C. Brown, and D.W. McCollum. "Using Donation Mechanisms to Value Nonuse Benefits from Public Goods." Journal of Environmental Economics and Management 33, 2(1997):151-62.

Champ, P.A., K.J. Boyle and T.C. Brown. A Primer on Nonmarket Valuation. Dordrecht: Kluwer Academic Publishers, 2003.

Collins, A., R. Rosenberger and J. Fletcher. "The Economic Value of Stream Restoration." Water Resources Research 41(2005):1-9.

Commonwealth of Virginia: Department of Conservation and Recreation and Department of Environmental Quality. TMDL Implementation Plan Guidance Manual, July 2003.

Congressional Research Service, The Library of Congress. Natural Resources: Assessing Nonmarket Values through Contingent Valuation. Washington DC, June 1999. 
Cummings, R.G., G.W. Harrison, and E.E. Rutstrom. "Homegrown Values and Hypothetical Surveys: Is the Dichotomous Choice Approach IncentiveCompatible?" American Economic Review 85, 1(1995):260-66.

Dalton, R.S., C.T. Bastian, J.J. Jacobs and T.A. Wesche. "Estimating the Economic Value of Improved Trout Fishing on Wyoming Streams." Journal of Fisheries and Management 18(1998):786-797.

Danielson, L., T.J. Hoban, G. Van Houtven and J.C. Whitehead. "Measuring the Benefits of Local Public Goods: Environmental Quality in Gaston County, North Carolina." Applied Economics, 27(1995): 1253-1260.

Deaton, A. and J. Muellbauer. Economics and Consumer Behavior. New York: Cambridge University Press, 1980.

Diamond, P.A. and J.A. Hausman. "Contingent Valuation: Is Some Number Better than No Number?” Journal of Economic Perspectives 8, 4(Fall 1994):45-64.

Dillman, D.A. Mail and Internet Surveys: The Tailored Design Method, 2nd ed. New York: John Wiley \& Sons, Inc., 2000.

Dillman, D.A., J.L. Eltinge, R.M. Groves, R.J.A. Little. Survey Nonresponse in Design, Data Collection, and Analysis. New York: John Wiley and Sons, Inc., 2002.

Duffield, J.W. and D.A. Patterson. "Field Testing Existence Values: Comparison of Hypothetical and Cash Transaction Values." Paper presented at American Economic Association annual meeting, New Orleans LA, 1991.

Eisen-Hecht, J.I., and R.A. Kramer. "A Cost- Benefit Analysis of Water Quality Protection in the Catawba Basin." Journal of the American Water Resources Association 38, 2(April 2002):453- 465.

Frederick, S., G. Loewenstein and T. O’Donoghue. "Time Discounting and Time Preference: A Critical Review. Journal of Economic Literature, American Economic Association 40, 2(2002):351-401.

Freeman, A.M. III. The Measurement of Environmental and Resource Values. Washington, DC: Resources for the Future, 2003.

Gately, D. "Individual Discount Rates and the Purchase and Utilization of Energy-Using Durables: Comment." The Bell Journal of Economics 11, 1(1980):373-374.

Greene, W.H. LIMDEP- Version 8.0 and NLOGIT- Version 3.0. Econometric Software Inc., 2002.

Gujarati, D.N. Basic Econometrics, 4th ed. Boston: McGraw Hill Book Co., 2003. 
Hausman, J.A. "Individual Discount Rates and the Purchase and Utilization of EnergyUsing Durables." The Bell Journal of Economics 10, 1(1979): 33-54.

Hurley, T.M., D. Otto and J. Holtkamp. "Valuation of Water Quality in Livestock Regions: An Application to Rural Watersheds in Iowa." Journal of Agricultural and Applied Economics 31, 1(April 1999):177-184.

Jorgensen, B.S. and G.J. Syme. "Protest Responses and Willingness to Pay: Attitude toward Paying for Stormwater Pollution Abatement." Ecological Economics 33(2000):251-265.

Kennedy, P. A Guide to Econometrics, 5th ed. Cambridge, Massachusetts: The MIT Press, 2003.

King, D.M. and M. Mazzotta. 2005. "Ecosystem Valuation," Online website available at: http://www.ecosystemvaluation.org/contingent valuation.htm

Kruger, R.A. and M.A. Casey. Focus Groups, 3rd. ed. Thousand Oaks: Sage Publications, Inc., 2000.

Leone, R.A. and J.E Jackson. The Political Economy of Federal Regulatory Activity: The Case of Water-Pollution Controls, in Studies in Public Regulation. Cambridge, Mass.: MIT Press, 1981.

Lindsey, G. "Market Models, Protest Bids, and Outliers in Contingent Valuation." Journal of Water Resources Planning and Management 120, 1(1994): 121-129.

Loomis, J., T. Brown, B. Lucero, and G. Peterson. "Improving Validity Experiments of Contingent Valuation Methods: Results of Efforts to Reduce the Disparity of Hypothetical and Actual Willingness to Pay." Land Economics 72(1996):450-61.

Loomis, J., P. Kent, L. Strange, K. Fausch, A. Covich. "Measuring the Total Economic Value of Restoring Ecosystem Services in an Impaired River Basin: Results from a Contingent Valuation Survey." Ecological Economics 33(2000):103-117.

Lord Fairfax Soil and Water Conservation District. 2006. "LFSWCD," Online website available at: http://lfswcd.org/

MacDonald, H.F., J.C. Bergstrom and J.E. Houston. “A Proposed Methodology for Measuring Incremental Environmental Benefits from Using Constructed Wetlands to Control Non-Point-Source Pollution." Journal of Environmental Management 54(1998):259-267. 
McFadden, D., and G. Leonard. "Issues in the Contingent Valuation of Environmental Goods: Methodology for Data Collection and Analysis.” In J. Hausman, ed. Contingent Valuation: A Critical Assessment. Amsterdam: Elsevier, 1993.

Metcalf, G.E. and K.A. Hassett. "Measuring the Energy Savings from Home Improvements: Evidence from Monthly Billing Data." The Review of Economics and Statistics 81, 3(1999):516-528.

Mitchell, R.C. and R.T. Carson. Using Surveys to Value Public Goods: The Contingent Valuation Method. Washington, DC: Resources for the Future, 1989.

Moore, D.L. and J. Tarnai. Evaluating Nonresponse Error in Mail Surveys. New York: John Wiley and Sons, Inc., 2002.

Navrud, S. "Willingness to Pay for Preservation of Species: An Experiment with Actual Payments." In S. Navrud, ed. Pricing the European Environment. New York: Oxford University Press, 1992.

Poe, G.L. "Valuation of Groundwater Quality using a Contingent Valuation-Damage Function Approach.” Water Resources Research 34, 12(1998):3627-3633.

Polasky, S., O. Gainutdinova, and J. Kerkvliet. "Comparing CV Responses with Voting Behavior: Open Space Survey and Referendum in Corvallis Oregon.” Paper presented at the annual USDA W- 133 meeting, Jekyll Island, GA, February 1996.

Portney, P.R. "The Contingent Valuation Debate: Why Economists Should Care." Journal of Environmental Perspectives 8, 4(Fall 1994): 3-17.

Ready, R.C., J. Whitehead, and G. Blomquist. "Contingent Valuation when Respondents are Ambivalent." Journal of Environmental Economics and Management 29 (1995):181-96.

Rosenberger, R.S., A.R. Collins and J.B. Svetlik. "Private Provision of a Public Good: Willingness to Pay for Privately Stocked Trout." Society and Natural Resources 18(2005):75-87.

Samuelson, P. "The Pure Theory of Public Expenditures." Review of Economics and Statistics 36(1954):387-389.

Siep, K. and J. Strand. "Willingness to Pay for Environmental Goods in Norway: A Contingent Valuation Study with Real Payment." Environmental and Resource Economics 2, 1(1992):91-106. 
Snyder, C.D., J.A. Young, R. Villella, and D.P. Lemarie. "Influences of Upland and Riparian Land Use Patterns on Stream Biotic Integrity.” Landscape Ecology 18(2003):647-664.

Stumborg, B.E., K.A. Baerenklau, and R.C. Bishop. "Nonpoint Source Pollution and present Values: A Contingent Valuation Study of Lake Mendota." Review of Agricultural Economics 23, 1(2001):120-132.

Train, K. "Discount Rates in Consumer Energy Related Decisions: A Review of the Literature." Energy 10, 12(1985):1243-1253.

United States Census Bureau. 2000. "American Fact Finder," Online website available at: http://factfinder.census.gov

United States Department of Agriculture- Cooperative State Research, Education, and Extension Service. 2006. "Mid-Atlantic Regional Water Program," Online website available at: http://www.agnr.umd.edu/users/waterqual/

United States Environmental Protection Agency. 2006a. "Overview of Current TMDL," Online website available at: http://www.epa.gov/owow/tmdl/overviewfs.html . 2006b. "Environmental Protection Agency- Clean Water Act," Online website available at: http://www.epa.gov/region5/water/cwa.htm\#History . 2006c. "Environmental Protection Agency," Online website available at: http://oaspub.epa.gov/tmdl/waters_list.control . 2006d. "EPA History- Water," Online website available at: http://www.epa.gov/history/topics/fwpca/05.htm . 2005a. "EPA- Region 3- TMDLs," Online website available at: http://www.epa.gov/reg3wapd/tmdl/imp.htm . 2005b. "EPA > Total Maximum Daily Loads > Introduction to TMDLs," Online website available at: http://www.epa.gov/owow/tmdl/intro.html .2003. "Clean Water Act Module," Online website available at: http://www.epa.gov/watertrain/cwa/

United States Environmental Protection Agency, Office of Water. Water Quality Conditions in the United States. EPA-841-F-02-003, August 2002.

United States Environmental Protection Agency, Region III. Decision Rationale, Total Maximum Daily Loads for the Primary Contact use (Bacteriological) Impairments on Abrams and Opequon Creek. 
University of Virginia Institute for Environmental Negotiation, the Virginia Tech Center for Economic Education and the Virginia Department of Forestry. "Total Maximum Daily Loads: Balancing Water Quality and Public Safety," Online website available at: http://www.virginia.edu/ien/vnrli/docs/TMDL\%202006.pdf

Varian, H.R. Microeconomic Analysis, 2nd ed. New York: Norton, 1984.

Virginia Department of Environmental Quality, Virginia Department of Conservation and Recreation, Department of Biological Systems Engineering, Virginia Tech. Bacteria TMDLs for Abrams Creek and Upper and Lower Opequon Creek Located in Frederick and Clarke County Virginia. Revised January 2004. . Opequon Watershed TMDLs for Benthic Impairments: Abrams Creek and Lower Opequon Creek, Frederick and Clarke Counties, Virginia. Revised October 2003.

West Virginia Potomac Tributary Strategy. August 23rd, 2005.

Whitehead, J.C. "Demand-Side Factors and Environmental Equity Analysis.” Society \& Natural Resources 13(2000):75-81.

Wooldridge, J.M. Introductory Econometrics, 3rd ed. Mason, OH: Thomson SouthWestern, 2006. 


\section{APPENDICIES}

\section{A.1 Contingent Valuation Surveys}

\section{A.1.1 West Virginia General Public Survey}

\section{Section A:}

The first set of questions focuses on your use and knowledge of Opequon creek in West Virginia and your opinions about local environmental quality. Please answer these questions to the best of your ability.

1. With what portions of Opequon Creek, if any, are you familiar? (Please check all that apply) Please see the map on the back page of this booklet for reference, and note that this creek starts in Virginia and flows north through West Virginia into the Potomac River.

The portion of Opequon Creek in Virginia as it flows from its headwaters to the Virginia/West Virginia state line.

The portion of Opequon Creek in West Virginia from the state line to the Potomac River.

I am not familiar with any portion of Opequon Creek.

2. Have you ever used Opequon Creek for fishing, swimming, wading, hiking along, exploring, wildlife watching, kayaking or canoeing? (Please check one)

Yes

No

3. Based upon what you know about Opequon Creek, do you think there are environmental problems associated with this creek? (Please check one)

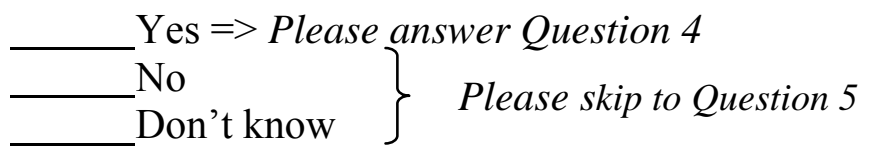

4. If you answered "Yes" in Question 3, what environmental problems are you aware of on Opequon Creek? (Please check all that apply)

Trash

Livestock

Lack of recreational opportunities

Flooding and/or storm water runoff

Sewage

Dirt or sediment in water

Other, please specify 
5. How concerned are you about the ability of fish and other aquatic life to survive in Opequon Creek? (Please check one)

Very concerned

Some what concerned

Not concerned at all

6. In which of the following outdoor activities, if any, do you regularly participate?

(Please check all that apply)

Fish in a lake, river, or creek

Swim in a lake, river, or creek

Explore or wade along a river/creek

Kayak or canoe

Wildlife viewing

None of these

7. When you think about growth in and around your community, what is the first thought that comes to mind? (Please check one)

More jobs

Increased congestion

More shopping and entertainment opportunities

Environmental problems

The need to manage growth to protect quality of life

Increased tax burdens on existing residents

Other, please specify

8. In the past few years, what would you say has happened to the overall quality of the environment in your area? (Please check one)

Improved

Stayed the same

Gotten worse

Don't know

\section{Section B:}

In this section, you will be asked to consider a proposed project that would cleanup Opequon Creek. This is not an actual referendum. Please answer the question as though you were actually voting on the issue considering your current budget. 
9(a) Financial support for clean-up of Opequon Creek in West Virginia:

Opequon Creek is currently polluted with excessive nutrients and bacteria from sources such as agriculture, urban runoff, and sewage occurring in West Virginia. Because of these pollutants, no swimming or wading is recommended in Opequon Creek. While this creek is stocked annually with trout, not all portions of the creek can support year-round sport fish populations (bass, bluegill, trout, etc.).

Assume that you are asked to vote on a project that would provide the funding required to clean-up Opequon Creek. In about five years, this clean-up would make Opequon Creek safe for swimming and wading. It would also provide habitat for year-round fish populations. This project would raise county taxes over a five year period in order to pay for the clean-up project. Would you support, oppose, or remain neutral about this project? (Please check one)

Support (Please answer Question 9(b) and then skip to Question 11) Oppose Remain neutral/ not participate

(Please skip Question 9(b) and answer Question 10)

9(b) If you support the proposed project, what is the highest level of taxes that you would be willing to pay each year, for five years, to clean-up Opequon Creek? (Please circle one)

$\begin{array}{lllll}\$ 0 & \$ 5 & \$ 10 & \$ 15 & \$ 20 \\ \$ 25 & \$ 30 & \$ 40 & \$ 50 & \$ 75 \\ \$ 100 & \$ 125 & \$ 150 & \$ 200 & \$ 300\end{array}$

$\$ 500 \quad \$ 1,000 \quad$ Other, please specify $\$$

(Please skip to Question 11) 
10. If you oppose or remain neutral about this clean-up project, which statement best reflects why you would not be willing to provide financial support for clean-up of Opequon Creek? (Please check one)

I support the clean-up of Opequon Creek, but cannot afford higher taxes at this time.

I support the clean-up of Opequon Creek, but I think someone else should pay for it.

I support the clean-up of Opequon Creek, but I don't think taxes are the best way to pay for it.

I support the clean-up of Opequon Creek, but I think it cannot be accomplished as described in Question 9(a). I support improvement of Opequon Creek, but I think that excessive nutrients and bacteria from urban runoff and sewage are not environmental problems in this creek.

I think Opequon Creek is okay the way it is. Other, please specify

11. After cleaning up Opequon Creek, what other improvements, if any, would you like to see along this creek? (Please check all that apply)

Walking or biking trails

Public access for fishing and recreation

Regular trash clean-up

Protection of forests along the creek

None

Other, please specify

12. How much do you trust the following groups or institutions to make decisions about what should be done to clean-up Opequon Creek? (Please check one box per row to indicate a level of trust.)

\begin{tabular}{|l|l|l|l|l|}
\hline & $\underline{\text { Trust }}$ & $\underline{\underline{\text { Somewhat }}}$ & $\underline{\text { Distrust }}$ & $\frac{\text { Neutral/ }}{\text { Don't know }}$ \\
\hline University scientists & & & & \\
\hline $\begin{array}{l}\text { Watershed organizations } \\
\text { like Sleepy Creek } \\
\text { Watershed Association }\end{array}$ & & & & \\
\hline Local government & & & & \\
\hline County extension agents & & & & \\
\hline
\end{tabular}




\begin{tabular}{|l|l|l|l|l|}
\hline $\begin{array}{l}\text { Local soil \& water } \\
\text { conservation districts such } \\
\text { as the Eastern Panhandle }\end{array}$ & & & & \\
Conservation District & & & & \\
\hline $\begin{array}{l}\text { State agencies such as } \\
\text { West Virginia Department } \\
\text { of Environmental }\end{array}$ & & & & \\
Protection & & & & \\
\hline
\end{tabular}

In the next question, you will be asked to consider donating to a fund that would clean-up Opequon Creek and its tributaries in Virginia. Similar to Question 9(a), this is not an actual request. Please answer the question considering your current family budget.

\section{Financial support for clean-up of Opequon Creek in Virginia:}

Opequon Creek in Virginia is currently polluted with dirt and sediment, as well as with sewage and bacteria. Clean-up on the West Virginia (WV) side would not solve pollution problems in Virginia (VA). Because of these pollutants, no swimming or wading is recommended in the VA portion of Opequon Creek.

Assume that in addition to cleaning up Opequon Creek in WV, you are asked to participate in cleaning up the VA portion of Opequon Creek by donating to an Opequon Creek Restoration Fund. Recall that since the creek flows from VA to WV, improving water quality on the VA side will result in cleaner water on the WV side (the amount of improvement is unknown). The money from this fund would be used to make water quality in Opequon Creek in VA safe for swimming and wading.

What is the highest one-time donation you would be willing to pay for clean-up of the Virginia portion of Opequon Creek? (Please circle one)

$\$ 0$ $\$ 5$

$\$ 10$

$\$ 15$

$\$ 20$

$\$ 25$

$\$ 30$

$\$ 40$

$\$ 50$

$\$ 75$

$\$ 100$

$\$ 125$

$\$ 150$

$\$ 200$

$\$ 300$

$\$ 500$

$$
\$ 1,000
$$

Other, please specify \$

\section{Section C:}

We would like to finish up this survey with some questions about you. These questions are for research purposes only. The information that you provide will remain confidential and will not be shared with any business or other institution.

What is your gender? Male Female 
What is your year of birth? 19

What is your highest level of education? (Please check one)

Less than a high school diploma

High school diploma or GED

Some college/technical school

College degree

Graduate school

What type of land do you own in the watershed area shown on the map on the back page of this booklet? (Please check all that apply)

Home or residential

Agricultural

Commercial

Riparian (stream side) land

None

Other, please specify

How long have you been a resident of the watershed area shown on the map on the back page of this booklet? (Please check one)

Less than 1 year

Between 1 and 10 years

Longer that 10 years

All my life

What was your total household income for 2004? (Please check one)

Under $\$ 10,000$

$\$ 10,000-\$ 24,999$

$\$ 25,000$ - \$49,999

$\$ 50,000-\$ 99,999$

$\$ 100,000-\$ 199,999$

$\$ 200,000$ or more

Thank you for participating in this survey! Your time is appreciated! Please return this survey in the addressed envelope provided. No postage is required. If you would like to be sent a written report of the results, please fill in your name and address below.

Alternatively, you could use this space for comments, if any: 


\section{A.1.2 Virginia General Public Survey}

\section{Section A:}

The first set of questions focuses on your use and knowledge of selected creeks in Virginia and your opinions about local environmental quality. Please answer these questions to the best of your ability.

1. With what portions of Opequon and Abrams Creeks, if any, are you familiar (please check all that apply)? Please see the map on the back page of this booklet for reference, and note that Opequon creek starts in Virginia and flows north through West Virginia into the Potomac River.

The upper portion of Opequon Creek as it flows from its headwaters to the junction with Abrams Creek. Any portion of Abrams Creek.

The lower portion of Opequon Creek as it flows from the junction with Abrams Creek to the Virginia/West Virginia state line. The portion of Opequon Creek in West Virginia. I am not familiar with any portion of Opequon and Abrams Creeks.

2. Have you ever used Opequon or Abrams Creeks for fishing, swimming, wading, hiking along, exploring, wildlife watching, kayaking or canoeing? (Please check one)

Yes No

3. Based upon what you know about Opequon and Abrams Creeks, do you think there are environmental problems associated with these creeks? (Please check one)

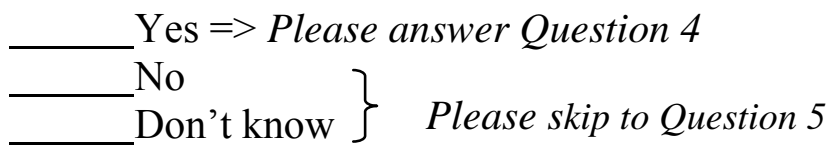

4. If you answered "Yes" in Question 3, what environmental problems are you aware of on Opequon and/or Abrams Creeks? (Please check all that apply)

Trash

Livestock

Lack of recreational opportunities

Flooding and/or storm water runoff

Sewage

Dirt or sediment in water

Other, please specify 
5. How concerned are you about the ability of fish and other aquatic life to survive in Opequon and Abrams Creeks? (Please check one)

Very concerned

Some what concerned

Not concerned at all

6. A total maximum daily load (TMDL) is a written plan, created by the Virginia Department of Environmental Quality that specifies the maximum amount of pollution that a creek, like Opequon or Abrams, can receive and still be considered clean. Are you aware that a TMDL has been developed for Opequon and Abrams Creeks? (Please check one)

Yes No

7. In which of the following outdoor activities, if any, do you regularly participate?

(Please check all that apply)

Fish in a lake, river, or creek

Swim in a lake, river, or creek

Explore or wade along a river/creek

Kayak or canoe

Wildlife viewing

None of these

8. When you think about growth in and around your community, what is the first thought that comes to mind? (Please check one)

More jobs Increased congestion

More shopping and entertainment opportunities

Environmental problems

The need to manage growth to protect quality of life Increased tax burdens on existing residents Other, please specify

9. In the past few years, what would you say has happened to the overall quality of the environment in your area? (Please check one)

Improved

Stayed the same

Gotten worse

Don't know 


\section{Section B:}

In this section, you will be asked to consider a proposed project that would cleanup Opequon and Abrams Creeks. This is not an actual referendum. Please answer the question as though you were actually voting on the issue considering your current family budget.

10(a) Financial support for clean-up of Opequon and Abrams Creeks in Virginia:

Opequon and Abrams Creeks are currently polluted with dirt and sediment along with sewage and bacteria. Because of these pollutants, no swimming or wading is recommended in the Virginia portion of these Creeks.

Assume that you are asked to vote on a project that would provide the funding required to clean-up Opequon and Abrams Creeks. In approximately five years, this clean-up would make Opequon and Abrams Creeks safe for swimming and wading in the Virginia portion. This project would raise local taxes over a five year period in order to pay for the clean-up project. Would you support, oppose, or remain neutral about this project? (Please check one)

Support (Please answer Question 10(b) and then skip to Question 12) Oppose Remain neutral/not participate $\} \quad \begin{aligned} & \text { (Please skip Question 10(b) } \\ & \text { and answer Question 11) }\end{aligned}$

10(b) If you support the proposed project, what is the highest level of taxes that you would be willing to pay annually (per year) for five years to clean-up Opequon and Abrams Creeks? (Please circle one)

\begin{tabular}{lllll}
$\$ 0$ & $\$ 5$ & $\$ 10$ & $\$ 15$ & $\$ 20$ \\
$\$ 25$ & $\$ 30$ & $\$ 40$ & $\$ 50$ & $\$ 75$ \\
$\$ 100$ & $\$ 125$ & $\$ 150$ & $\$ 200$ & $\$ 300$ \\
$\$ 500$ & $\$ 1,000$ & Other, please specify $\$ —$ & \\
& & \multicolumn{2}{r}{ (Please skip to Question 12) }
\end{tabular}


11. If you oppose or remain neutral about this clean-up project, which statement best reflects why you would not be willing to provide financial support for clean-up of Opequon and Abrams Creeks? (Please check one)

I support clean-up of Opequon and Abrams Creeks, but cannot afford higher taxes at this time.

I support the clean-up of Opequon and Abrams Creeks, but I think someone else should pay for it. I support the clean-up of Opequon and Abrams Creeks, but I don't think taxes are the best way to pay for it. I support the clean-up of Opequon and Abrams Creeks, but I think it cannot be accomplished as described in Question 10(a). I support improvement of Opequon and Abrams Creeks, but I think that dirt and sediment plus bacteria are not environmental problems in these creeks.

I think Opequon and Abrams Creeks are okay the way they are. Other, please specify

12. After cleaning up Opequon and Abrams Creeks, what other improvements, if any, would you like to see along these creeks? (Please check all that apply)

Walking or biking trails

Public access for fishing and recreation

Regular trash clean-ups

Fish stocking

Protection of forests along the creeks

None

Other, please specify

13. How much do you trust the following groups or institutions to make decisions about what should be done to clean-up Opequon and Abrams Creeks? (Please check one box per row to indicate a level of trust.)

\begin{tabular}{|l|l|l|l|l|}
\hline & $\underline{\text { Trust }}$ & $\frac{\underline{\text { Somewhat }}}{\underline{\text { trust }}}$ & $\underline{\text { Distrust }}$ & $\underline{\underline{\text { Neutral/ }}}$ \\
Don't know \\
\hline University scientists & & & & \\
\hline $\begin{array}{l}\text { Watershed organizations } \\
\text { like Friends of Shenandoah }\end{array}$ & & & & \\
\hline Local government & & & & \\
\hline County extension agents & & & & \\
\hline
\end{tabular}




\begin{tabular}{|l|l|l|l|l|}
\hline $\begin{array}{l}\text { Local soil \& water } \\
\text { conservation districts such } \\
\text { as Lord Fairfax Soil and } \\
\text { Water Conservation District }\end{array}$ & & & & \\
\hline $\begin{array}{l}\text { State agencies such as } \\
\text { Virginia Department of }\end{array}$ & & & & \\
Environmental Quality & & & & \\
\hline
\end{tabular}

In the next question, you will be asked to consider donating to a fund that would clean-up Opequon Creek in West Virginia. Similar to Question 10(a), this is not an actual request. Please answer the question considering your current family budget.

\section{Financial support for clean-up of Opequon Creek in West Virginia:}

Opequon Creek is currently polluted with excessive nutrients and bacteria from sources such as agriculture, urban runoff, and sewage occurring in West Virginia. Clean-up on the Virginia side would not solve pollution problems in West Virginia. Because of these pollutants, no swimming or wading is recommended in the West Virginia portion of Opequon Creek. While this creek is stocked annually with trout, not all portions of the creek can support year-round sport fish populations (bass, bluegill, trout, etc.).

Assume that in addition to cleaning up Opequon and Abrams Creeks in Virginia, you are asked to participate in cleaning up the West Virginia portion of Opequon Creek by donating to an Opequon Creek Restoration Fund. West Virginia residents also would be asked to contribute to this restoration fund. Money from this fund would be used to make water quality in Opequon Creek in West Virginia safe for swimming and wading. The money also would be used to create habitat for year-round sport fish populations

What is the highest one-time donation you would be willing to pay for a clean-up of the West Virginia portion of Opequon Creek? (Please circle one)

$\begin{array}{lllll}\$ 0 & \$ 5 & \$ 10 & \$ 15 & \$ 20 \\ \$ 25 & \$ 30 & \$ 40 & \$ 50 & \$ 75 \\ \$ 100 & \$ 125 & \$ 150 & \$ 200 & \$ 300 \\ \$ 500 & \$ 1,000 & \text { Other, please specify } \$ & \end{array}$

\section{Section C:}

We would like to finish up this survey with some questions about you. These questions are for research purposes only. The information that you provide will remain confidential and will not be shared with any business or other institution.

What is your gender? Male Female 
What is your year of birth? 19

What is your highest level of education? (Please check one)

Less than a high school diploma

High school diploma or GED

Some college/technical school

College degree

Graduate school

What type of land do you own in the watershed area shown on the map on the back page of this booklet? (Please check all that apply)

Home or residential Agricultural

Commercial

Riparian (stream side) land

None Other, please specify

How long have you been a resident of the watershed area shown on the map on the back page of this booklet? (Please check one)

Less than 1 year

Longer than 10 years

Between 1 and 10 years

All my life

What was your total household income for 2004? (Please check one)

Under $\$ 10,000$

$\$ 10,000-\$ 24,999$

$\$ 25,000-\$ 49,999$
$\$ 50,000$ - $\$ 99,999$

$\$ 100,000$ - \$199,999

$\$ 200,000$ or more

Thank you for participating in this survey! Your time is appreciated! Please return this survey in the addressed envelope provided. No postage is required. If you would like to be sent a written report of the results, please fill in your name and address below. Alternatively, you could use this space for comments, if any: 


\section{A.1.3 Virginia Riparian Landowner Survey}

\section{Section A:}

In this section, you will be asked if you own land in the Opequon/ Abrams Creek watershed area that has a stream or creek, which runs through it. If you answer "Yes", please answer Questions 1, 2, and 3. If you answer "No", please skip to Section $B$.

Do you own land in the watershed area (please see the map on the back of this survey) that has a creek or stream that runs through it? (Please check one)

Yes $=>$ What is the name of the creek or stream?

If you answered “Yes”, please also answer Questions 1, 2, and 3.

No $=>$ Please skip to Section B

1. Which of the following concerns do you have about this stream or creek? (Please check all that apply)

Stream pollution

Stream bank erosion

Stream course changes

Trash in the stream

Flooding

Wildlife

Recreational users who fish, kayak, canoe, etc.

2. Which of the following stream improvement projects would you consider doing at your own expense on your stream-front property? (Please check all that apply)

Stream bank restoration

Tree planting beside the stream

Fencing to exclude domestic livestock

Allowing public access for fishing and/or recreation

Conservation easements along a stream

None of the above 
3. Which of the following stream improvement projects would you consider doing with government cost share on your stream-front property? (Please check all that apply)

Stream bank restoration

Tree planting beside the stream

Fencing to exclude domestic livestock

Allowing public access for fishing and recreation

Conservation easements along a stream

None of the above

\section{Section B:}

This set of questions focuses on your use and knowledge of selected creeks in Virginia and your opinions about local environmental quality. Please answer these questions to the best of your ability.

4. With what portions of Opequon and Abrams Creeks, if any, are you familiar (please check all that apply)? Please see the map on the back page of this booklet for reference, and note that Opequon creek starts in Virginia and flows north through West Virginia into the Potomac River.

The upper portion of Opequon Creek as it flows from its headwaters to the junction with Abrams Creek. Any portion of Abrams Creek.

The lower portion of Opequon Creek as it flows from the junction with Abrams Creek to the Virginia/West Virginia state line. The portion of Opequon Creek in West Virginia. I am not familiar with any portion of Opequon and Abrams Creeks.

5. Have you ever used Opequon or Abrams Creeks for fishing, swimming, wading, hiking along, wildlife watching, exploring, kayaking or canoeing? (Please check one)

Yes No

6. Based upon what you know about Opequon and Abrams Creeks, do you think there are environmental problems associated with these creeks? (Please check one)

Yes $=>$ Please answer Question 7

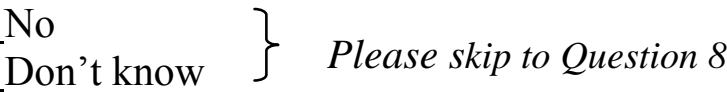


7. If you answered "Yes" in Question 6, what environmental problems are you aware of on Opequon and/or Abrams Creeks? (Please check all that apply)

Trash Lack of recreational opportunities Flooding and/or storm water runoff Other, please specify
Livestock Sewage Dirt/sediment in water

8. How concerned are you about the ability of fish and other aquatic life to survive in Opequon and Abrams Creeks? (Please check one)

Very concerned

Some what concerned

Not concerned at all

9. A total maximum daily load (TMDL) is a written plan, created by the Virginia Department of Environmental Quality that specifies the maximum amount of pollution that a creek, like Opequon or Abrams, can receive and still be considered clean. Are you aware that a TMDL has been developed for Opequon and Abrams Creeks? (Please check one)

Yes No

10. In which of the following outdoor activities, if any, do you regularly participate? (Please check all that apply)

Fish in a lake, river, or creek Swim in a lake, river, or creek Explore or wade along a river/creek Kayak or canoe Wildlife viewing None of these

11. When you think about growth in and around your community, what is the first thought that comes to mind? (Please check one)

More jobs

Increased congestion

More shopping and entertainment opportunities

Environmental problems

The need to manage growth to protect quality of life

Increased tax burdens on existing residents

Other, please specify 
12. In the past few years, what would you say has happened to the overall quality of the environment in your area? (Please check one)

Improved

Stayed the same

Gotten worse

Don't know

\section{Section C:}

In this section, you will be asked to consider a proposed project that would cleanup Opequon and Abrams Creeks. This is not an actual referendum. Please answer the question as though you were actually voting on the issue considering your current family budget.

13(a) Financial support for clean-up of Opequon and Abrams Creeks in Virginia:

Opequon and Abrams Creeks are currently polluted with dirt and sediment along with sewage and bacteria. Because of these pollutants, no swimming or wading is recommended in the Virginia portion of these creeks.

Assume that you are asked to vote on a project that would provide the funding required to clean-up Opequon and Abrams Creeks. In about five years, this clean-up would make Opequon and Abrams Creeks safe for swimming and wading in the Virginia portion. This project would raise local taxes over a five year period in order to pay for the clean-up project. Would you support, oppose, or remain neutral about this project? (Please check one)

Support (Please answer Question 13(b) and then skip to Question 15) Oppose Remain neutral/not participate $\} \quad$ (Please skip Question 13(b) and answer Question 14)

13(b) If you support the proposed project, what is the highest level of taxes that you would be willing to pay annually (per year) for five years to clean-up Opequon and Abrams Creeks? (Please circle one)

$\begin{array}{lllll}\$ 0 & \$ 5 & \$ 10 & \$ 15 & \$ 20 \\ \$ 25 & \$ 30 & \$ 40 & \$ 50 & \$ 75 \\ \$ 100 & \$ 125 & \$ 150 & \$ 200 & \$ 300\end{array}$

$\$ 500 \quad \$ 1,000 \quad$ Other, please specify $\$$

Please skip to Question 15 
14. If you oppose or remain neutral about this clean-up project, which statement best reflects why you would not be willing to provide financial support for clean-up of Opequon and Abrams Creeks? (Please check one)

I support clean-up of Opequon and Abrams Creeks, but cannot afford higher taxes at this time.

I support the clean-up of Opequon and Abrams Creeks, but I think someone else should pay for it. I support the clean-up of Opequon and Abrams Creeks, but I don't think taxes are the best way to pay for it. I support the clean-up of Opequon and Abrams Creeks, but I think it cannot be accomplished as described in Question 13(a). I support improvement of Opequon and Abrams Creeks, but I think that dirt and sediment plus bacteria are not environmental problems in these creeks.

I think Opequon and Abrams Creeks are okay the way they are. Other, please specify

15. After cleaning up Opequon and Abrams Creeks, what other improvements, if any, would you like to see along these creeks? (Please check all that apply)

Walking or biking trails

Public access for fishing and recreation

Regular trash clean-up

Fish stocking

Protection of forests along the creeks

None

Other, please specify

16. How much do you trust the following groups or institutions to make decisions about what should be done to clean-up the Opequon and Abrams Creeks? (Please check one box per row to indicate a level of trust.)

\begin{tabular}{|l|l|l|l|l|}
\hline & $\underline{\text { Trust }}$ & $\underline{\underline{\text { Somewhat }}}$ & $\underline{\text { Distrust }}$ & $\underline{\underline{\text { Neutral/ }}}$ \\
\hline University scientists & & & & \\
\hline $\begin{array}{l}\text { Watershed organizations } \\
\text { like Friends of Shenandoah }\end{array}$ & & & & \\
\hline Local government & & & & \\
\hline County extension agents & & & & \\
\hline
\end{tabular}




\begin{tabular}{|l|l|l|l|l|}
\hline $\begin{array}{l}\text { Local soil \& water } \\
\text { conservation districts such } \\
\text { as Lord Fairfax Soil and }\end{array}$ & & & & \\
Water Conservation District & & & & \\
\hline $\begin{array}{l}\text { State agencies such as } \\
\text { Virginia Department of }\end{array}$ & & & & \\
Environmental Quality & & & & \\
\hline
\end{tabular}

In the next question, you will be asked to consider donating to a fund that would clean-up Opequon Creek in West Virginia. Similar to Question 13(a), this is not an actual request, but please answer the question considering your current family budget.

17. Financial support for clean-up of Opequon Creek in West Virginia:

Opequon Creek is currently polluted with excessive nutrients and bacteria from sources such as agriculture, urban runoff, and sewage occurring in West Virginia. Clean-up on the Virginia side would not solve pollution problems in West Virginia. Because of these pollutants, no swimming or wading is recommended in the West Virginia portion of Opequon Creek. While this creek is stocked annually with trout, not all portions of the creek can support year-round sport fish populations (bass, bluegill, trout, etc.).

Assume that in addition to cleaning up Opequon and Abrams Creeks in Virginia, you are asked to participate in cleaning up the West Virginia portion of Opequon Creek by donating to an Opequon Creek Restoration Fund. West Virginia residents also would be asked to contribute to this restoration fund. Money from this fund would be used to make water quality in Opequon Creek in West Virginia safe for swimming and wading. The money also would be used to create habitat for year-round sport fish populations

What is the highest one-time donation you would be willing to pay for a clean-up of the West Virginia portion of Opequon Creek? (Please circle one)

$\begin{array}{lllcc}\$ 0 & \$ 5 & \$ 10 & \$ 15 & \$ 20 \\ \$ 25 & \$ 30 & \$ 40 & \$ 50 & \$ 75 \\ \$ 100 & \$ 125 & \$ 150 & \$ 200 & \$ 300 \\ \$ 500 & \$ 1,000 & \text { Other, please specify } \$ & \end{array}$

\section{Section D:}

We would like to finish up this survey with some questions about you. These questions are for research purposes only. The information that you provide will remain confidential and will not be shared with any business or other institution. 
What is your gender?

Male

Female

What is your year of birth? 19

What is your highest level of education? (Please check one)

Less than a high school diploma

High school diploma or GED

Some college/technical school

College degree

Graduate school

What type of land do you own in the watershed area shown on the map on the back page of this booklet? (Please check all that apply)

Home or residential

Commercial

None
Agricultural

Riparian (stream side) land

Other, please specify

How long have you been a resident of the watershed area shown on the map on the back page of this booklet? (Please check one)

Less than 1 year

Longer than 10 years
Between 1 and 10 years

All my life

What was your total household income for 2004? (Please check one)

Under $\$ 10,000$

$\$ 10,000$ - \$24,999

$\$ 25,000-\$ 49,999$
$\$ 50,000$ - $\$ 99,999$

$\$ 100,000$ - \$199,999

$\$ 200,000$ or more

Thank you for participating in this survey! Your time is appreciated! Please return this survey in the addressed envelope provided. No postage is required. If you would like to be sent a written report of the results, please fill in your name and address below. Alternatively, you could use this space for comments, if any: 


\section{A.2 Additional Survey Materials}

\section{A.2.1 Cover Letter}

We would like to invite you to participate in a research survey about improving water quality in selected creeks (Opequon and Abrams Creeks) in your area. We understand how busy you are and appreciate you taking time to consider participating in this survey. Your input is important to properly estimate the benefits to your community from improving both creeks. Your name was selected at random from a mailing list of riparian landowners.

This survey should take about 15 minutes to complete. Please return the completed survey in the enclosed envelope (NO POSTAGE IS REQUIRED). All information you provide will remain confidential and will not be shared with any business or other institution. You do not have to answer every question and your participation in this survey is completely voluntary. The only data released to the public will be in a form where individual responses can not be identified.

If you have any questions regarding this survey, please contact a Virginia Extension Agent at 540-665-5699 or Alan Collins at 304-293-4832 ext. 4473

(alan.collins@mail.wvu.edu). Later this fall, a written report of the survey results will be made available online at:

http://www.cafcs.wvu.edu/resm/faculty/borisova/OpequonProject.htm. Additional information about this survey can also be obtained through this website.

Thank you for considering our request.

Sincerely,

Jim Lawrence

Project Coordinator

Winchester Green Circle
Alan Collins

Associate Professor

Agricultural and Resource Economics 


\section{A.2.2 Follow-up Postcard}

September $21^{\text {st }}, 2005$

Several weeks ago, you received a mail survey titled, "Water Quality Survey Summer 2005." If you have completed and returned the survey, thank you for your assistance! Survey results should be ready by late 2005 .

If you have not yet completed and returned the survey, please take a few minutes to do so. Your response would be greatly appreciated! Additional information about this survey and a copy of the survey can also be obtained online at: http://www.cafcs.wvu.edu/resm/faculty/borisova/OpequonProject.htm.

If you have any questions regarding this survey, please contact a Virginia Extension Agent at (540) 665-5699 or Alan Collins at (304) 293-4832 ext. 4473 or alan.collins@mail.wvu.edu.

Sincerely,

Alan Collins Associate Professor

Agricultural and Resource Economics
Jim Lawrence Project Coordinator Winchester Green Circle 


\section{A.3. LIMDEP Estimation Final Grouped Tobit Results}

\section{A.3.1 Comparing Sub-Samples: West Virginia General Public (WVGP) and Virginia General Public (VAGP) WTP for In-State Clean-up.}

WVGP Results:

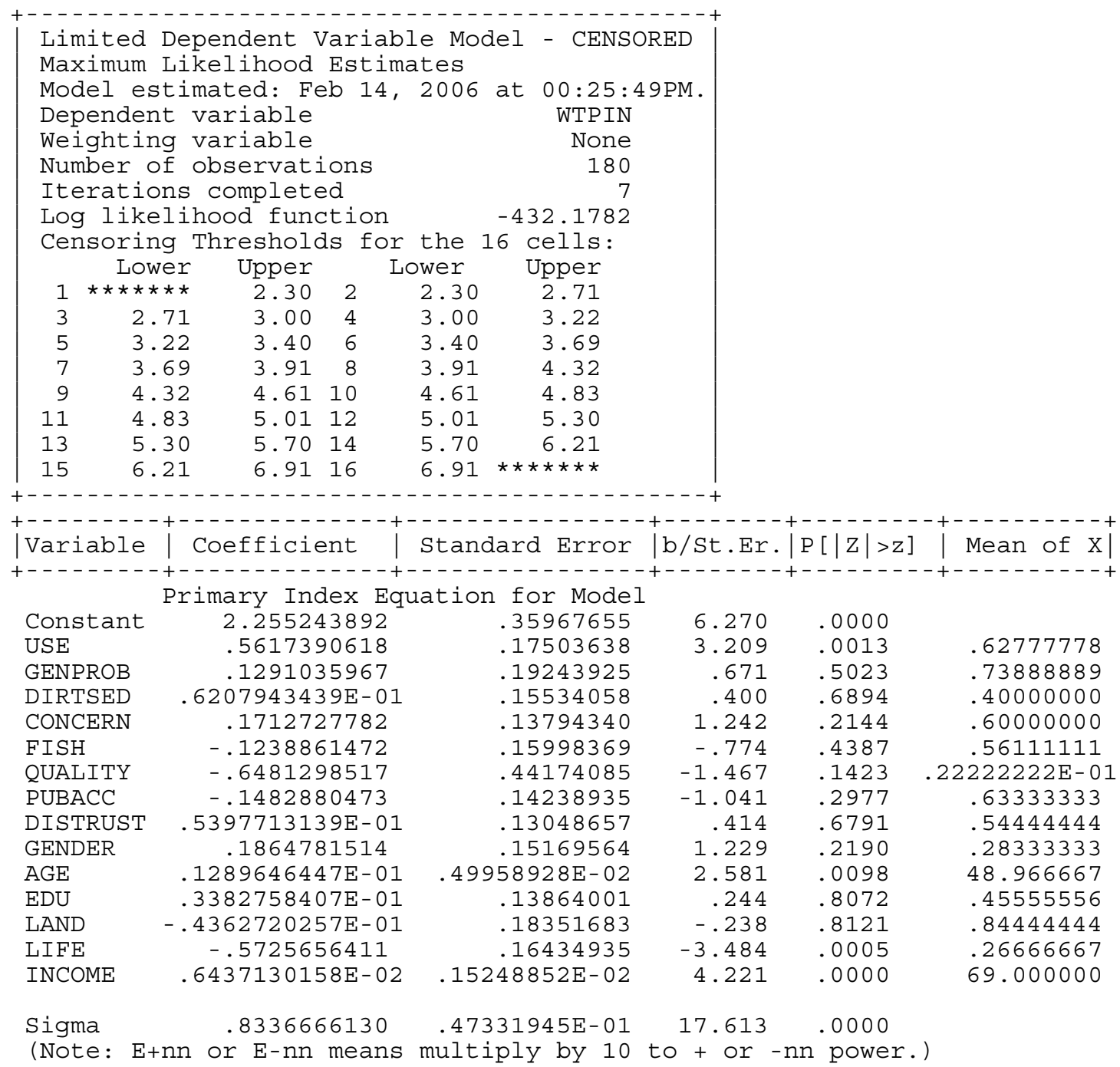

Matrix: Las

$[16,4]$ 


\section{VAGP Results:}

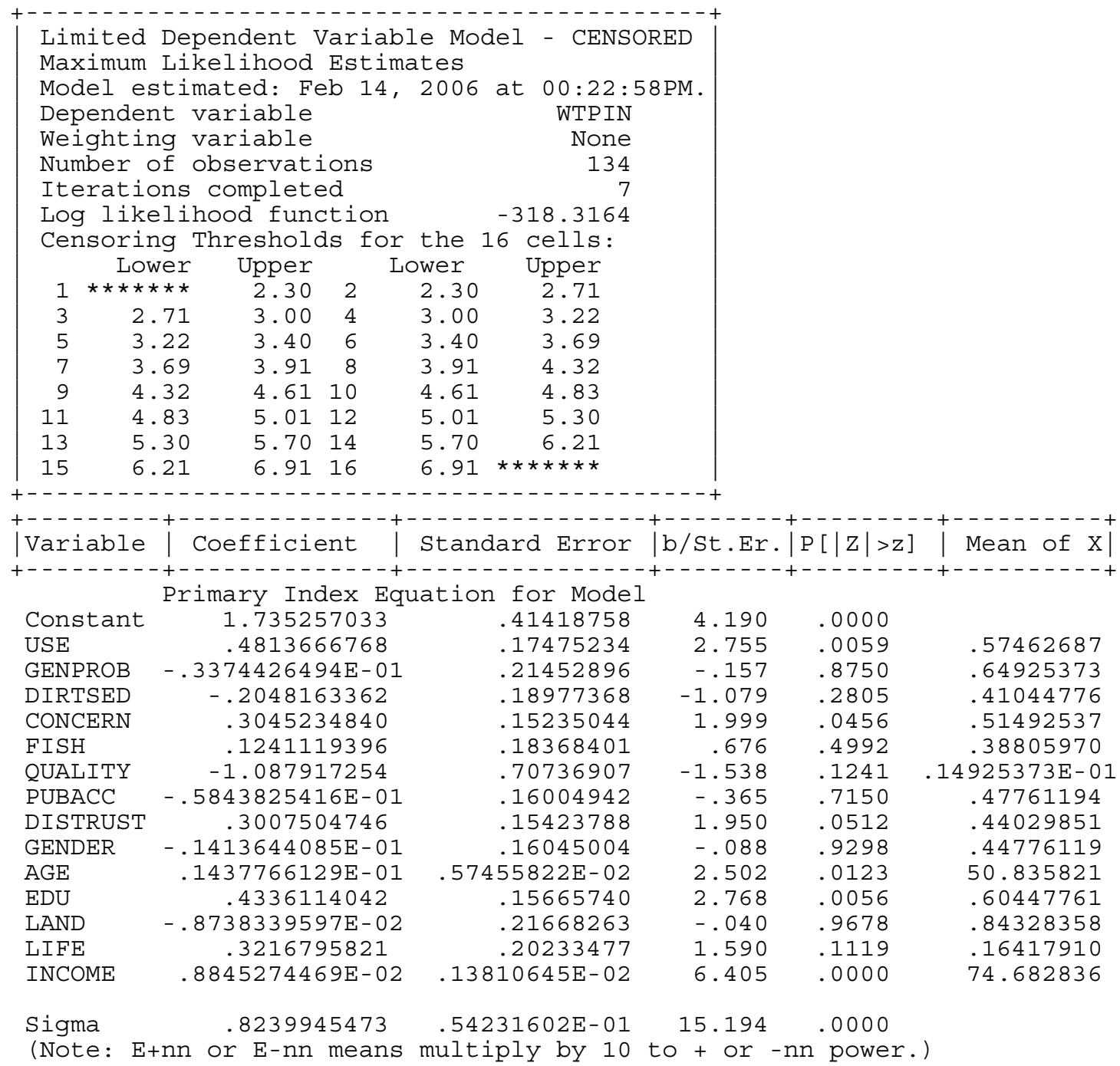

Matrix: La:

[16,4] 


\section{Pooled (WVGP + VAGP) Results:}

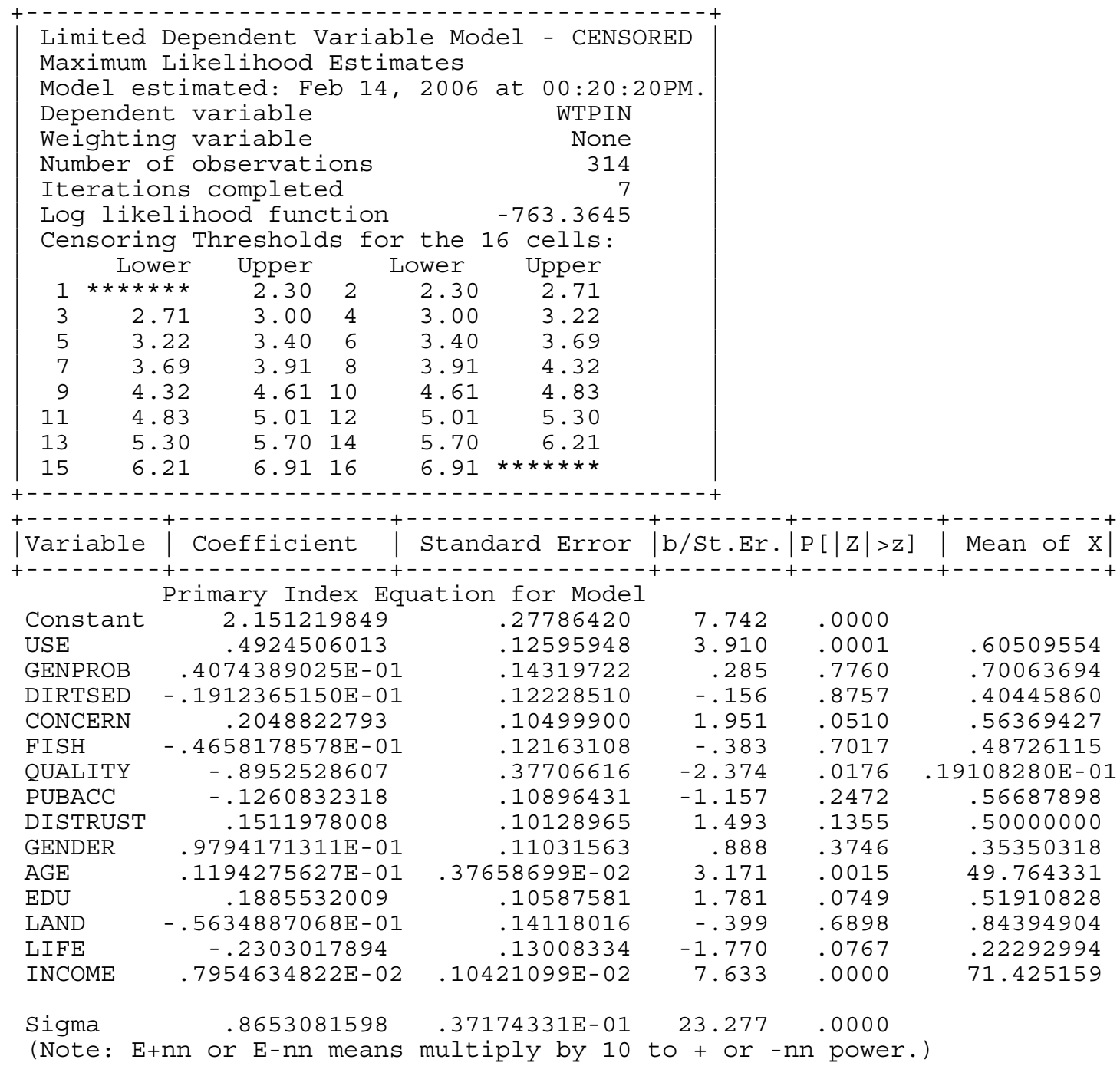

Matrix: La:

$[16,4]$ 


\section{A.3.2 Virginia General Public WTP for In-State Clean-up Final Results.}

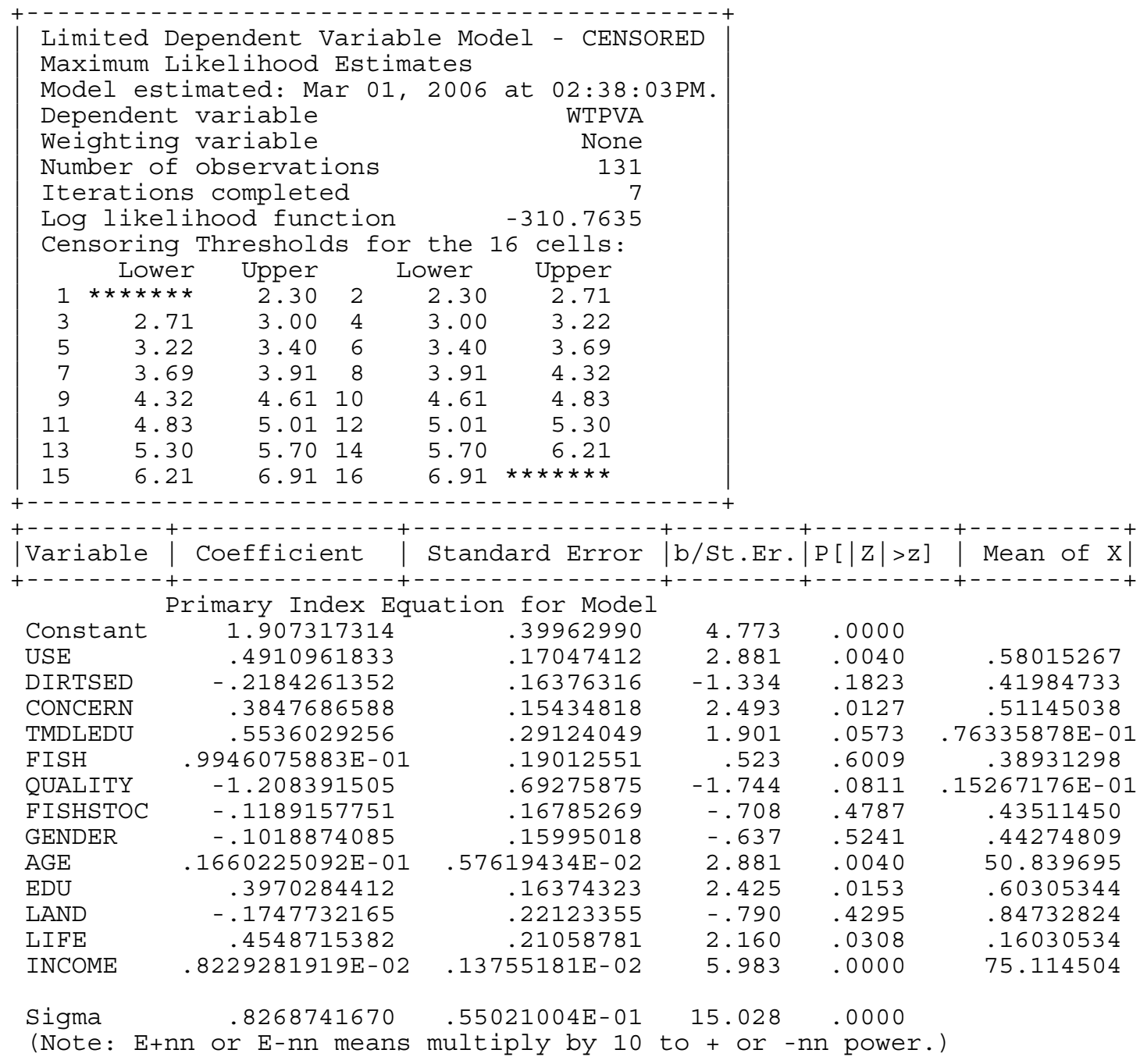

Matrix: La

$[15,4]$ 


\title{
A.3.3 Comparing Sub-Samples: Virginia General Public (VAGP) and Virginia Riparian Landowner (VARL) WTP for In-State Clean-up.
}

\author{
VAGP Results:
}

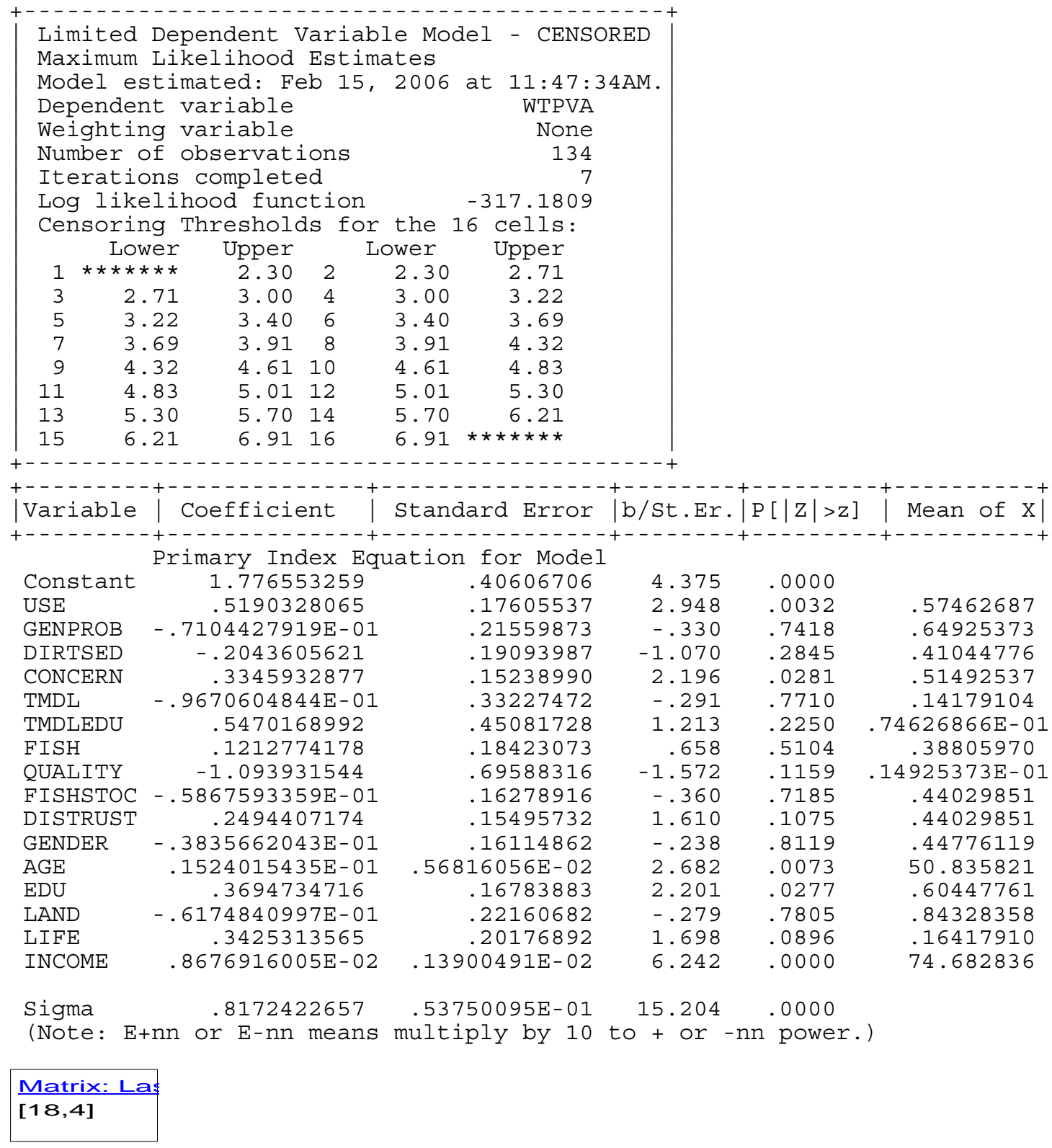




\section{VARL Results:}

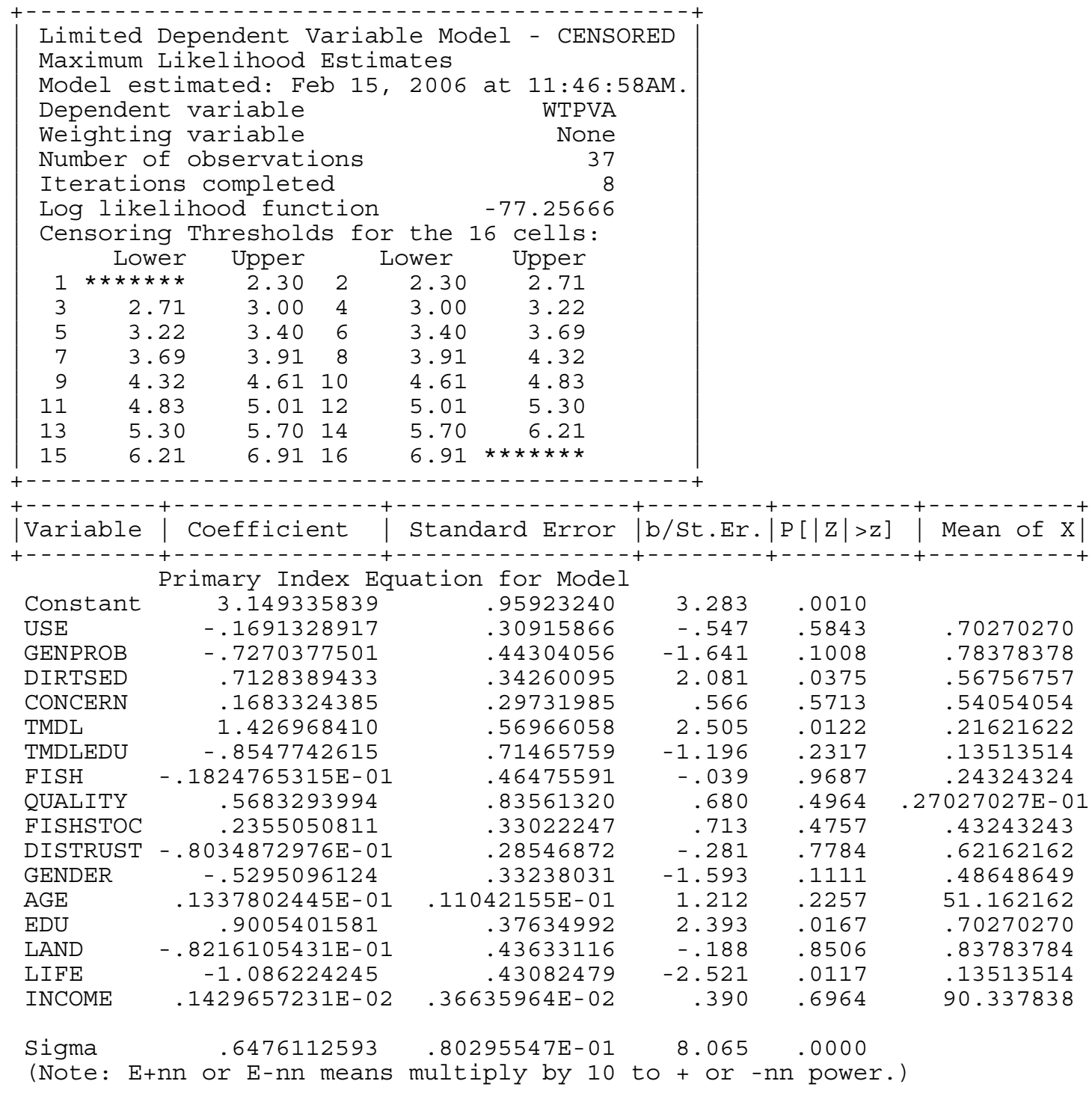

Matrix: La

$[18,4]$ 


\section{Pooled (VAGP + VARL) Results:}

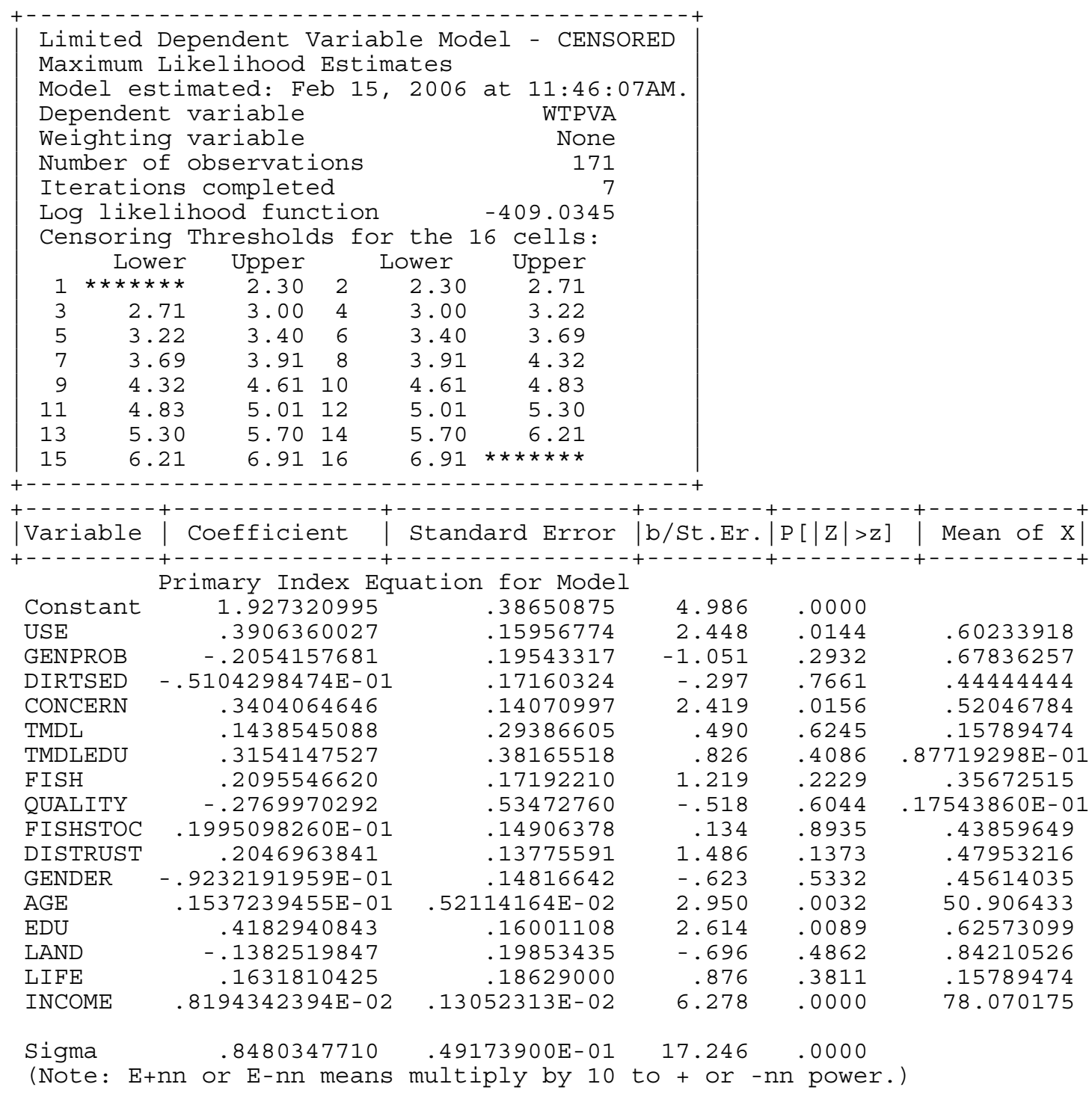

Matrix: La

$[18,4]$ 


\section{A.3.4 Virginia Riparian Landowner WTP for In-State Clean-up Final Results.}

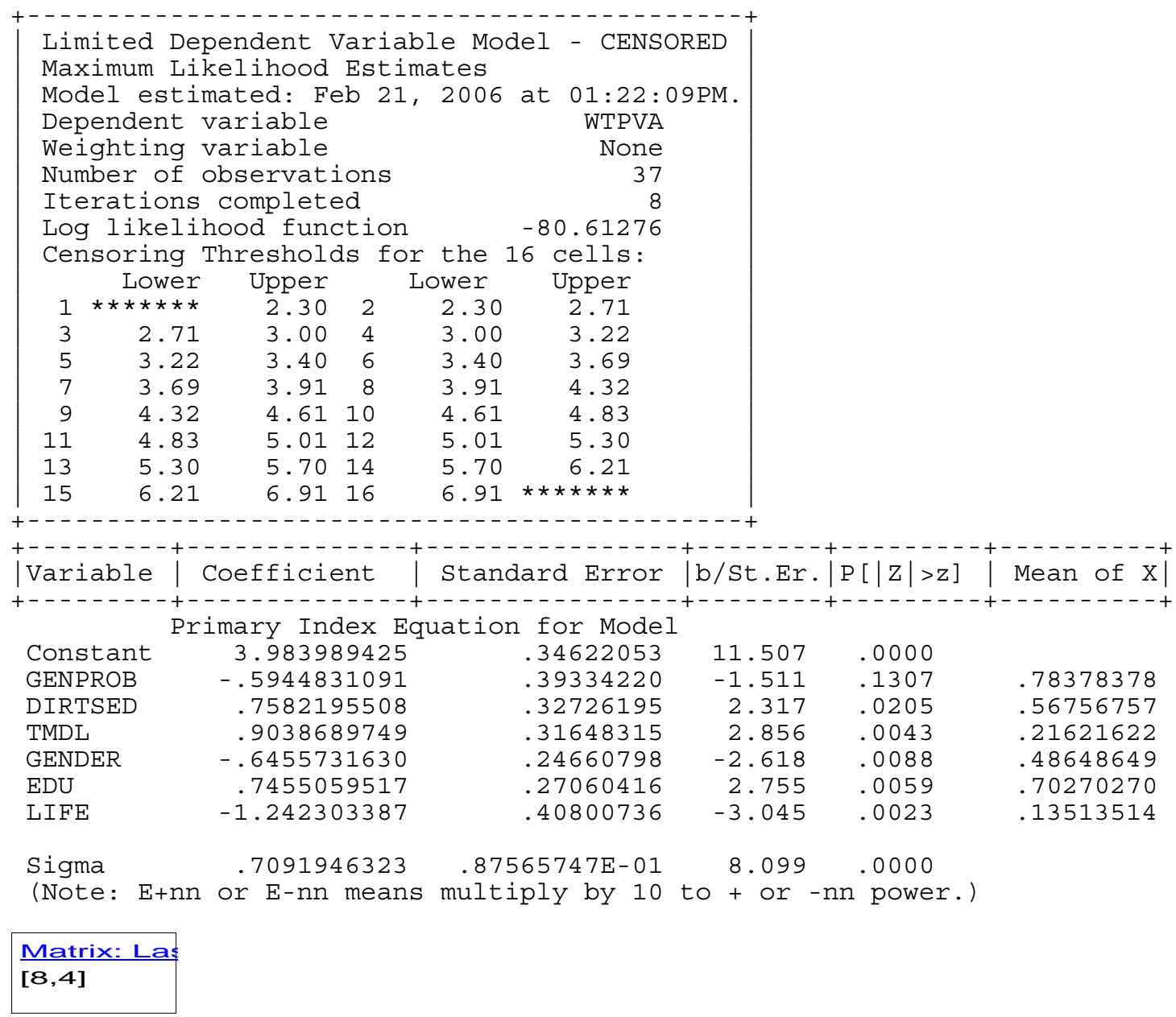




\section{A.3.5 West Virginia General Public WTP for In-State Clean-up Final Results.}

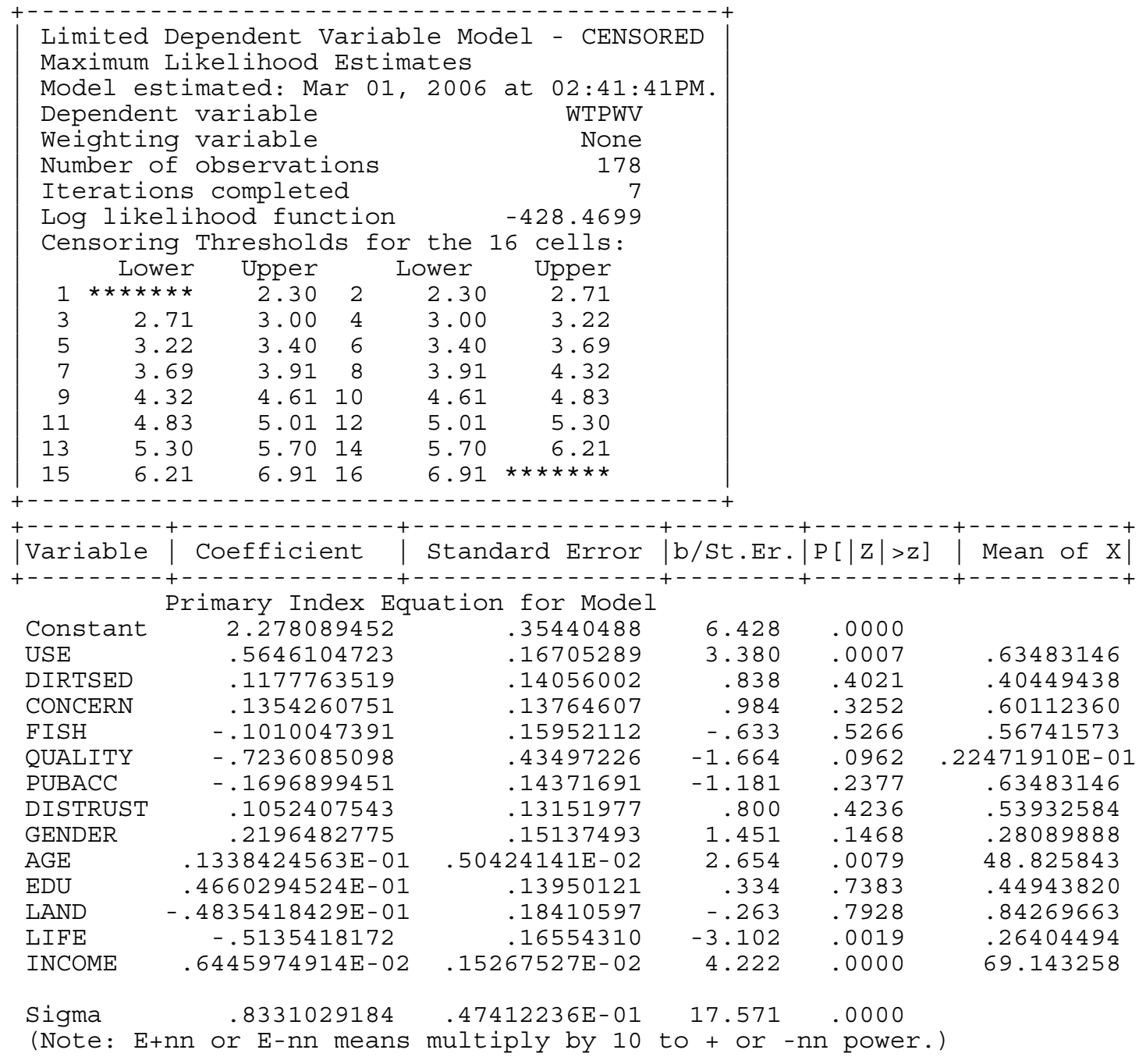

Matrix: La

$[15,4]$ 


\section{A.3.6 Comparing Sub-Samples: West Virginia General Public (WVGP) and Virginia General Public (VAGP) WTP for Out-of-State Clean-up.}

\section{WVGP Results:}

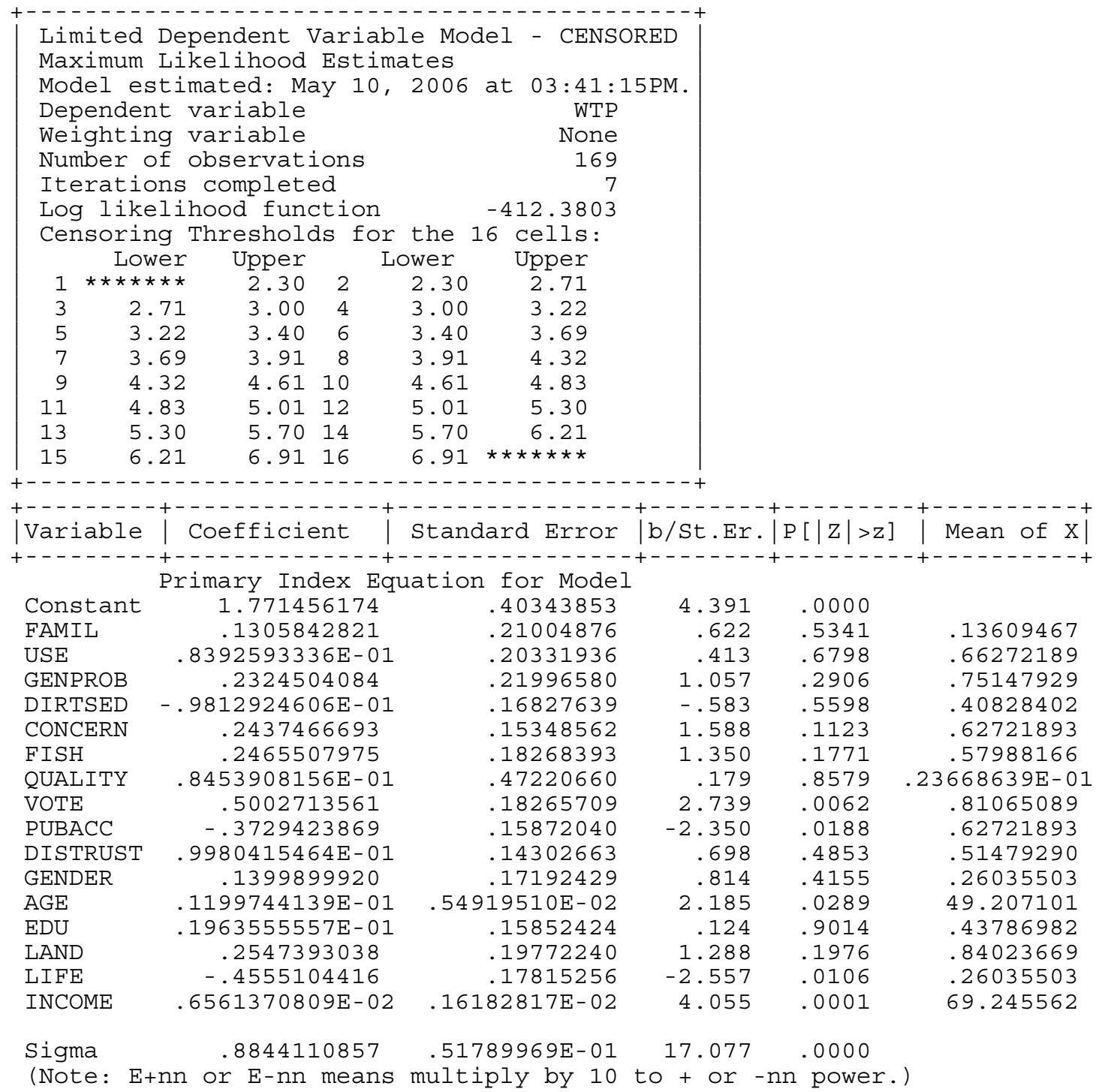




\section{VAGP Results:}

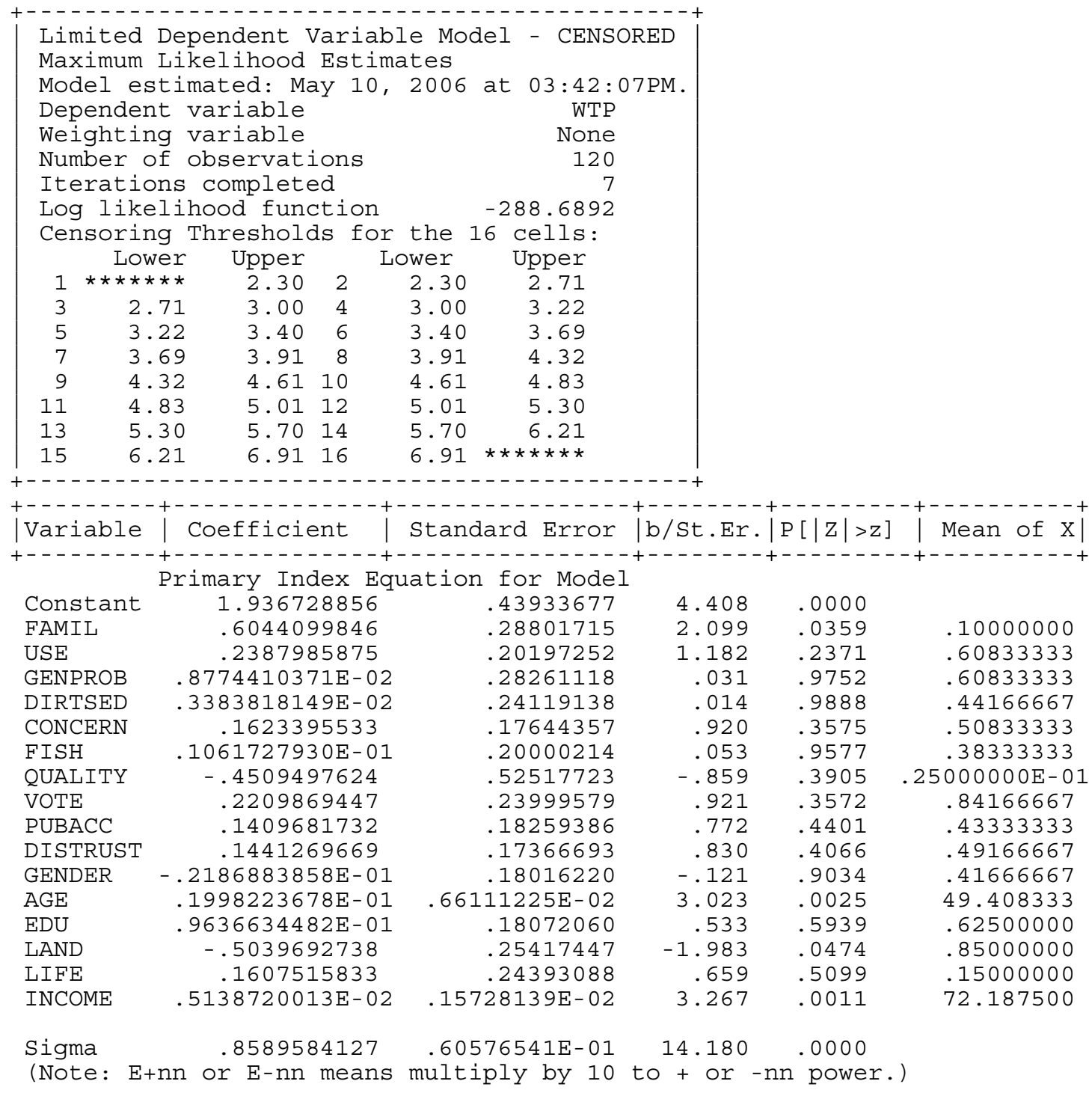

Matrix: La

$[18,4]$ 


\section{Pooled (WVGP+VAGP) Results:}

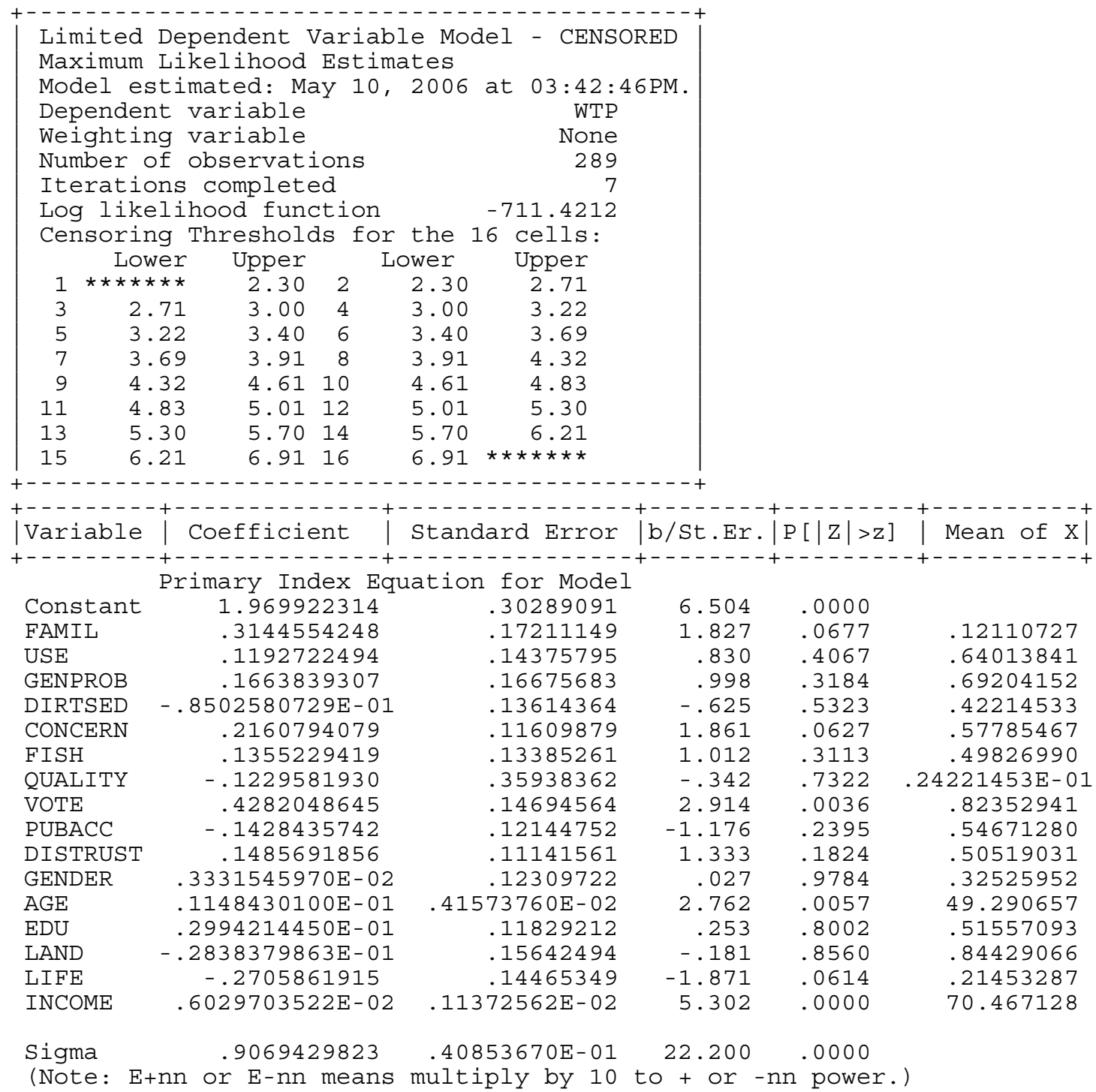

Matrix: Las

$[18,4]$ 


\section{A.3.7 Pooled General Public WTP for Out-of-State Clean-up Final Results.}

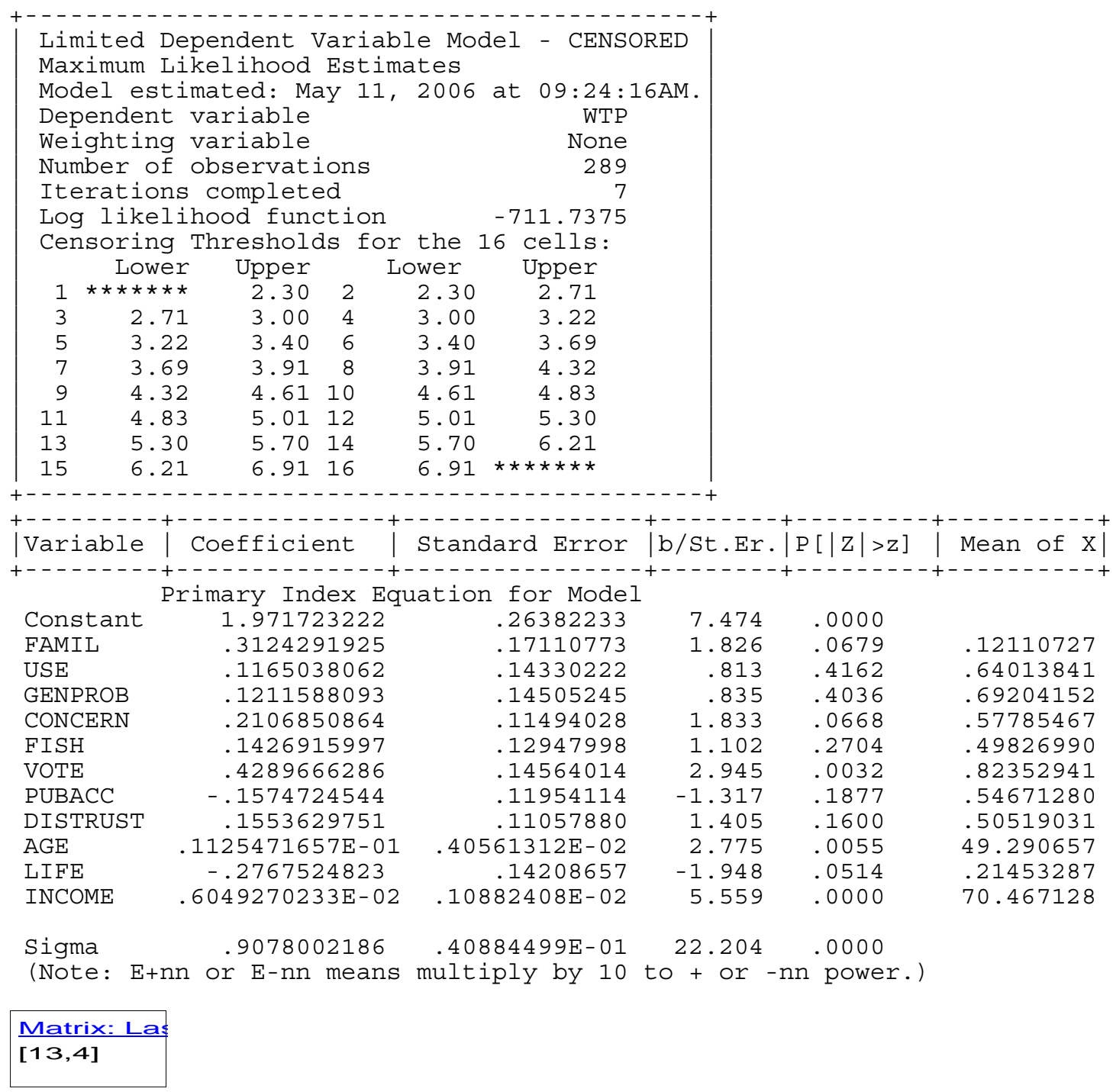




\section{A.4 Total WTP (Benefit) Estimates.}

Table A.4.1- Summary of High Scenario Total WTP Estimates.

\begin{tabular}{|l|c|c|c|}
\hline Sub-sample & $\begin{array}{c}\text { In-State } \\
(\approx \$ \text { million })\end{array}$ & $\begin{array}{c}\text { Out-of-State } \\
(\approx \$ \text { million })\end{array}$ & $\begin{array}{c}\text { Total } \\
(\approx \$ \text { million })\end{array}$ \\
\hline West Virginia general public & $2.49-3.59$ & 0.41 & $2.90-4.00$ \\
\hline Virginia general public & $3.00-4.31$ & 0.33 & $3.33-4.64$ \\
\hline Virginia Riparian landowners & $0.08-0.11$ & 0.03 & $0.11-0.14$ \\
\hline Total & $5.57-8.01$ & 0.77 & $6.34-8.78$ \\
\hline
\end{tabular}

Table A.4.2- Summary of Medium Scenario Total WTP Estimates.

\begin{tabular}{|l|c|c|c|}
\hline Sub-sample & $\begin{array}{c}\text { In-State } \\
(\approx \$ \text { million })\end{array}$ & $\begin{array}{c}\text { Out-of-State } \\
(\approx \$ \text { million })\end{array}$ & $\begin{array}{c}\text { Total } \\
(\approx \$ \text { million })\end{array}$ \\
\hline West Virginia general public & $1.50-2.16$ & 0.29 & $1.79-2.45$ \\
\hline Virginia general public & $1.63-2.35$ & 0.18 & $1.81-2.53$ \\
\hline Virginia Riparian landowners & $0.08-0.11$ & 0.03 & $0.11-0.14$ \\
\hline Total & $3.21-4.62$ & 0.50 & $3.71-5.12$ \\
\hline
\end{tabular}

Table A.4.3- Summary of Low Scenario Total WTP Estimates.

\begin{tabular}{|l|c|c|c|}
\hline Sub-sample & $\begin{array}{c}\text { In-State } \\
(\approx \$ \text { million })\end{array}$ & $\begin{array}{c}\text { Out-of-State } \\
(\approx \$ \text { million })\end{array}$ & $\begin{array}{c}\text { Total } \\
(\approx \$ \text { million })\end{array}$ \\
\hline West Virginia general public & $0.32-0.47$ & 0.05 & $0.37-0.52$ \\
\hline Virginia general public & $0.30-0.43$ & 0.03 & $0.33-0.46$ \\
\hline Virginia Riparian landowners & $0.08-0.11$ & 0.00 & $0.08-0.11$ \\
\hline Total & $0.70-1.0$ & 0.08 & $0.78-1.09$ \\
\hline
\end{tabular}

